\title{
Decontamination And \\ Decommissioning
}

\author{
G. A. Adams \\ W.C.Bowen \\ P. M. Cromer \\ J.C. Cwynar \\ W.R. Jacoby \\ H.G. Woodsum
}

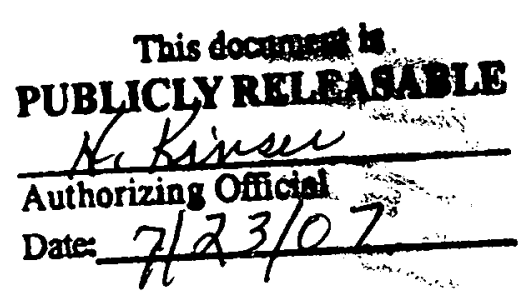

Approved By:
J.S. Theilacker

Prepared for the U.S. Department of Energy

Contract: DE-AC02-80ET37247

February 1982

WESTINGHOUSE ELECTRIC CORPORATIÓN

Advanced Reactors Division

P.O. Box 158

Madison, Pennsylvania 15663 


\section{DISCLAIMER}

This report was prepared as an account of work sponsored by an agency of the United States Government. Neither the United States Government nor any agency Thereof, nor any of their employees, makes any warranty, express or implied, or assumes any legal liability or responsibility for the accuracy, completeness, or usefulness of any information, apparatus, product, or process disclosed, or represents that its use would not infringe privately owned rights. Reference herein to any specific commercial product, process, or service by trade name, trademark, manufacturer, or otherwise does not necessarily constitute or imply its endorsement, recommendation, or favoring by the United States Government or any agency thereof. The views and opinions of authors expressed herein do not necessarily state or reflect those of the United States Government or any agency thereof. 


\section{DISCLAIMER}

Portions of this document may be illegible in electronic image products. Images are produced from the best available original document. 


\section{DISCLAIMER}

This report was prepared as an account of work sponsored by an agency of the United States Government. Neither the United States Government nor any agency thereof, nor any of their employees, makes any warranty, express or implied, or assumes any legal liability or responsiblity for the accuracy, completeness, or usefulness of any information, apparatus, product, or process disclosed, or represents that its use would not infringe privately owned rights. Reference herein to any specific commercial product, process, or service by trade name, trademark, manufacturer, or otherwise, does not necessarily constitute or imply its endorsement, recommendation, or favoring by the United States Government or any agency thereof. The views and opinions of authors expressed herein do not necessarily state or reflect those of the United States Government or any agency thereof.

Printed in the United States of America Available from

National Technical Information Service

U.S. Department of Commerce 5285 Port Royal Road Springfield, VA 22161

NTIS price codes

Printed copy:

Microfiche copy: A01 
TABLE OF CONTENTS

Section

Title

Page

TABLE OF CONTENTS

$-i-$

LIST OF FIGURES

$-i j i-$

LIST OF TABLES

$-v-$

LIST OF ATTACHMENTS

$-v i-$

LIST OF ACRONYMS

-vii-

1.0 SITE/FACILITY DESCRIPTION

$1-1$

1.1 BACKGROUND

1.2 SITE LOCATION AND LAYOUT

$1-1$

$1-3$

2.0

PROJECT SUMMARY

$2-1$

2.1 PROJECT OBJECTIVE

2-1

2.2 PROJECT PLANNING

$2-3$

2.3 PROJECT OPERATIONS

$2-6$

2.4 SPECIAL PROBLEMS AND SOLUTIONS

$2-24$

2.4.1 PROBLEM NO. 1 - CHANGE IN POSITION ON 2-24 SHORING OF CONTAINERS FOR BURIAL

2.4.2 PROBLEM NO. 2 - REMOVAL OF SUPER TIGERS FROM 2-30 SERVICE

2.5 WASTE MANAGEMENT

2-39

2.5.1 GENERAL

2.5.2 TRU WASTE

2.5.3 NONTRU WASTE

$2-39$

$2-39$

$2-47$

2.5.4 CLEAN WASTE

$2-48$

2.6 RADIATION EXPOSURE OF PERSONNEL

2.6.1 PERSONNEL EXPOSURE TO EXTERNAL RADIATION

$2-49$

$2-57$

2.6.2 PERSONNEL EXPOSURE TO INTERNAL RADIATION

2.6.3 PERSONNEL EXPOSURE ESTIMATES

$2-60$

2.6.4 STACK EFFLUENT DISCHARGES AND EXPOSURE OF

2-61 OFF-SITE INDIVIDUALS

3.0

PROJECT COST AND SCHEDULE

$3-1$

3.1 BACKGROUND

$3-1$

3.2 INITIAL COST

$3-2$

3.3 INITIAL SCHEDULE

3.4 MODIFICATIONS TO SCOPE OF WORK AND SCHEDULE

3.5 FINAL ESTIMATED COST ANO SCHEDULE

3-3

$3-6$

3-7 
TABLE OF CONTENTS (Continued)

Section

Title

$\underline{\text { Page }}$

4.0 FINAL SITE CONDITION

4-1

4.1 CRITERIA

4-1

4.2 FINAL CONDITION

4-1

4.2.1 GENERAL DESCRIPTION OF METHODS

4-1

4.2.1.1 DETAILED RESULTS OF BUILDING 8

4-3

4.2.1.2 DETAILED RESULTS OF BUILDING 7 SURVEYS

5.0 CONCLUSIONS AND RECOMMENDATIONS

$5-1$

5.1 CONCLUSIONS

5.2 RECOMMENDATIONS

$5-1$

$5-1$

APPENDICES:

A SUMMARY OF PROCEDURES AND DATA FORMS FOR THE MITS

B MANUFACTURING AND INSPECTION TRAVELERS (MITS)

$A-1$

B-1 


\section{LIST OF FIGURES}

\begin{tabular}{|c|c|c|}
\hline Figure & Title & Page \\
\hline $1-1$ & General Site Location & $1-3$ \\
\hline $1-2$ & Cheswick Site Location & $1-4$ \\
\hline $1-3$ & Photograph of Advanced Fuels Laboratory (8uilding 8) & $1-4$ \\
\hline $1-4$ & Contour Map of the Site Area & $1-5$ \\
\hline $1-5$ & Building 7 Floor Plan & $1-6$ \\
\hline $1-6$ & PFDL (Building 8) Floor Plan & $1-7$ \\
\hline $1-7$ & $\begin{array}{l}\text { Interior Walls to be Decontaminated in Plutonium } \\
\text { Laboratory (Building 7) }\end{array}$ & $1-8$ \\
\hline $1-8$ & $\begin{array}{l}\text { Interior Walls to be Decontaminated in Plutonium } \\
\text { Laboratory (Building } 8 \text { ) }\end{array}$ & $1-9$ \\
\hline $2-1$ & $\begin{array}{l}\text { Process Flow Chart for Packaging/Shipping Transuranic } \\
\text { Waste (i.e., Glove Boxes) in FRP Plywood Boxes }\end{array}$ & $2-3$ \\
\hline $2-2$ & $\begin{array}{l}\text { Process Flow Chart for Packaging/Shipping Transuranic } \\
\text { Waste in DOT } 17 \mathrm{C} \text { Steel Drums }\end{array}$ & $<-4$ \\
\hline $2-3$ & $\begin{array}{l}\text { Revised Process Flow Chart for Packaging/Shipping } \\
\text { Transuranic Waste in DOT } 17 \mathrm{C} \text { Steel Drums }\end{array}$ & $2-4$ \\
\hline $2-4$ & $\begin{array}{l}\text { Process Flow Chart for Packaging/Shipping Transuranic } \\
\text { Waste in DOT Spec } 7 \text { A Steel Boxes (ANL M-III B in) }\end{array}$ & $2-5$ \\
\hline $2-5$ & $\begin{array}{l}\text { Process Flow Chart for Packaging/Shipping } \\
\text { Non-Transuranic Waste in DOT SpeC } 7 \text { A Steel Boxes } \\
\text { (ANL-M-III Bin) }\end{array}$ & $2-5$ \\
\hline $2-6$ & $\begin{array}{l}\text { Loading of M-III Bins with Radioactive Waste at ARD } \\
\text { Fuel Laboratories at Cheswick }\end{array}$ & $2-11$ \\
\hline $2-7$ & Loading the M-III Bins into the Poly Panther Overpack & $2-15$ \\
\hline $2-8$ & Loading of Glove Box and Application of Foam & $2-17$ \\
\hline $2-9$ & $\begin{array}{l}\text { Sequence of Operations Prior to Completing FRP for } \\
\text { Shipment }\end{array}$ & $2-19$ \\
\hline $2-10$ & FRP Loading and Super Tiger Closure Operations & $2-21$ \\
\hline $2-11$ & $\begin{array}{l}\text { Waste Management Scheme for D\&D Program at ARD } \\
\text { Plutonium Labs }\end{array}$ & $2-40$ \\
\hline
\end{tabular}


LIST OF FIGURES (Continued)

Figure

$3-1$

$3-2$

4-1

4-2

4-3

$4-4$

4-5

4-6

4-7

4-8

4-9

$4-10$

4-11
Title

Page

Summary Schedule of Phases for Conducting D\&D Program

3-4

3-5

4-3

Location of Survey Areas on Floor of ARD Plutonium Lab, Building 8

Location of Survey Areas on North Wall of ARD Plutonium Lab, Building 8

Location of Survey Areas on West Wall of ARD Plutonium Lab, Building 8

Location of Survey Areas on Ceiling of ARD Plutonium Lab, Building 8

Location of Survey Areas on East and South Wall Areas of ARD Plutonium Lab, Building 8

Location for Determining Removable Alpha Activity Within a 1-Square-Meter Grid

Sketch of Roof Area Grid with Designed Smear Locations for Survey in Building 7 Plutonium Lab

$4-13$

$4-14$

Plutonium Lab

Location of Designated Grids on Floor and Inside

$4-75$

Surface of Roof, Building 7 Plutonium Lab

Location of Designated Grids on All Surfaces of

Visitors Entrances and Vault Peripheral Service Areas

$4-16$

for Building 7 Plutonium Lab Final Survey

Location of Designated Grids on All Surfaces of Lavatory and Rear Air Lock Entrance Peripheral Service Areas for Building 7 Plutonium Lab 


\section{LIST OF TABLES}

Table

Title

$\underline{\text { Page }}$

$2-1$

Summary of M-III Bin Shipments in Poly Panther Type B Overpack

2-2 Summary of Dimensions, Volume and Weight for FRP

2-3 Cost Comparison of Drum Shipments: Super Tiger Vs Poly Panther

2-4 Summary of Drum Shipments in Poly Panther Type B Overpack

Summary of FPR Shipments in Super Tiger Type B Overpack

$2-38$

$2-6$

Summary of All TRU Waste Shipments Made to DOE Richland

$2-46$ Burial Site

2-7 Radiation Exposure History Comparison of SNM-1120 to All Facilities

$2-8$

External Radiation Exposure for Operating Personnel

$2-51$ SNM-1120 Operations

$2-9$

Summary of Principal Operations

$2-53$

$2-10$

Breakdown of Total Man-Rem Radiation Exposure by Job Functions

Radiation Exposure History

$2-56$

$2-12$

Summary of Air Samples > Action Level for SNM-1120

$2-58$ Operations

Summary of Air Sample > MPC for SNM-1120 Operations 


\section{LIST OF ATTACHMENTS}

Attachment

Title

Plan for Fully Decontaminating and Decommissioning of the Westinghouse ARD Fuel Laboratories at Cheswick

Environmental Assessment for Decontaminating and

Decommissioning the Westinghouse Advanced Reactors Division

Plutonium Fuel Laboratories, Cheswick, PA

WARD-386, Quality Assurance Program Description for Decontamination and Decommissioning Activities

Heaith Physics, Fire Control, and Site Emergency Manual

Detailed Working Documents Utilized in Decontamination and Decommissioning of the Westinghouse ARD Fuel Laboratories at Cheswick

Specification E-955048; Coating with Fiberglass Reinforced Res in

Drawing 1620E43, Sub. 3; Design of Strong Wooden Box Coated with Fiberglass Reinforced Resin for Shipping and Burial of Contaminated Glove Boxes

Analys is of Design - Strong Wooden Box Coated with Fiberglass Reinforced Resin for Shipping and Burial of Contaminated Glove Boxes

Procedure PFDL-AP-0013 - Procedure for Disposition of Potentially (TRU) Contaminated Materials from Buildings 7 and 3 


\section{LIST OF ACRONYMS}

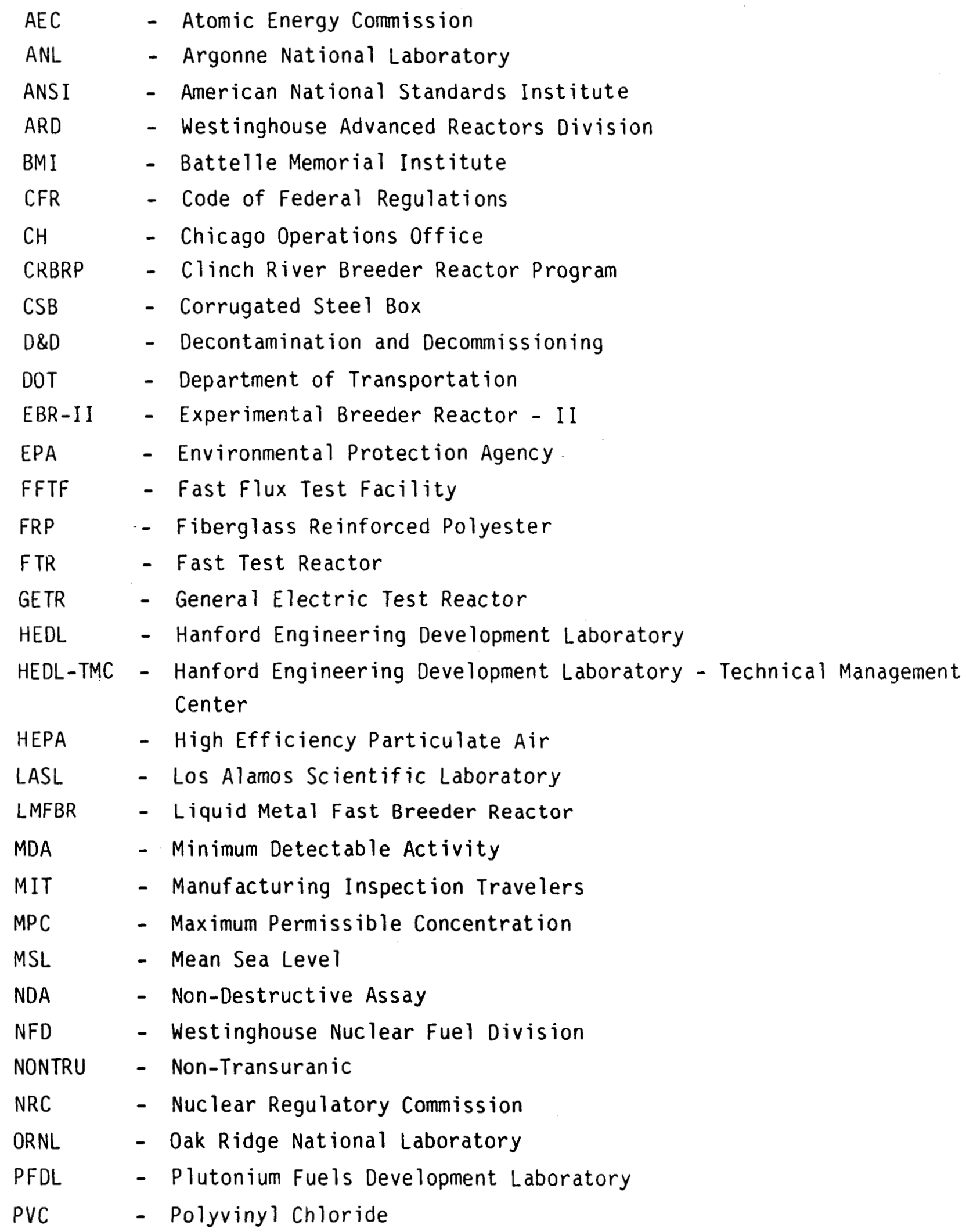




\section{LIST OF ACRONYMS (Continued)}

RHO

- Rockwell Hanford Operations

ROO

- Richland Operations Office

SNM

- Special Nuclear Materials

SSNM

- Strategic Special Nuclear Materials

SST

- Safe, Secure Transport

TLD

- Thermoluminescent Dosimeter

TRU

- Transuranic

UNI

- United Nuclear Industries 


\subsection{SITE/FACILITY DESCRIPTION}

\subsection{BACKGROUND}

The Westinghouse Advanced Reactors Division (ARD) operated two nuclear fuel laboratories at the Cheswick Site located in Harmar Township in Allegheny County near Pittsburgh, PA. These facilities, known as ARD Fuel Laboratories, consisted of the Plutonium Laboratory (Building 7 ) and the Advanced Fuels Laboratory (Building 8).

These operations complemented the Plutonium Fuels Development Laboratory (PFDL), which was operated by the Westinghouse Nuclear Fuels Division (NFD) for development and fabrication of Light Water Recycle Fuel. Not only was the site shared, but buildings, analytical services, license administration, safeguard compliances, security, health physics monitoring and many other day-to-day operating requirements of a laboratory operated for utilization and recycling of plutonium (either in a pressurized water reactor or in a fast breeder nuclear power plant) were also shared.

The Plutonium Laboratory was established in 1966 for process and fabrication development and characterization of mixed uranium-plutonium carbide fuel materials and fuel elements. Sodium-bonded fuel pins were fabricated under Government contract from 1967 to 1969 for irradiation testing in the General Electric Test Reactor (GETR) and in Experimental Breeder Reactor-II (EBR-II).

Stemming from a 1969 AEC decision to decrease and phase out Government support of carbide fuel for the Liquid Metal Fast Breeder Reactor (LMFBR) applications and to emphasize oxide fuel for the Fast Flux Test Facility (FFTF) and the Clinch River Breeder Reactor Plant (CRBRP), an Oxide Fabrication Line was established in Building 8. Initially, this facility was designed to operate with a once-through air atmosphere in the glove boxes, but later provisions were made for conversion to an inert atmosphere in the glove boxes, if required. A significant number of uranium, plutonium oxide fuel assemblies were fabricated in this facility under Government contracts from 1969 to 1973 for irradiation testing in EBR-II. 
ARD became a participant in the LMFBR Advanced Fuels Program in 1974. Extensive facility modifications were made primarily in the Building 8 fabrication area to facilitate fabrication of the uranium, plutonium carbide material. Following these modifications, approximately 250 fuel pins containing uranium, plutonium carbide fuel were fabricated for testing in EBR-II from 1974 through 1979. During this period, continued facility modifications were directed at increasing throughput and providing a capability for fabricating the longer Fast Test Reactor (FTR) type pins. With increased throughput and longer pin capability, fabrication of fuel pins of FTR assemblies became possible. Fabrication of an initial complement of pins $(A C N-1)$ for testing in FTR was completed toward the end of this time period.

In addition, a separate fuel fabrication facility also had been established for fabricating blanket fuel rods. During the last two years of operation, sufficient blanket rods for five assemblies had been fabricated--two assemblies for testing in EBR-II, and three for testing in FTR. 


\subsection{SITE LOCATION AND LAYOUT}

The Cheswick Site is located in the southwest section of Pennsylvania in Allegheny County. It is approximately ten miles northeast of Pittsburgh and is easily reached by the Pennsylvania Turnpike, Route 76 as shown in Figure 1-1. Nearby towns, industrial plants, public facilities, the Allegheny River,

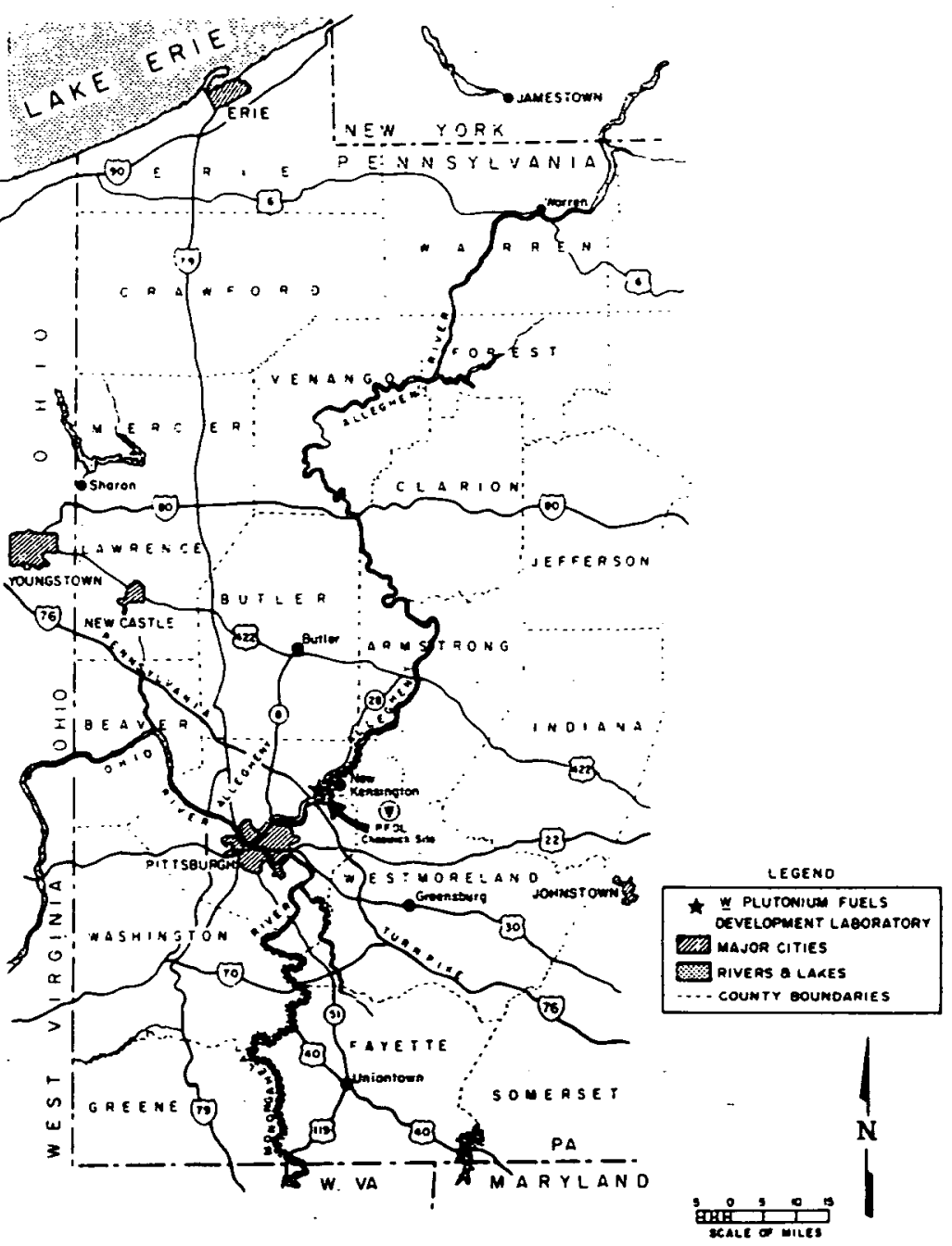

Figure 1-1. General Site Location

$6604-41$

and transportation links are shown in Figure 1-2. The Site is bounded by the Cheswick and Harmar Railroad to the north and west, and by Low Grade Road to the east and the borough of Acmetonia to the South. 


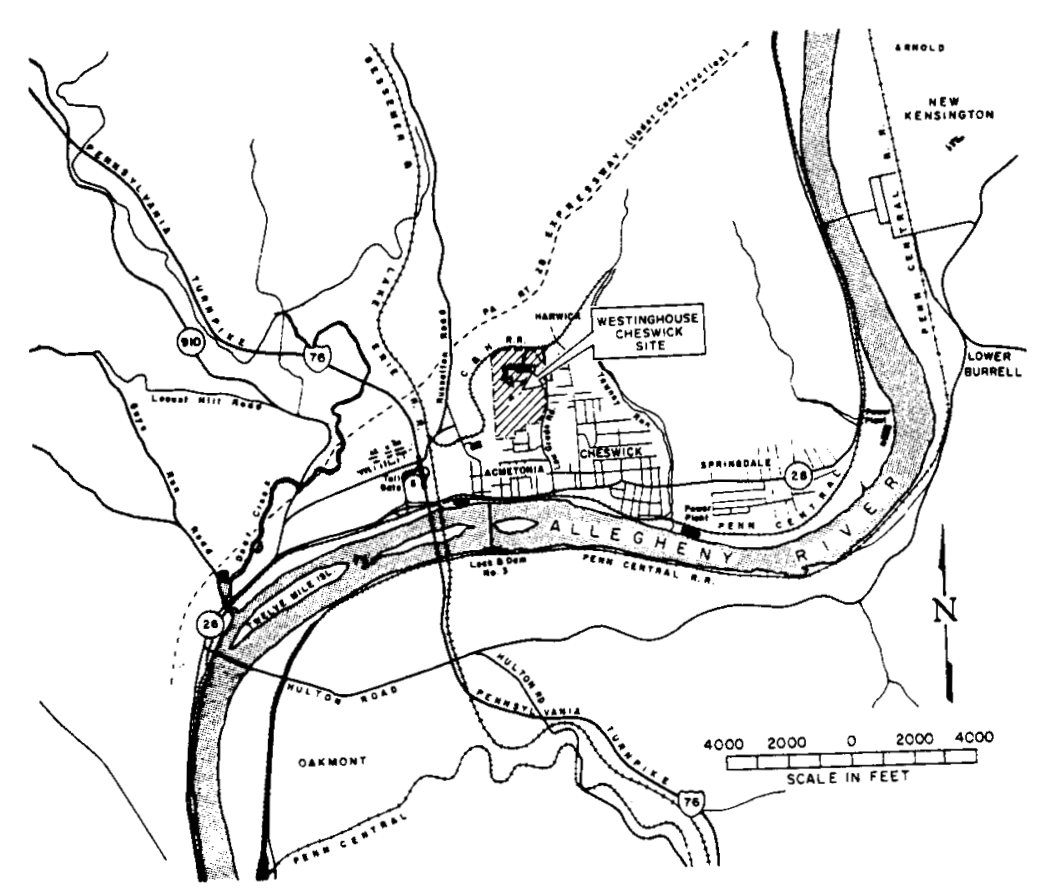

Figure 1-2. Cheswick Site Location

6604.40

The Plutonium Laboratory (Building 7) and the Advanced Fuel Laboratory (Building 8) are located in the center of approximately 113 acres of existing, disturbed commercial land at 960 feet above mean sea level (MSL). Figure 1-3 is a photograph of the Advanced Fuel Laboratory and Figure 1-4 is a contour map of the Site which shows the Building 8 perimeter and exclusion area

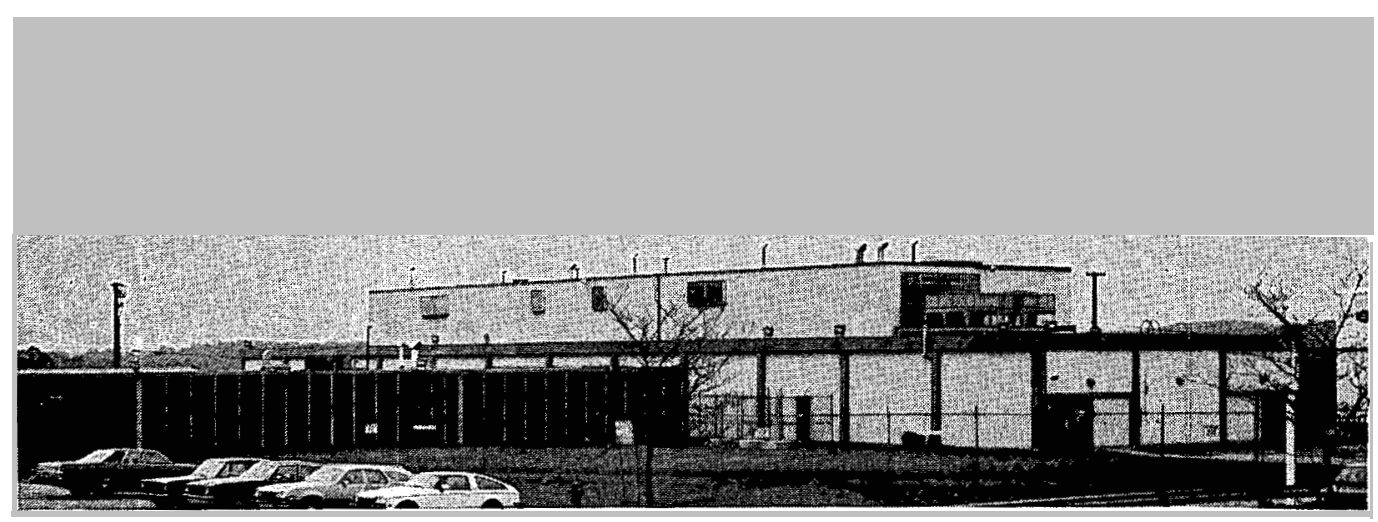

Figure 1-3. Photograph of the Advanced Fuels Laboratory (Building 8) 
boundary. Figure 1-5 shows a floor plan of Building 7 with ARD occupied areas and fenceline exclusion area boundaries. Figure 1-6 shows a similar floor plan for Building 8 with ARD occupied areas noted. Figures $1-7$ and 1-8 show areas that were decontaminated. Prior to decommissioning, the buildings were maintained and fully operable.

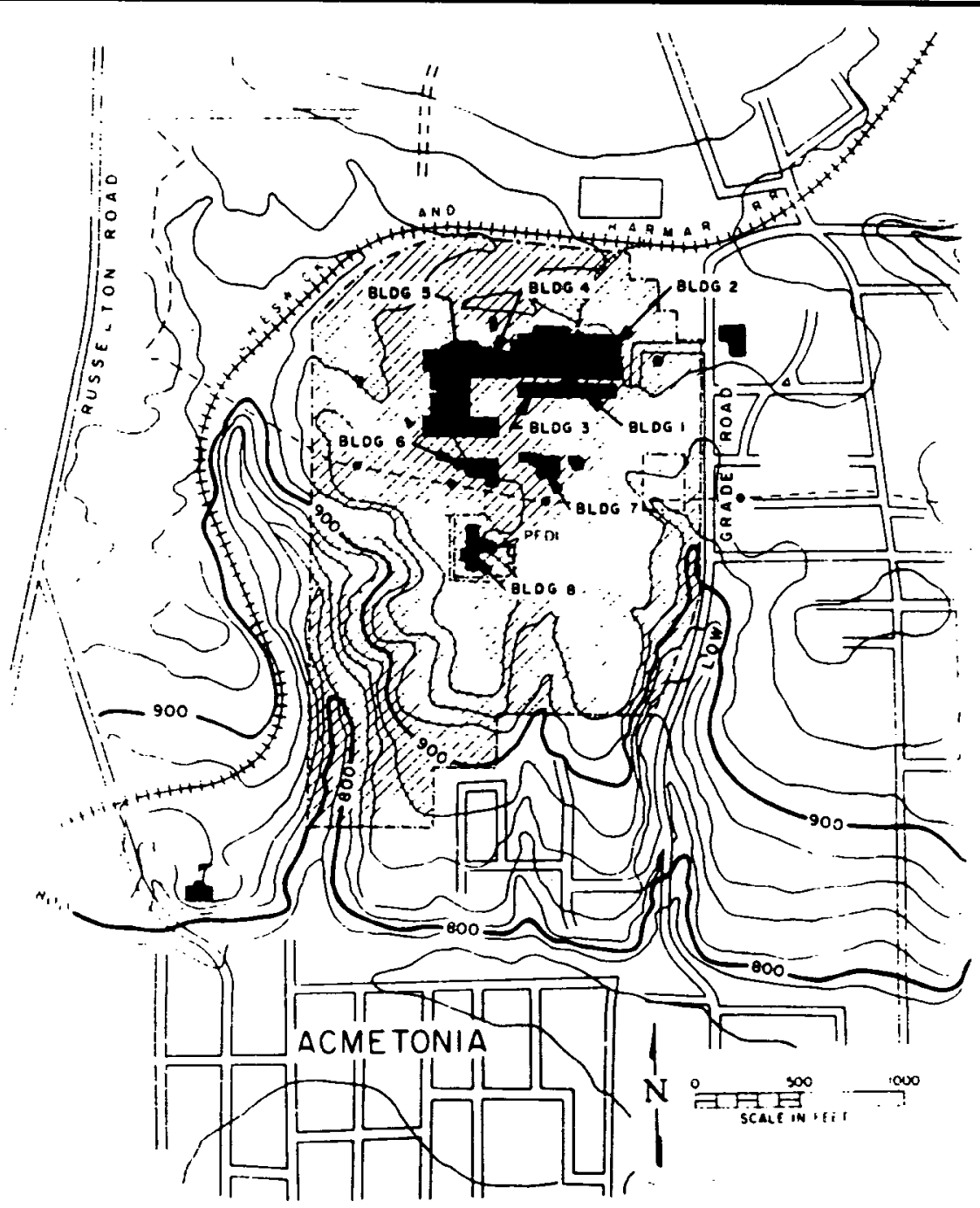

Figure 14. Contour Map of the Site Area 


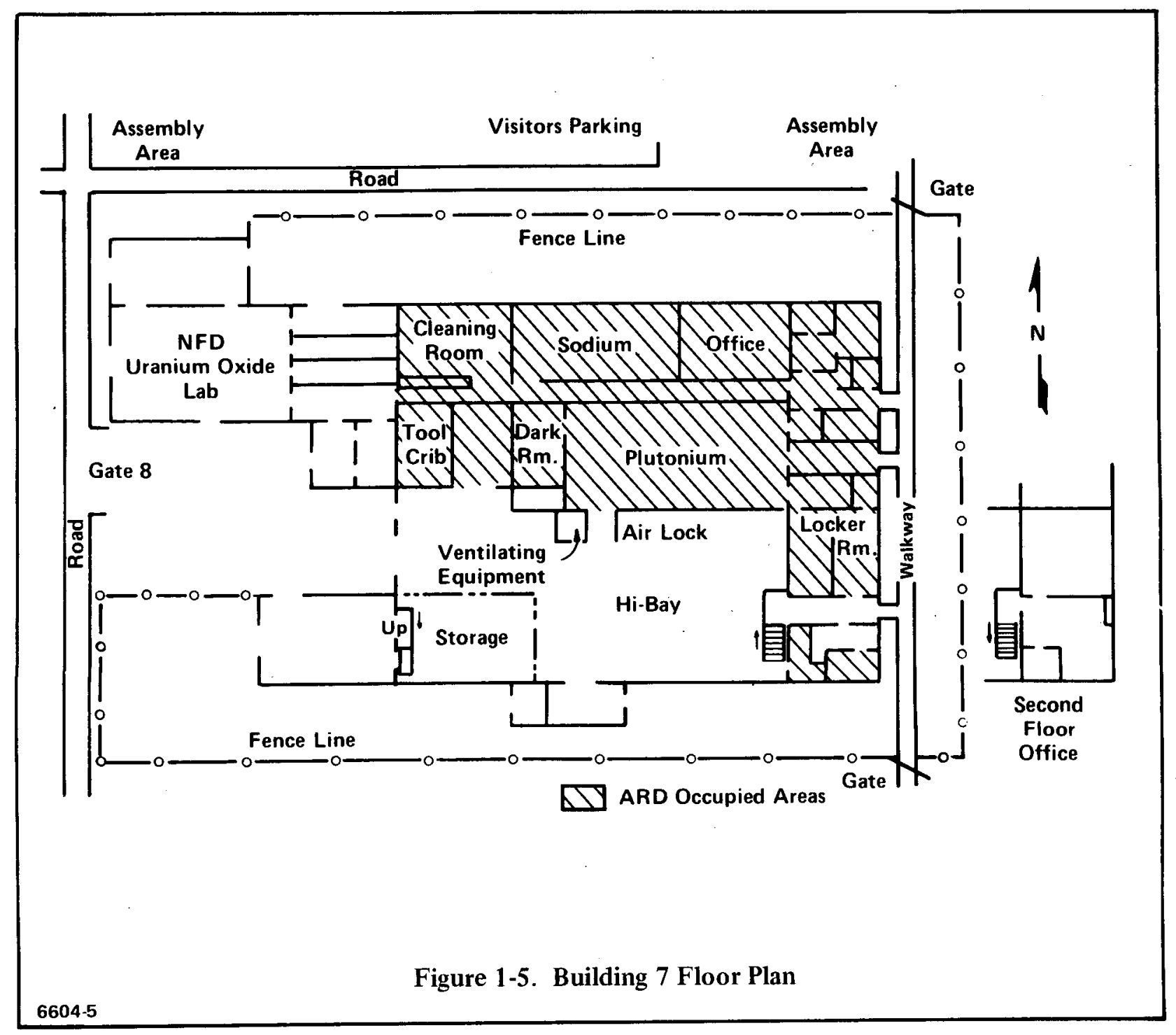




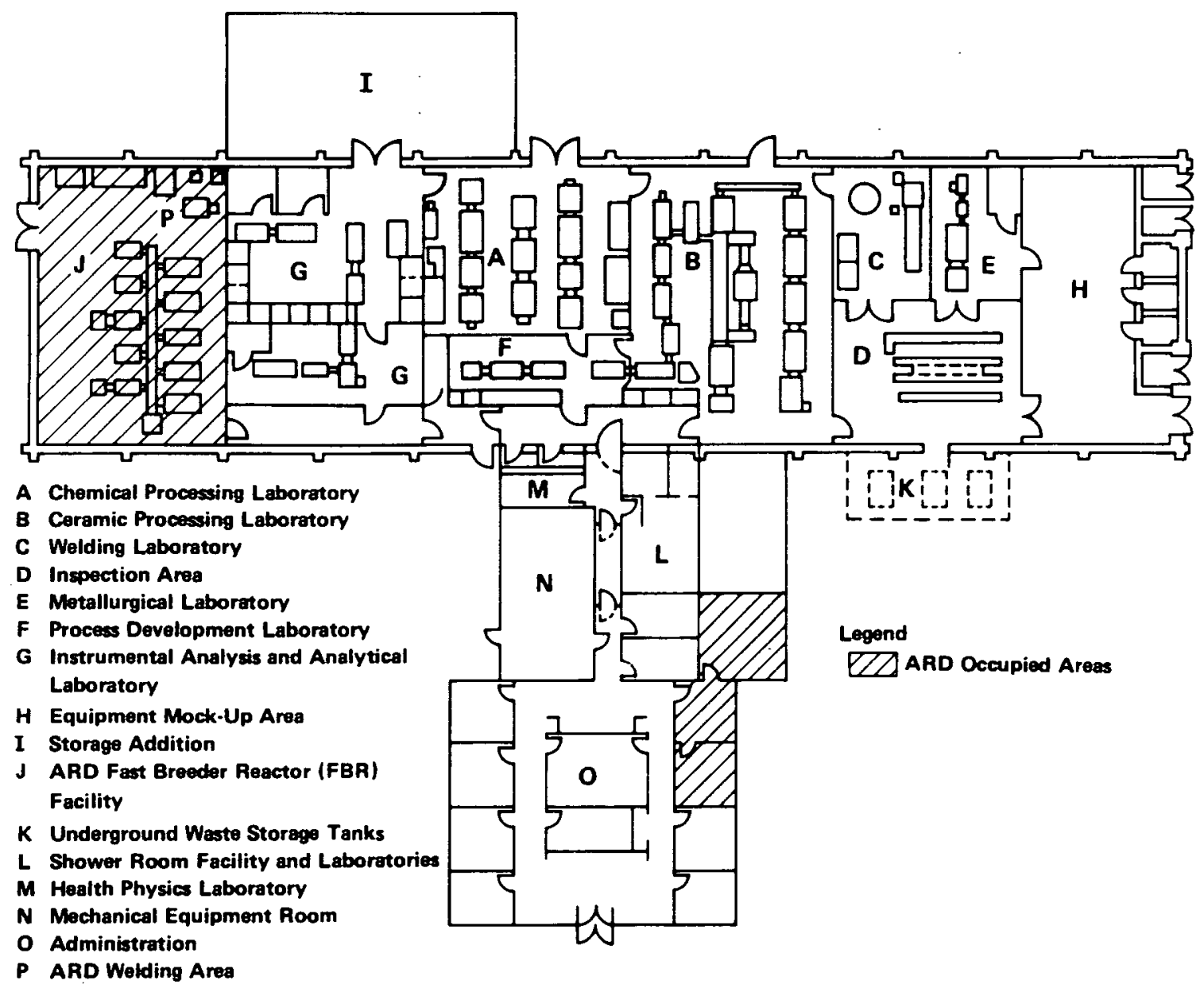

Figure 1-6. PFDL (Building 8) Floor Plan 


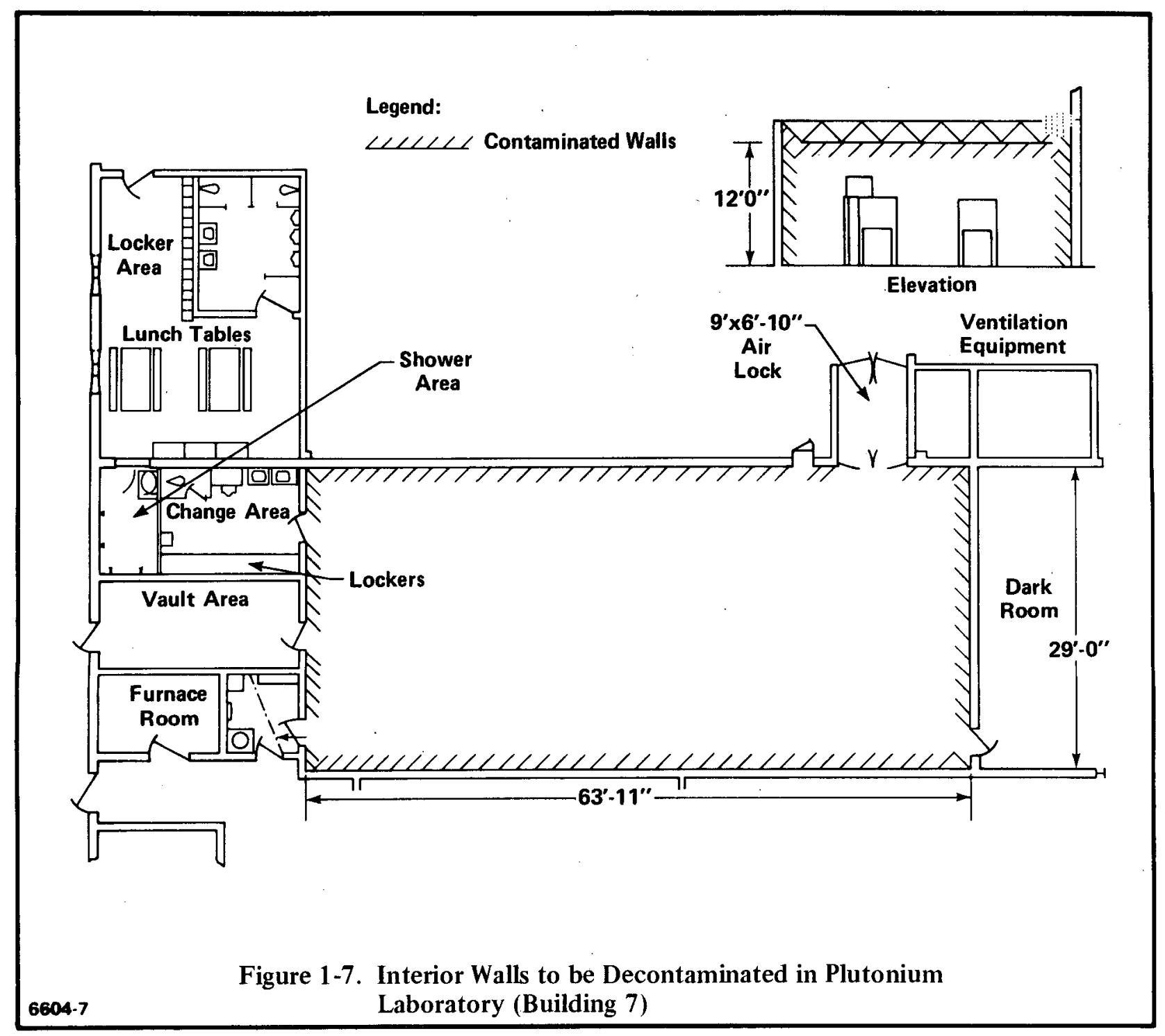




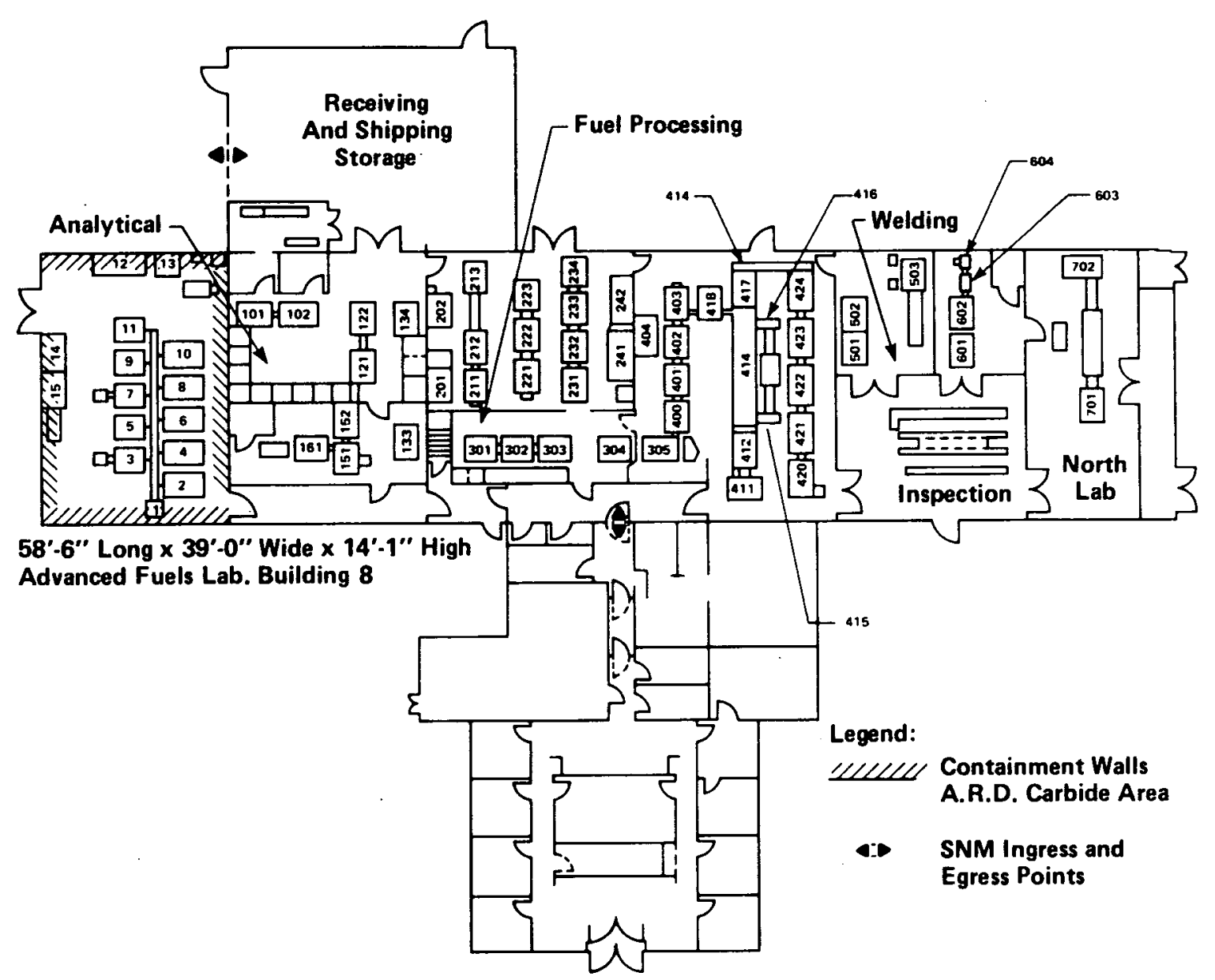

$6604-8$

Figure 1-8. Interior Walls to be Decontaminated in Plutonium Laboratory (Building 8) 


\subsection{PROJECT SUMMARY}

\subsection{PROJECT OBJECTIVE}

The project scope of work included the complete decontamination and decommissioning (D\&D) of the Westinghouse ARD Fuel Laboratories at the Cheswick Site in the shortest possible time. This has been accomplished in the following four phases:

\section{PHASE 1}

Preparation of documents and necessary paperwork

Packaging and shipping of all special nuclear materials in an acceptable form to a reprocessing agency

PHASE 2

Decontamination of all facilities, glove boxes and equipment Loading of generated waste into bins, barrels and strong wooden boxes

\section{PHASE 3}

Shipping of all bins, barrels and boxes containing waste to the designated burial site

Removal of all utility services from the laboratories

\section{PHASE 4}

Final survey of remaining facilities and certification for nonrestricted use

Preparation of final report 
These four phases of work were conducted in accordance with applicable regulations for D\&D of research facilities and applicable regulations for packaging, transportation, and burial and storage of radioactive materials. The final result is that the Advanced Fuel Laboratories now meet requirements of ANSI 13.12 and can be released for unrestricted use.

At present, the contract with $\mathrm{DOE} / \mathrm{CH}$ includes Phase 5 , which is Westinghouse ARD's prorated share for D\&D of the Chemistry Laboratory (shared during operations with another Westinghouse Division). However, this report only addresses Phases 1 through 4. The Phase 5 D\&D effort will be discussed in a separate report. 


\subsection{PROJECT PLANNING}

The four principal documents utilized in the $0 \& 0$ of the Cheswick Site were: (1) Plan for Fully Decontaminating and Decommissioning, Revision 3;

(2) Environmental Assessment for Decontaminating and Decommissioning the Westinghouse Advanced Reactors Division Plutonium Fuel Laboratories, Cheswick, Pa.; (3) WARD-386, Quality Assurance Program Description for Decontaminating and Decommissioning Activities; and (4) Health Physics, Fire Control, and Site Emergency Manual. These documents are provided as Attachments 1, 2, 3 and 4.

Day-to-day work was controlled by a system of detailed procedures and documents. Figures 2-1 through 2-5 are flowcharts depicting the sequence of Manufacturing Inspection Travelers (MIT) (route cards) for carrying out the work. In addition, Appendix A contains tables that summarize the procedures and data forms referenced on each MIT. Appendix B contains a list of all of the detailed working documents according to type in numerical order. Copies are provided in Attachment 5 .

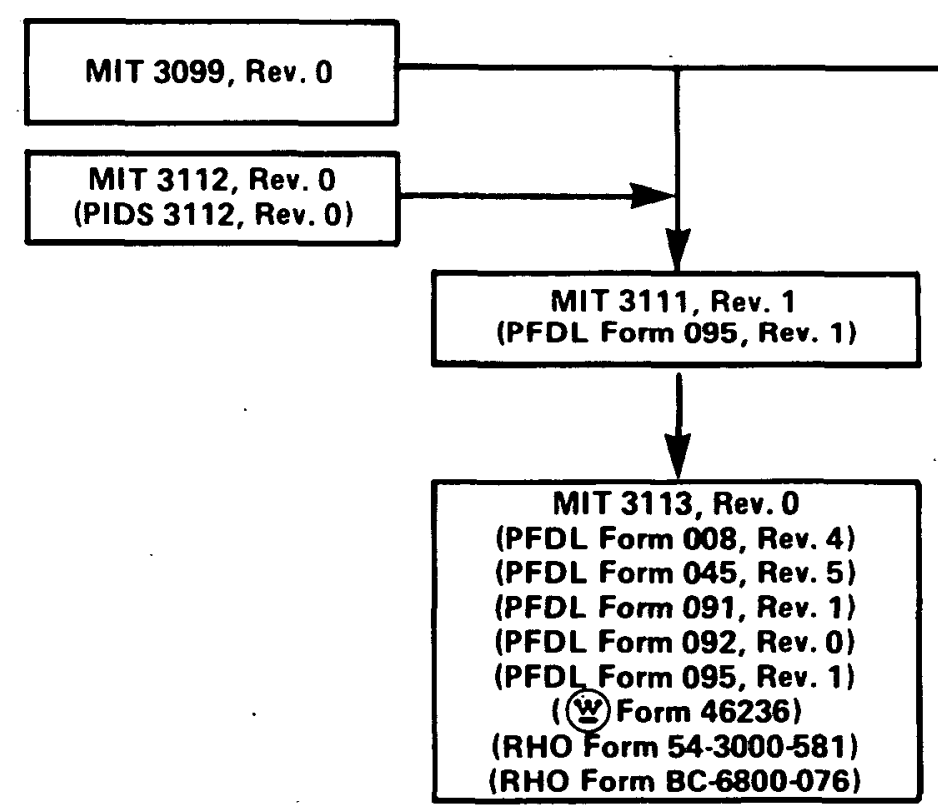

Figure 2-1. Process Flow Chart for Packaging/Shipping Transuranic Waste (i.e. Glove Boxes) in 6604.9 FRP Plywood Boxes 

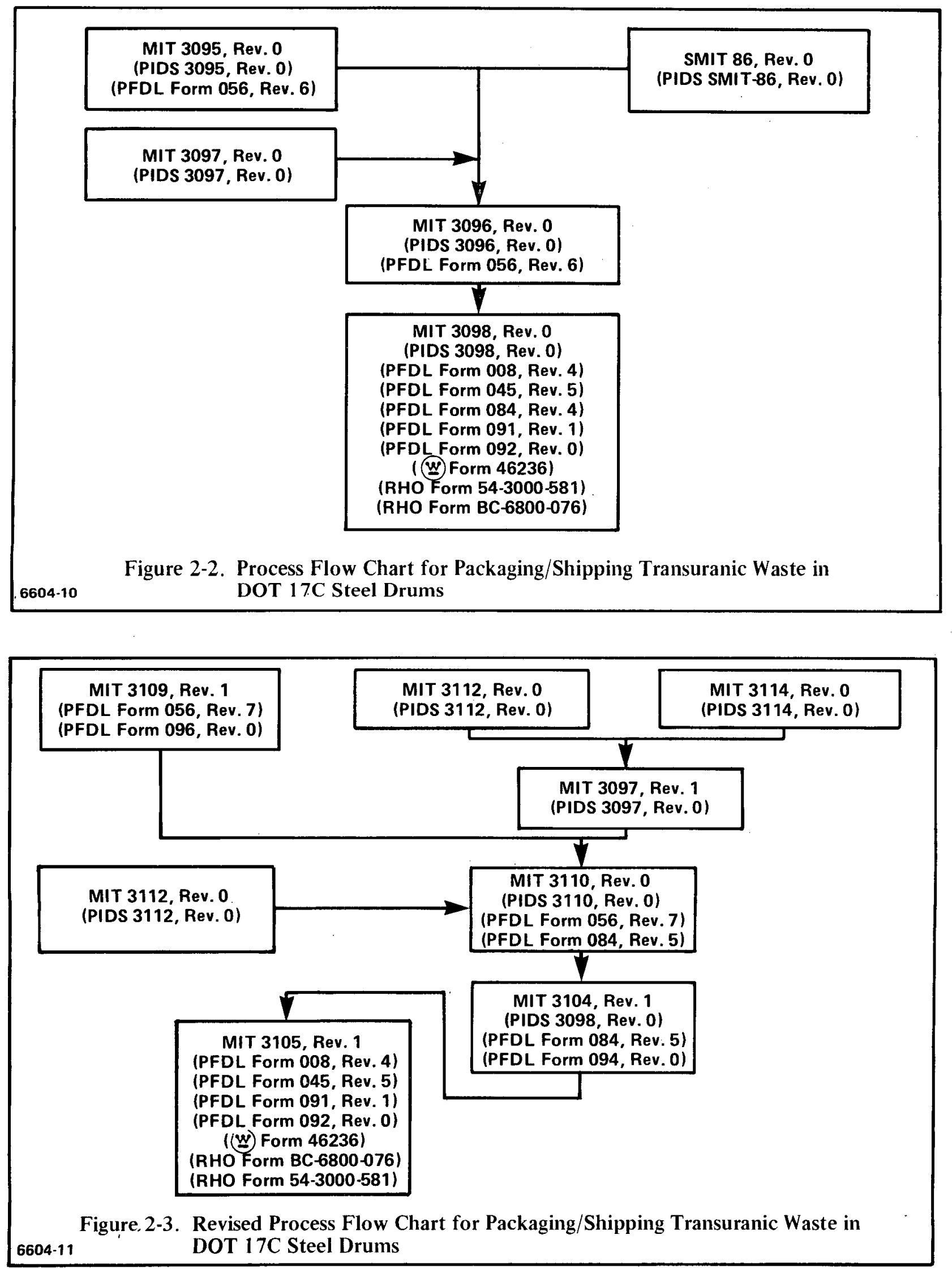


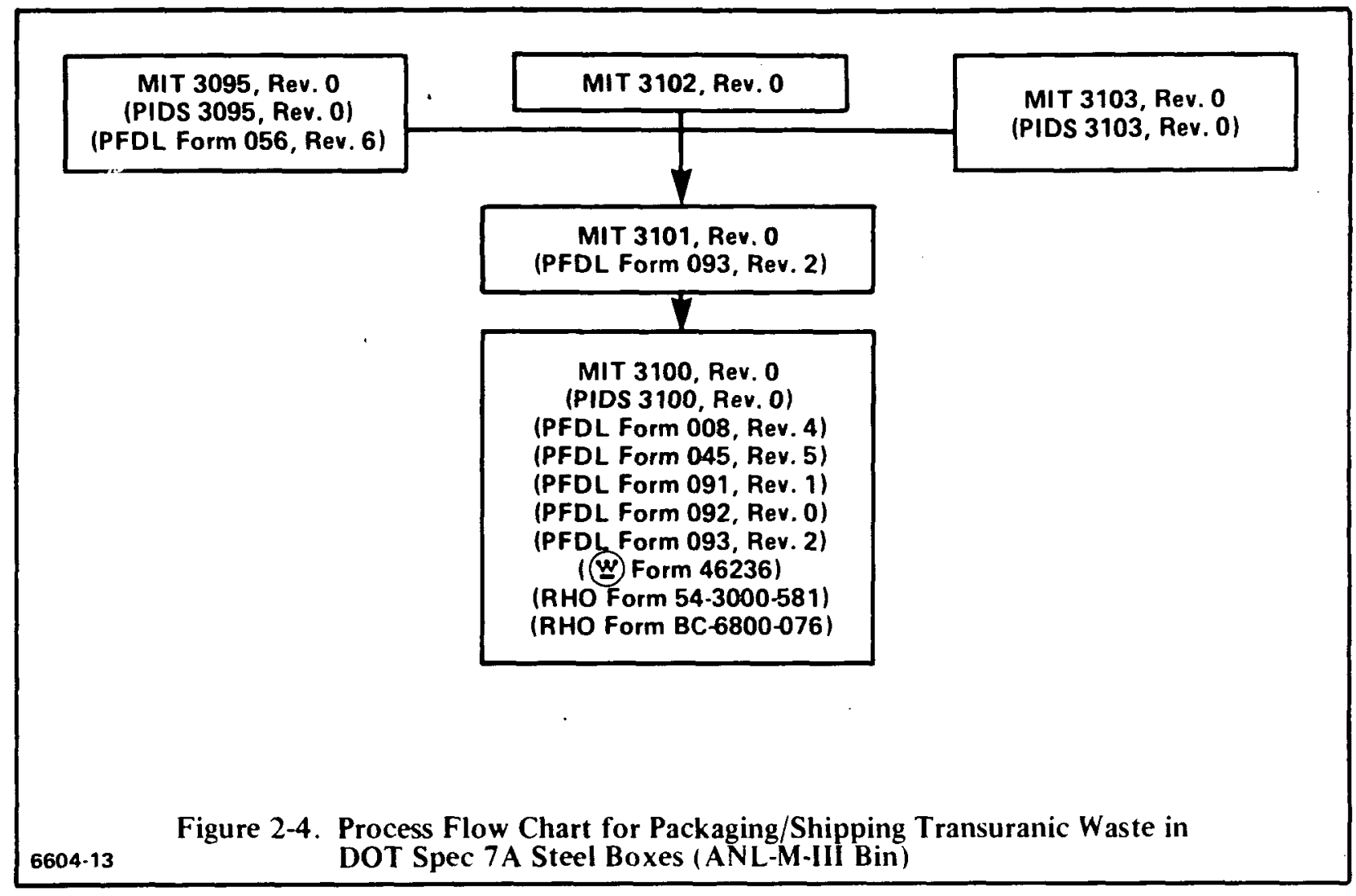

* Procedure Modified for LSA

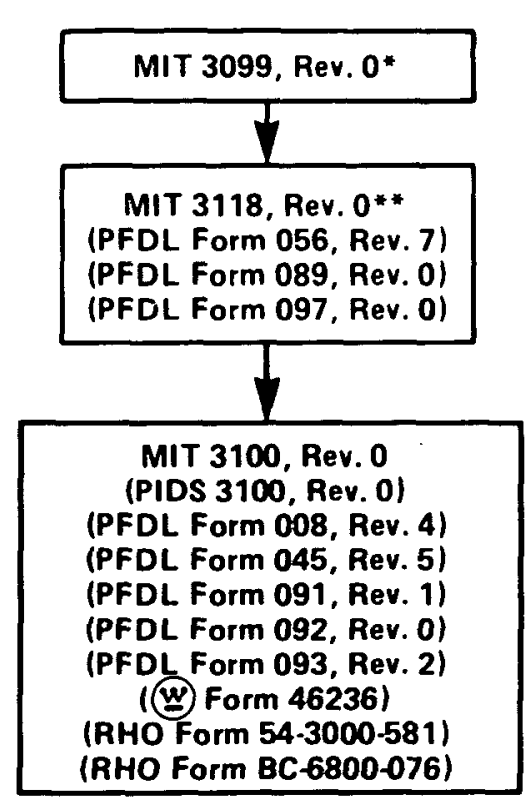

* * Procedures Modified for M-III Bins

Figure 2-5. Process Flow Chart for Packaging/Shipping Non-Transuranic Waste in DOT Spec 7A Steel Boxes (ANL-M-III Bin) 


\subsection{OPERATIONS}

$D \& D$ operations were conducted in accordance with the tasks defined in the D\&D plan.

The first major effort (under Task 1) was the identification, consolidation, sampling, packaging and shipping off-site of the then current inventory of strategic special nuclear materials (SSNM). Initially, this was a high priority effort since security requirements of the operating license were commensurate with the quantity of SSNM, both allowed and possessed. A prompt reduction in SSNM inventory, and therefore security requirements, waS essential to the cost effectiveness of the $0 \& 0$ effort.

The fuel materials were in the following forms: (1) Virgin $\mathrm{PuO}_{2}$ and enriched $\mathrm{UO}_{2}$ powders, (2) scrap (U,Pu) $0_{2}$ powders, (3) scrap $(U, P U) C$ pellets, and $(4)(U, P u) O_{2}$ and $(U, P u) C$ pellets contained in welded fuel rods being stored as archive/replacement rods in accordance with the appropriate irradiation test program specification.

Virgin $\mathrm{PuO}_{2}$ and $\mathrm{UO}_{2}$ powders and $\operatorname{scrap}(\mathrm{U}, \mathrm{Pu}) \mathrm{O}_{2}$ powders required only sampling and repackaging prior to shipment while the $(U, P U) C$ pellets required oxidizing to convert them to $(U, P u) 0_{2}$ powder prior to sampling and packaging. The rods containing mixed oxide fuel were packaged and shipped to Hanford Engineering Development Laboratory (HEDL), and the rods containing mixed carbide fuel were packaged and shipped to Los Alamos Scientific Laboratory (LASL). The virgin $\mathrm{PuO}_{2}$ was shipped to $\mathrm{HEDL}$, virgin enriched $\mathrm{UO}_{2}$. was shipped to Oak Ridge National Laboratory (ORNL), and scrap mixed oxide was shipped to Rockwell Hanford Operations (RHO) for interim storage. All powder shipments were made in Model $\mathrm{FL}-10-1$ shipping containers and transported by the DOE Safe, Secure Transport (SST) vehicle.

Upon completion of the packaging of the SSNM, efforts were directed (under Task 2) to the removal and disposal of non-contaminated equipment and furniture from both laboratories. Items such as controllers, atmosphere 
analyzers, instrumentation, tables, and cabinets were wiped down, surveyed, smeared, and upon release by Health Physics, were normally dispositioned as excess property.

In conjunction with the previously described work, equipment, tools, fixtures and supplies small enough to pass through the 8 -inch bag port were disassembled, wiped with oiled paper cloths, and removed from each glove box by the bag-out procedure. Larger equipment items such as hand hydraulic presses, ball mills, drying ovens, balances, and centerless grinders were brushed, wiped, and disassembled into component parts for removal via the larger bag ports ( 18 or 24 inch). The automatic pellet press in glove box 6 (Building 8) was disassembled sufficiently to allow all components to be bagged out, but the base plate from the centerless grinder in glove box 9 (Building 8) was left in the box for later removal through a window opening after decontaminating and fixing the base plate and box interior.

The waste packages (double-bagged, contaminated items) were labeled for traceability and waste type, and placed into temporary Department of Transportation (DOT) Spec 17C, 55 gallon galvanized drums. Items too large to $f$ it into drums were placed in plywood boxes constructed on-site for this purpose. All waste packages were assayed for contained special nuclear materials by gamma scanning before loading into the final shipping containers.

The argon purification units, which had been used to maintain the high quality argon atmospheres $\left(50 \mathrm{ppm} \mathrm{O}_{2} ; 10 \mathrm{ppm} \mathrm{\textrm {H } _ { 2 }}\right.$ ) in the glove boxes during fuel processing operations, were disconnected from the glove boxes as soon as practical. The boxes were then operated on once-through-air with High Efficiency Particulate Air (HEPA) filtered inlets drawing in laboratory air with outlets discharging into the glove box ventilation system. The argon purification units were double-bagged (wrapped) in 0.012 inch thick polyvinylchloride (PVC) and stored until assaying operations were performed. The nitrogen removal units on glove boxes 14 and 15 (rod loading and end plug welding boxes, Building 8) were disconnected, wrapped, stored and assayed in similar fashion. 
Piping and wiring supply services not required for decontamination operations (such as recirculating cooling water for furnaces and atmosphere purifiers, argon, helium, air, oxygen and moisture detectors, furnace power supplies, controllers, and vacuum systems) were surveyed, disconnected, double-bagged if contaminated, assayed and placed in wooden boxes. All service lines, which were directly or indirectly connected to glove boxes, were treated and handled as if they were contaminated until proven otherwise. This philosophy did not allow the service removal work to proceed as rapidly as it could have, but it minimized personnel exposure and laboratory contamination risks and eliminated many potential problems throughout the D\&D operations.

Materials, methods and procedures used for decontaminating and final fixing the interior surfaces of glove boxes were established on the basis of the best information available from and recommended by personnel in other organizations engaged in similar work. ARD personnel visited their counterparts at the west Jefferson Laboratories, BMI Columbus, Vallecitos Laboratories, General Electric Company and Pacific Northwest Laboratories and participated in information exchange meetings organized by HEDL-TMC. Various vendors also were contacted for current product information.

Glove box 2 (Building 8), which had been used for weighing, batching and blending of fuel powders, was selected for the development work. A dry brushdown of the disassembled equipment and glove box surfaces was initially performed. Resulting residual powder was placed in a container, combined with brushings from other boxes, sampled and bagged out. All brushings and sweepings of this type were included in the final scrap shipments. Next, the box surfaces, equipment components and box gloves were carefully wiped with oiled, heavy-duty, paper cloths. This operation was repeated until visual evidence of cloth discoloration by powder was no longer apparent. Equipment and components were bagged out of the box. One-half of the glove box was then washed with a detergent-water mixture and dried. The entire box was cleaned with "Nutek $600 \mathrm{EL"} \mathrm{(Nuclear} \mathrm{Technology} \mathrm{Corp.),} \mathrm{a} \mathrm{water} \mathrm{soluble} \mathrm{cleaner} \mathrm{with} \mathrm{a.}$ ph of 7 developed specifically for decontamination. The cleaner diluted 20:1 was applied to the surfaces with a hand-operated plastic spray bottle, and was wiped with heavy-duty, paper cloths. After each cleaning step, $k, \gamma$ readings were taken and an $\sim 1$ foot $^{2}$ area was fixed with "Clear coat" 
(Oakite Co.) a water soluble fixant that is semi-flexible when dry. The fixed areas were smeared and checked for alpha contamination. Various combinations and sequences of wiping, detergent washing, "Nutek" cleaning and "Clear Coat" fixing were applied and evaluated so that an optimized procedure was established. The following operational sequence was utilized for decontaminating the fixing box interiors: (1) dry brush all surfaces and collect residual powder, (2) dry wipe all surfaces with $0 i 1$ impregnated paper cloths; repeat as necessary, (3) apply "Nutek $600 \mathrm{EL}$ " (diluted 20:1 with water) to all surfaces using hand spray bottle and wipe with dry paper cloths, (4) survey surfaces; repeat cleaning step as required, (5) replace gloves with bag "stumps," (6) apply "Clear Coat" fixant using pressure sprayer, (7) survey surfaces for smearable and fixed contamination; repeat fixant application, if necessary.

After the box interiors were decontaminated and fixed, equipment such as sintering, calcining and vacuum furnaces attached to some boxes by " 0 " ring flanges was removed from the box ends and floors under carefully controlled, tented conditions. The openings were sealed with blind flanges fitted with "0" rings. The boxes were disconnected from the exhaust system and the central tunnel, glove ports and bag parts were closed off with protective covers and the boxes were moved to the north laboratory area (Building 8) to await gamma scanning.

Following the disconnection of the glove boxes from the exhaust system and removal from the laboratories, sections of the exhaust system (ridged PVC in Building 8 and galvanized sheet metal in Building 7) were surveyed and removed. The ducting in Building 8 was treated as suspect; however, it was determined to be radiologically clean, section by section, and was disposed of as clean waste material. As the glove boxes were disconnected, the ducting in Building 7 was determined to be contaminated and was sectioned under controlled conditions (localized tenting and respirators) and was disposed of as transuranic (TRU) contaminated waste. As the room ventilation system ducting was disconnected and removed from the laboratories, the same methods and procedures were utilized as for the glove box exhaust system removal and disposition. 
Remaining permanent utility source lines were removed from the rooms and temporary services and mountings were provided for alarms, sensors and lights to facilitate room decontamination and refurbishment.

Final waste packaging (Task 3) was started as soon as the DOT Spec 17C, 55 gallon, galvanized steel drums, Argonne National Laboratory (ANL) M-III bins, and fiberglass reinforced polyester (FRP) resin coated plywood boxes were received, inspected and released for use. See Section 2.5 for detailed waste package descriptions.

In order to satisfy transportation regulations, a minimum thickness of two inches of polyurethane foam between the waste packages and the inner surfaces of the galvanized steel drums in the annular region and of three inches of foam in the ends was provided. This was accomplished by centering a metal mandrel in the drum and forming a foamed-in-place insert in the drum (prefoamed drum). Waste packages were placed into the prefoamed drum, foam was applied among the packages and the final three inches on top was formed. It was originally planned to ship drums in the Model 6400 (Super Tiger) Type B overpack which necessitated that they be foamed; however, the drums were actually shipped in M-III bins contained in the Model 6272 (Poly Panther) Type B overpack.

A pit $6 \mathrm{ft} \times 7 \mathrm{ft} \times 5 \mathrm{ft}$ deep was constructed in the floor of the storage building (Bldg. 8) to facilitate loading drummed, boxed or wrapped large equipment waste into the M-III bins $(4 \mathrm{ft} \times 5 \mathrm{ft} \times 6 \mathrm{ft})$. The bins were placed into the pit and items to be loaded were lowered into the bins from the adjacent working area on the floor. Each M-III bin held eight drums, which were secured by a removable, wedge-type pallet in the center of the bins and polyurethane foam filled PVC bags in the corners. Upon receipt of the Model 6272 (Poly Panther) Overpack at the burial site in Richland, Washington, the drums were removed from the bins, and the bins were returned in the Poly Panther for reloading. Figure 2-6 contains a sequence of photographs depicting loading of M-III bins with radioactive waste at the ARD Fuel Laboratories at Cheswick. 


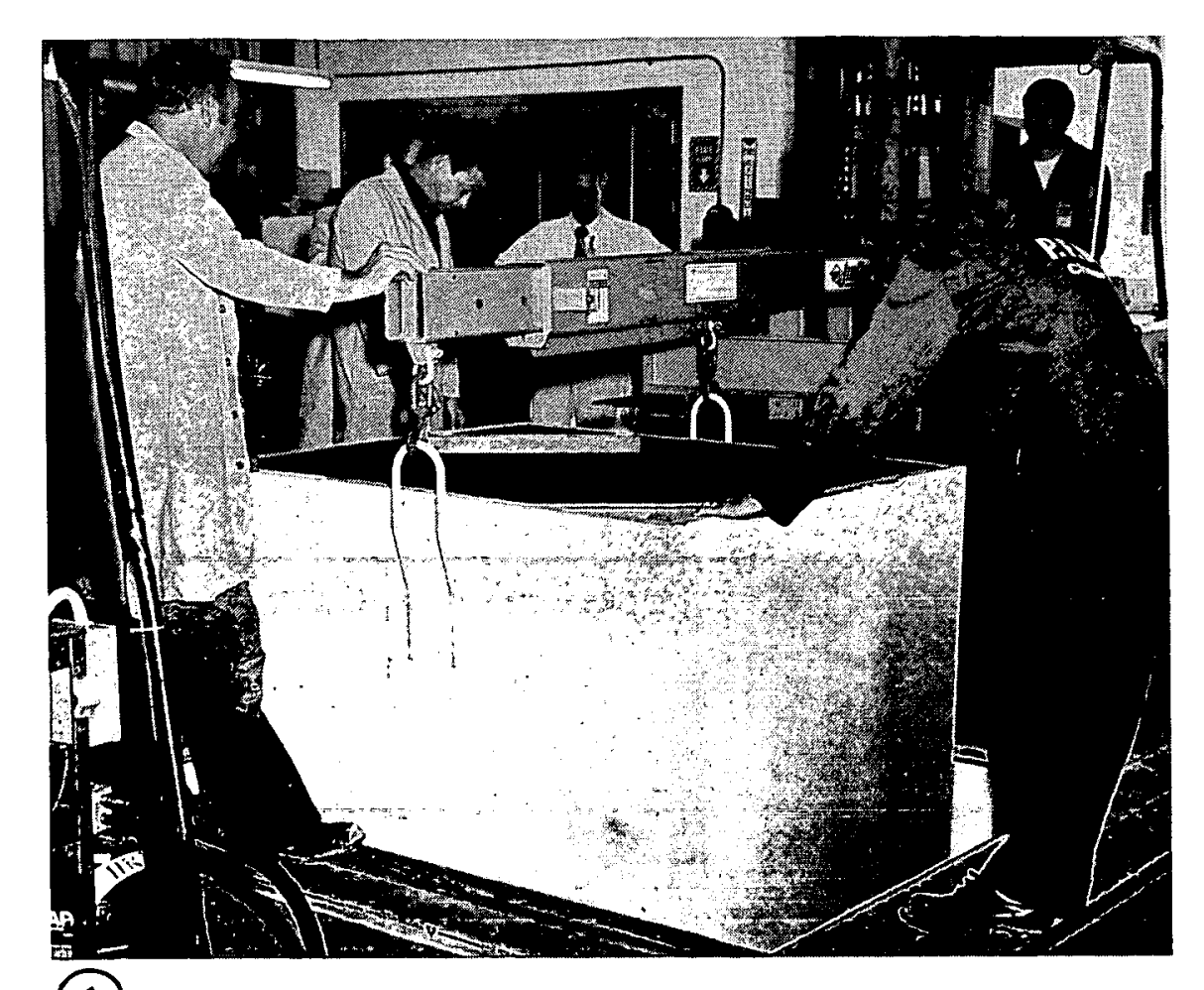

(1) Lowering of M-III Bin into Pit Prior to Loading

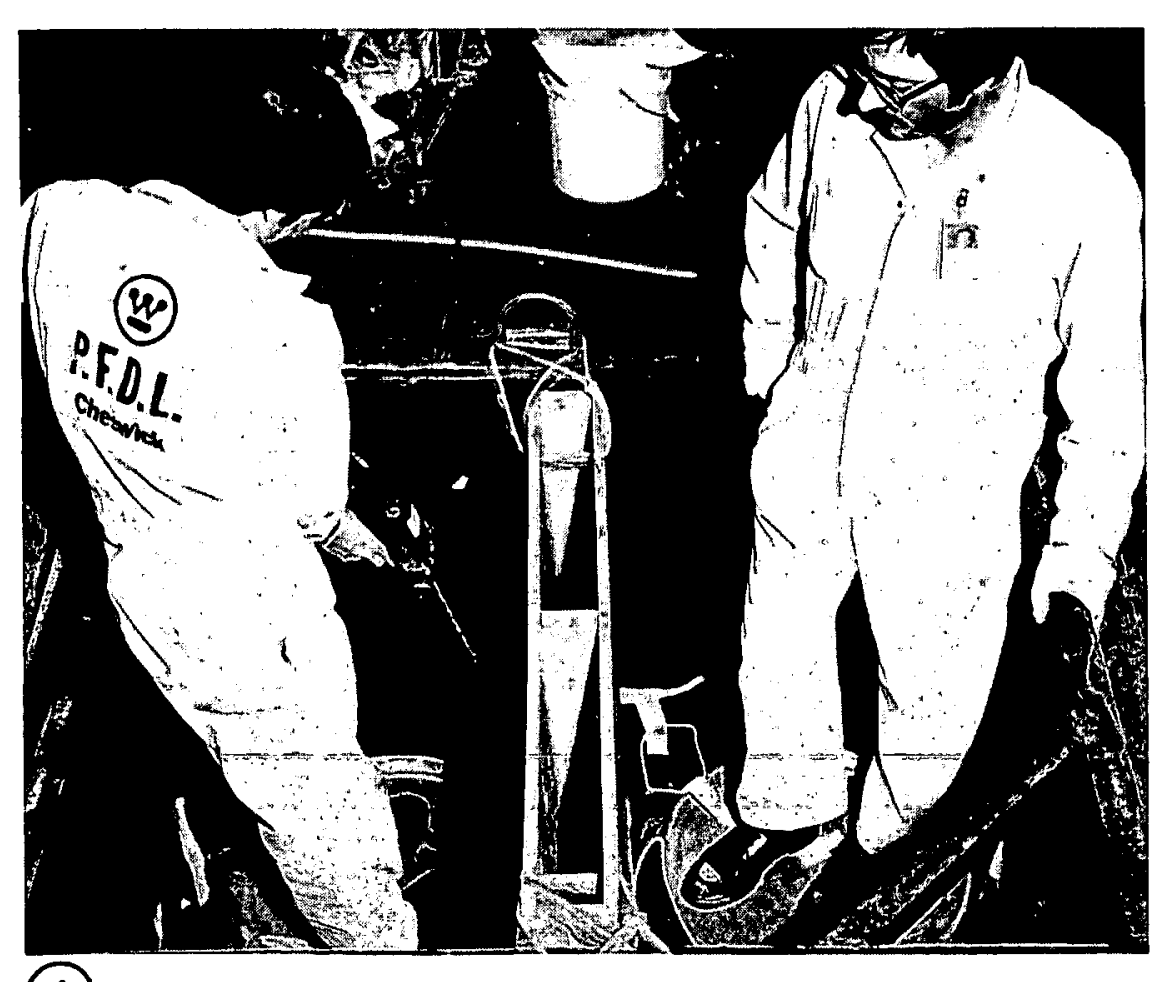

(4) Foaming to Provide Support and Restraint to Drums in M-III Bin
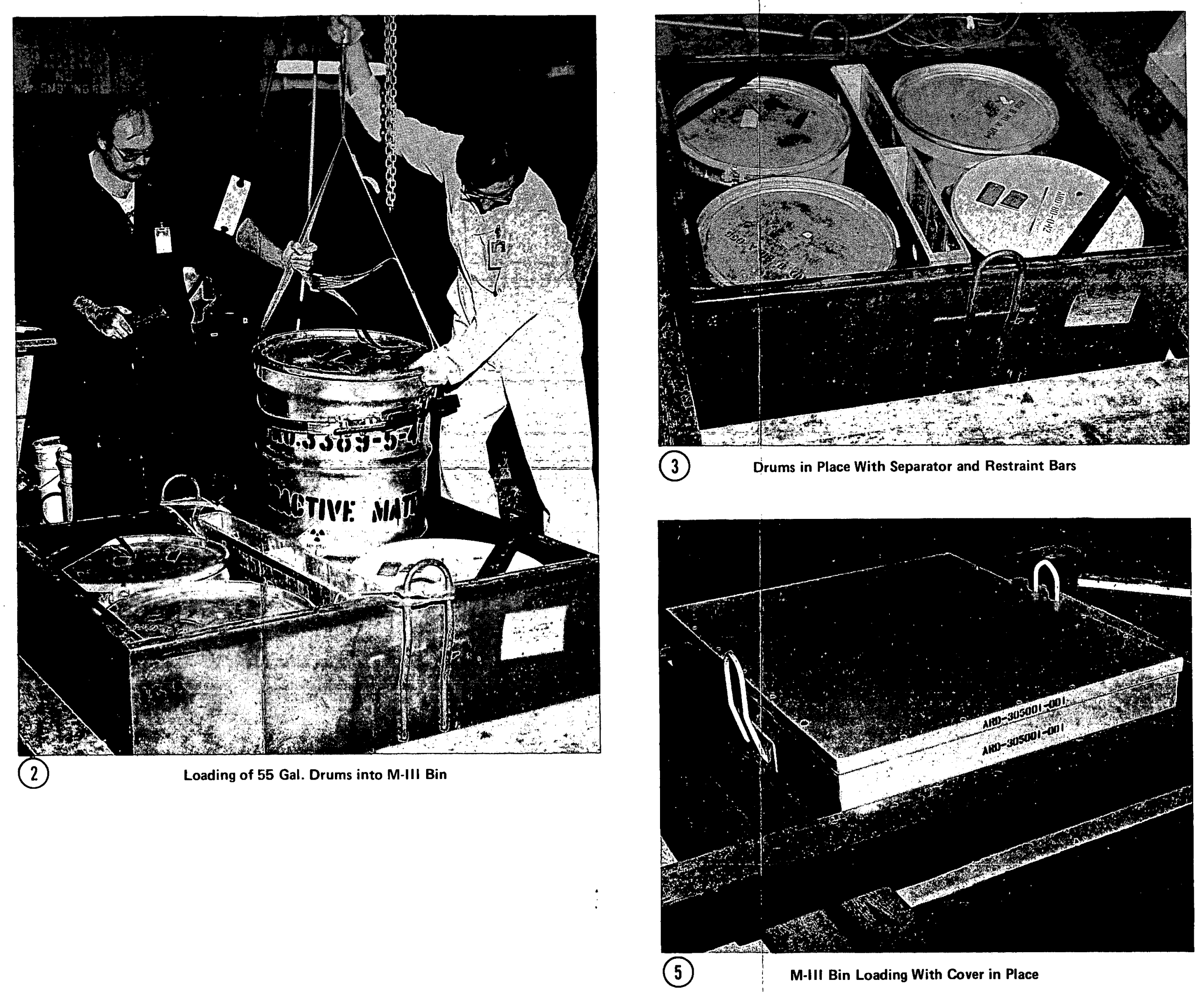

Figure 2-6. Loading of M-III Bins With Radioactive Waste at ARD Fuel Laboratories at Cheswick 
The first shipment of six loaded M-III bins was scheduled for September 16, 1980 , but was delayed because of problems with the Poly Panther overpacks received from the U.S. Ecology Company (formerly Nuclear Engineering Co.). Gaskets were missing from the overpack lids and the inner steel liner was torn on one overpack and punctured on another. U.S. Ecology Company supplied materials, procedures and supervision for field repairs on the lids and punctured inner liner, but concluded that field repair of the overpack with the torn inner liner was not feasible. The five usable overpacks were shipped on September 28, 1980. Figure 2-7 is a sequence of photographs that depicts loading the M-III bins into the Poly Panther overpack.

Concurrent with this effort, final packaging of glove boxes was accomplished. Glove box 11 (Building 7) was a completely clean box since it had never been cominitted to fuel work. This box and the preproduction FRP were used to develop handling, loading, foaming and seam sealing methods and procedures. The front and top panels of the FRPs, as built by the vendor, were only temporarily nailed in place for shipment, so that they were easily removed for glove box loading. Figure $2-8$ is a series of photographs illustrating the inassive construction detail of the FRP, the glove box in place, and the application of polyurethane foam. The last photograph in the sequence shows the front panel glued, screwed, and clamped in place. Figure 2-9 depicts the FRP prior to sealing and seam finishing and the subsequent sealing and seaming operations. It also shows the FRP completed and ready for shipment. A combination of wooden pallets and inflatable air bags were used to position the FRP inside the Model 6400 (Super Tiger) overpack; these items, the FRP loading operations and the Super Tiger closure operations are shown in Figure 2-10. The initial shipment of two FRPS was made on February 7, 1981 and Rockwell Hanford Operations (RHO) personnel stated that the FRPs arrived in excellent condition and unloading them caused no problems. The 21 st and final shipment was made to RHO on June 15, 1981. During the course of the FRP shipments, three Super Tigers obtained from Department of Energy (DOE) Richland Operations office (ROO) (no charge), Babcock and Wilcox Company (leased) and U.S. Ecology Company (leased) were utilized. 


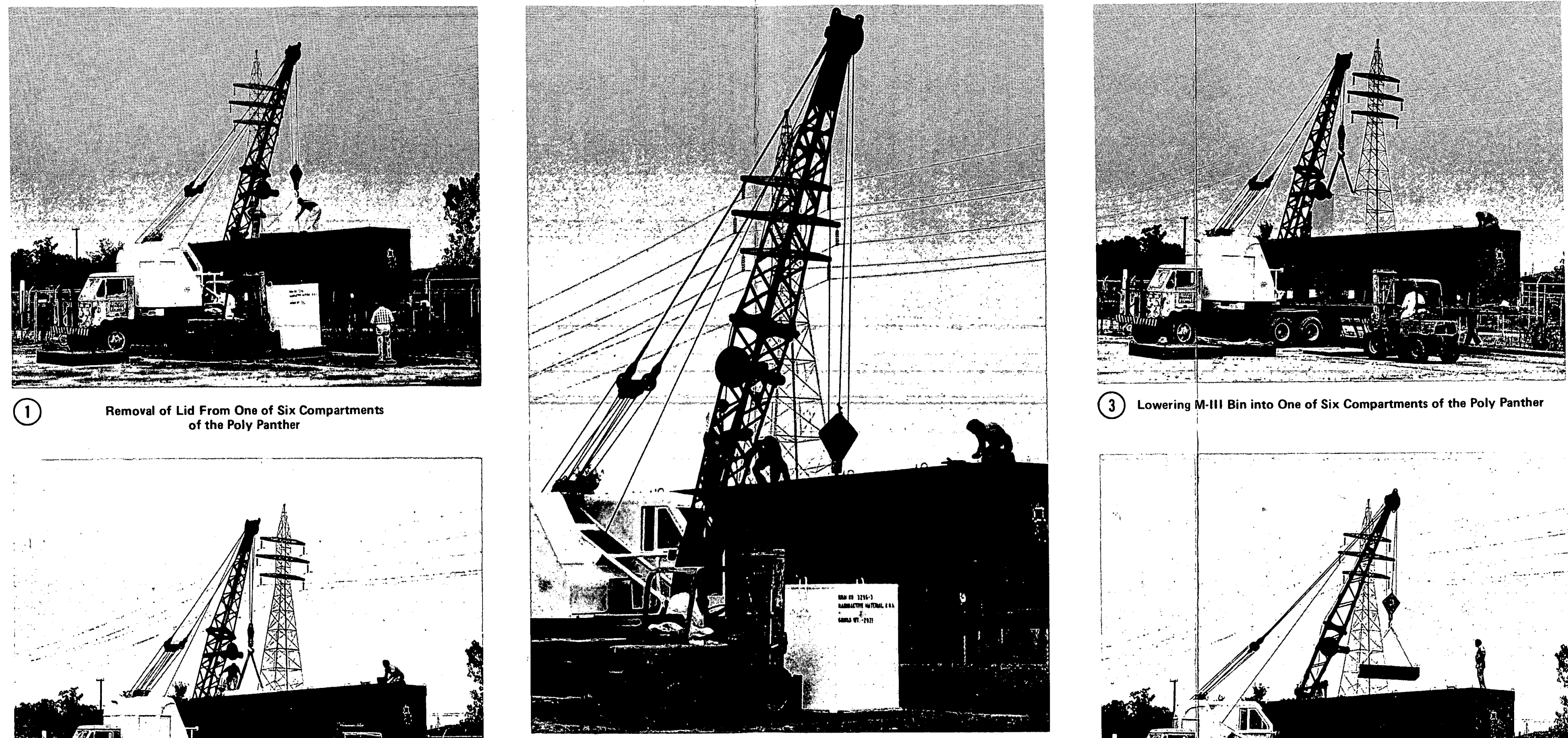

(1) Removal of Lid From One of Six Compartments

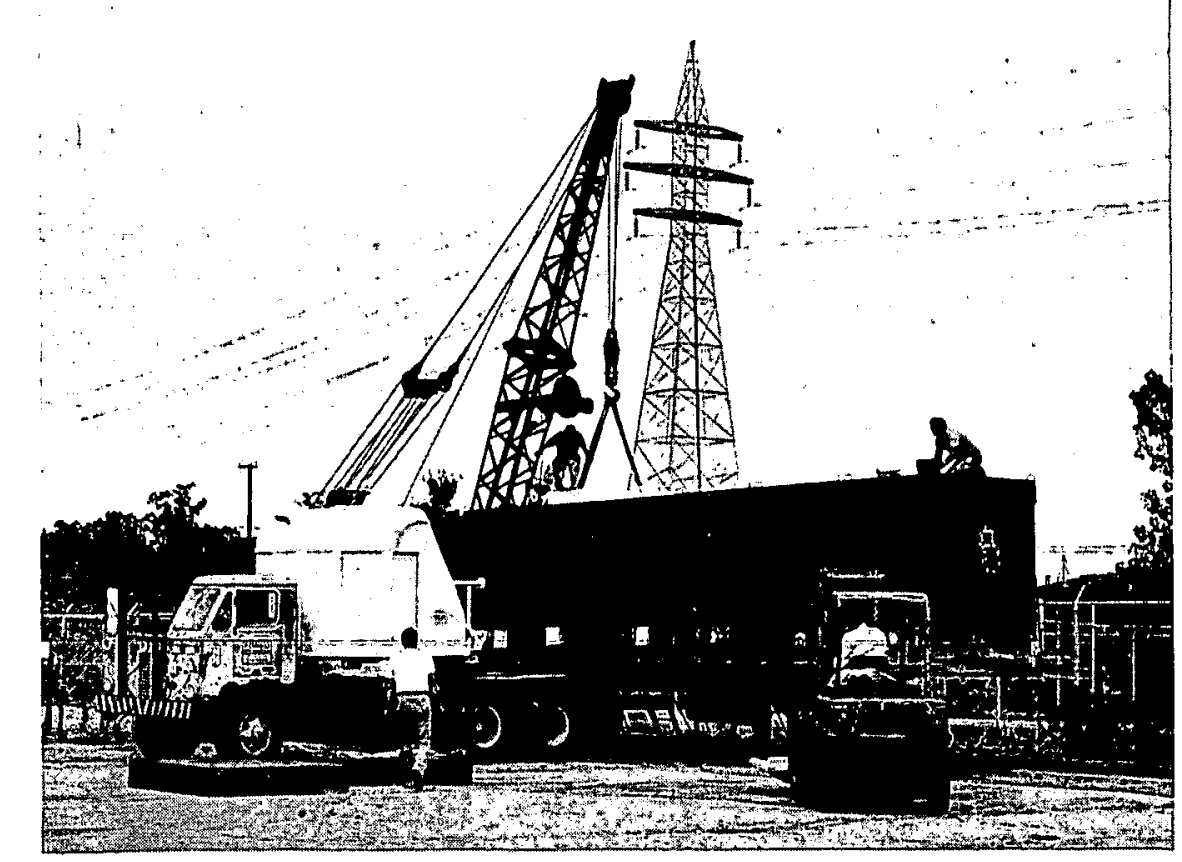

(2)

Preparing to Lift the M-III Bin

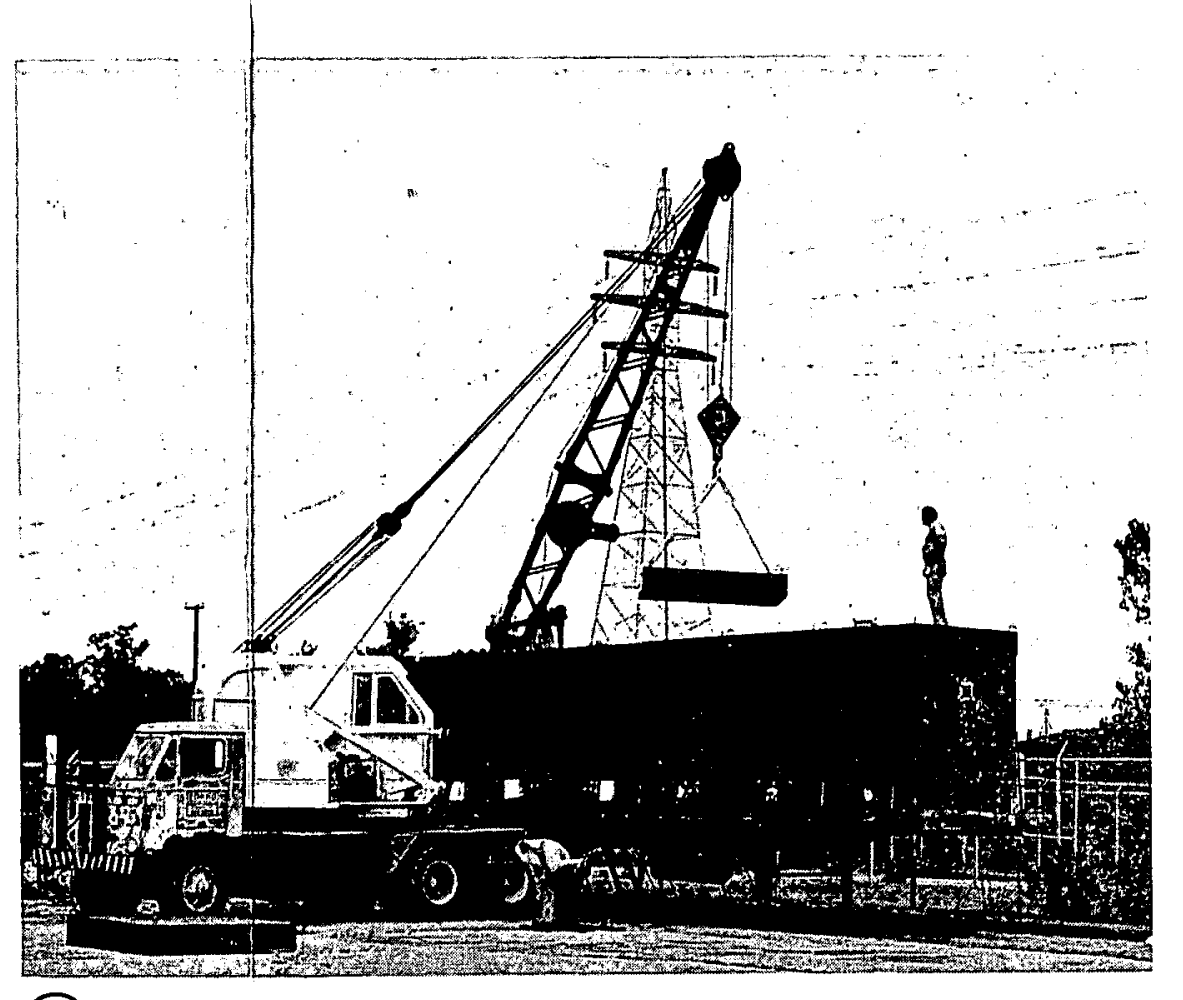

(4)

Completing the M-III Bin Loading

(5) Replacing the Lid to Close and Seal the Loaded Compartment

Figure 2-7. Loading the M-III Bins into the Poly Panther Overpack 


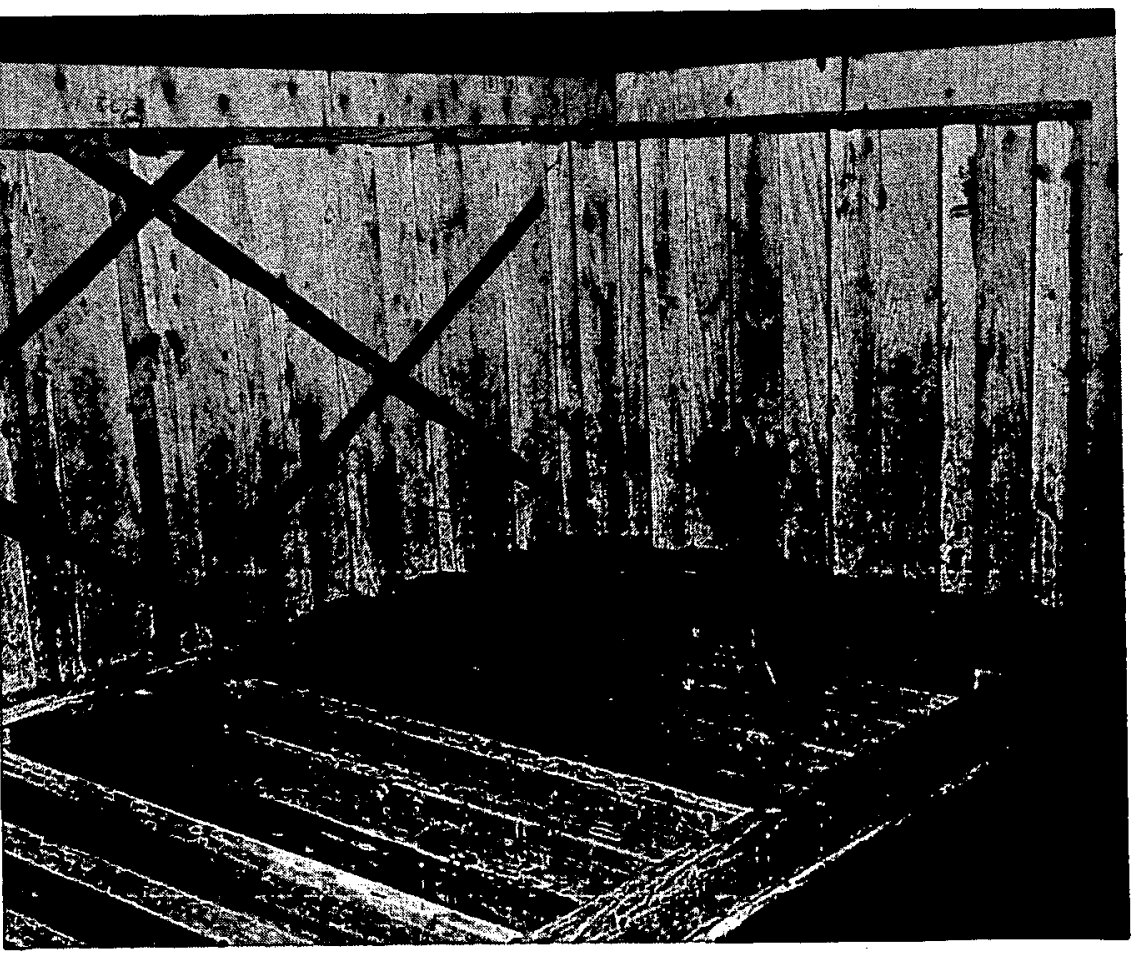

(1) The FRP With Front Side and Top Removed Prior to Loading

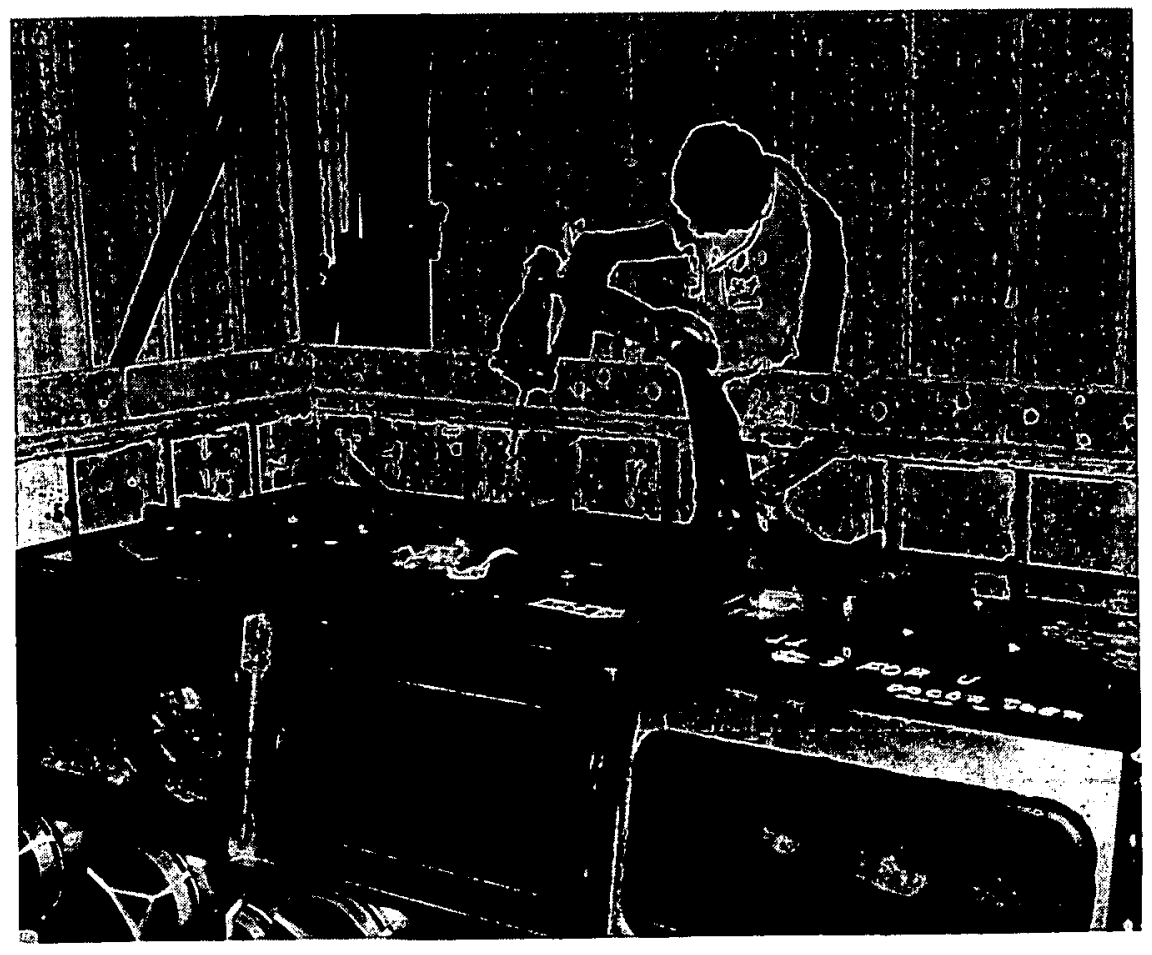

(4) Applying Foam to the Annular Region Between Side of

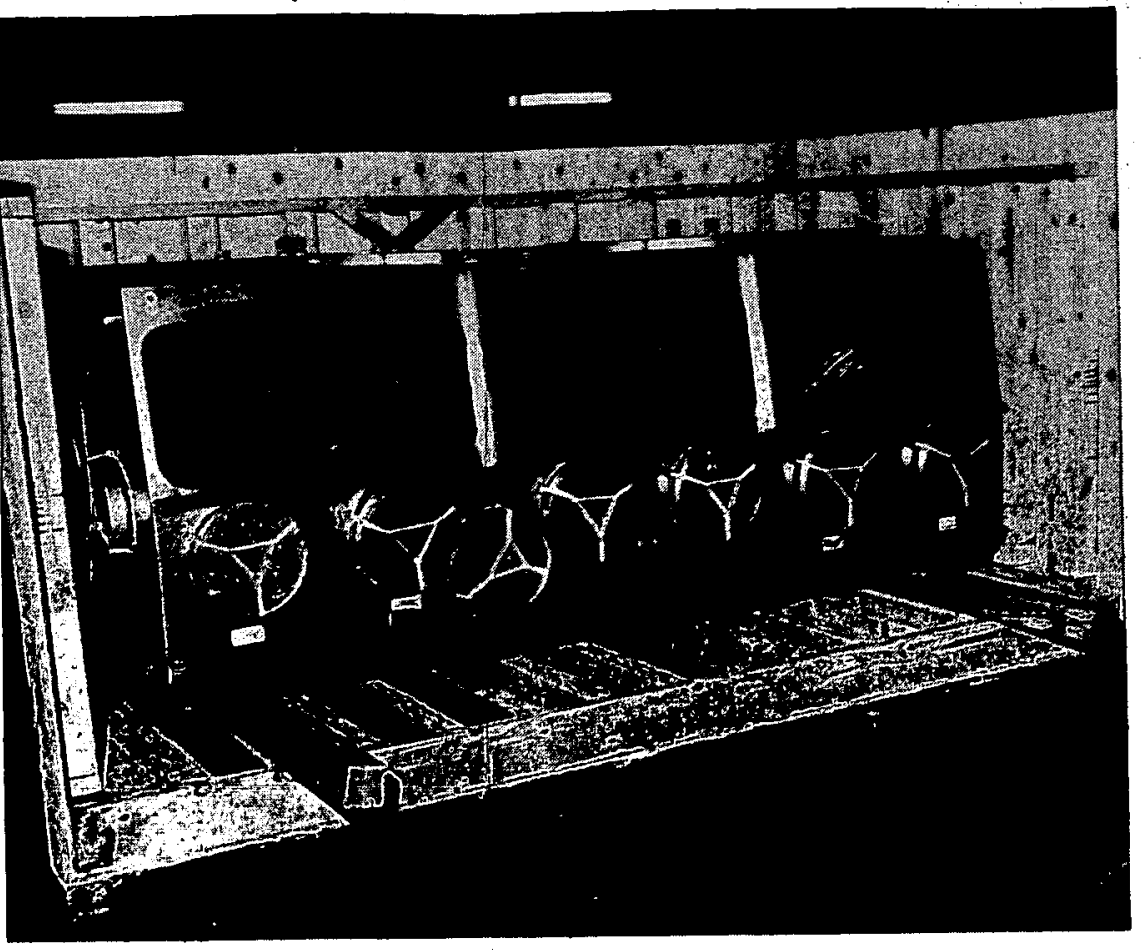

(2)

The Glove Box in Place

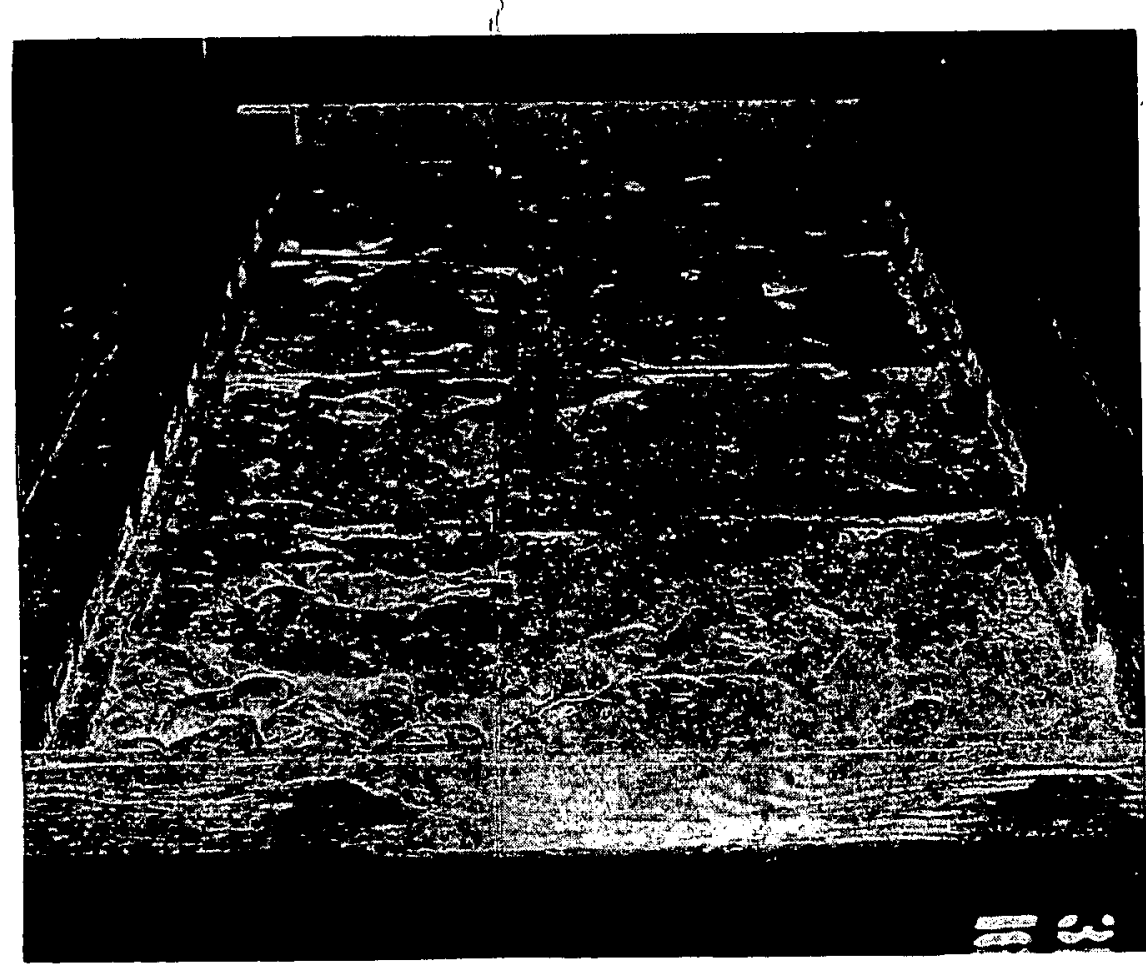

(5)

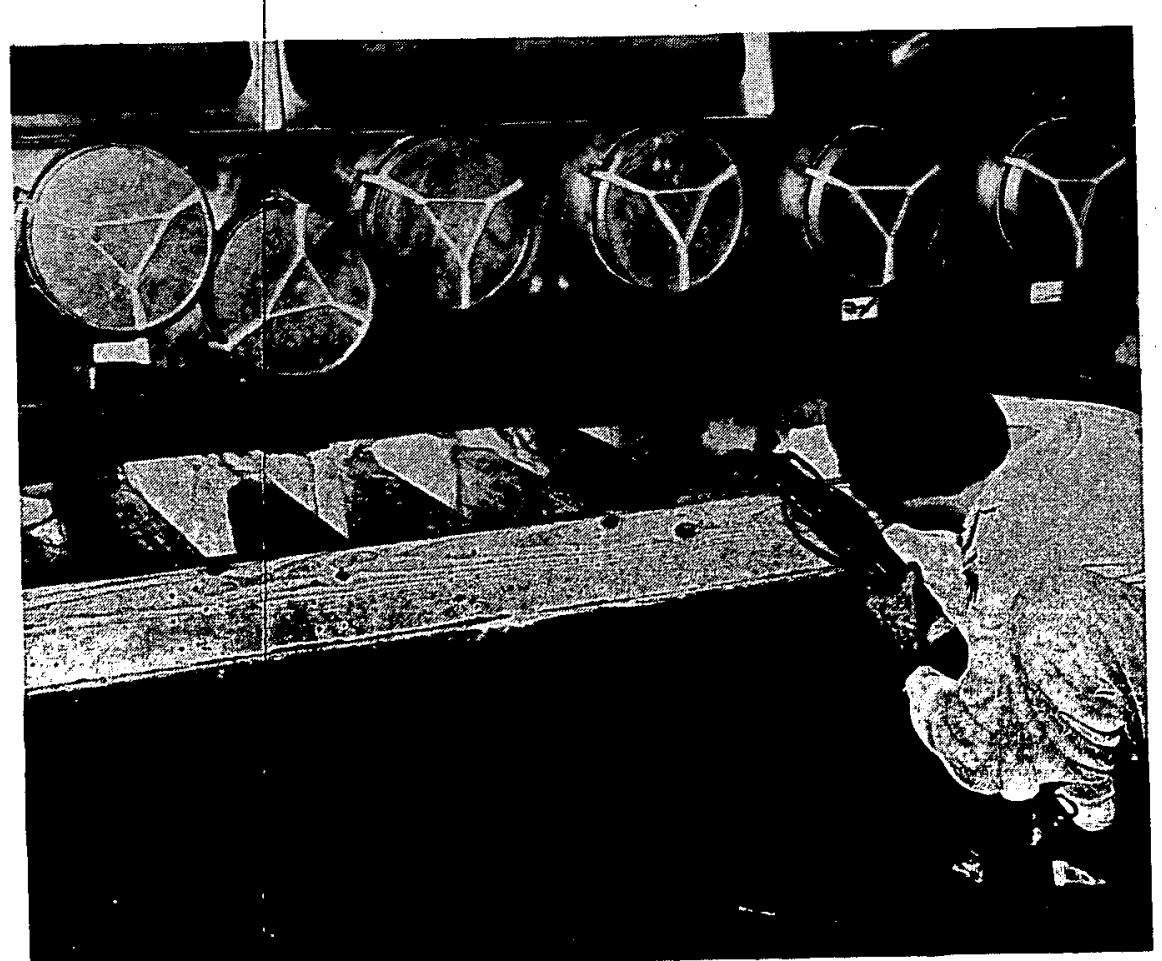

(3) Applying, Foam to Space Between Bottom of FRP and Glove Box

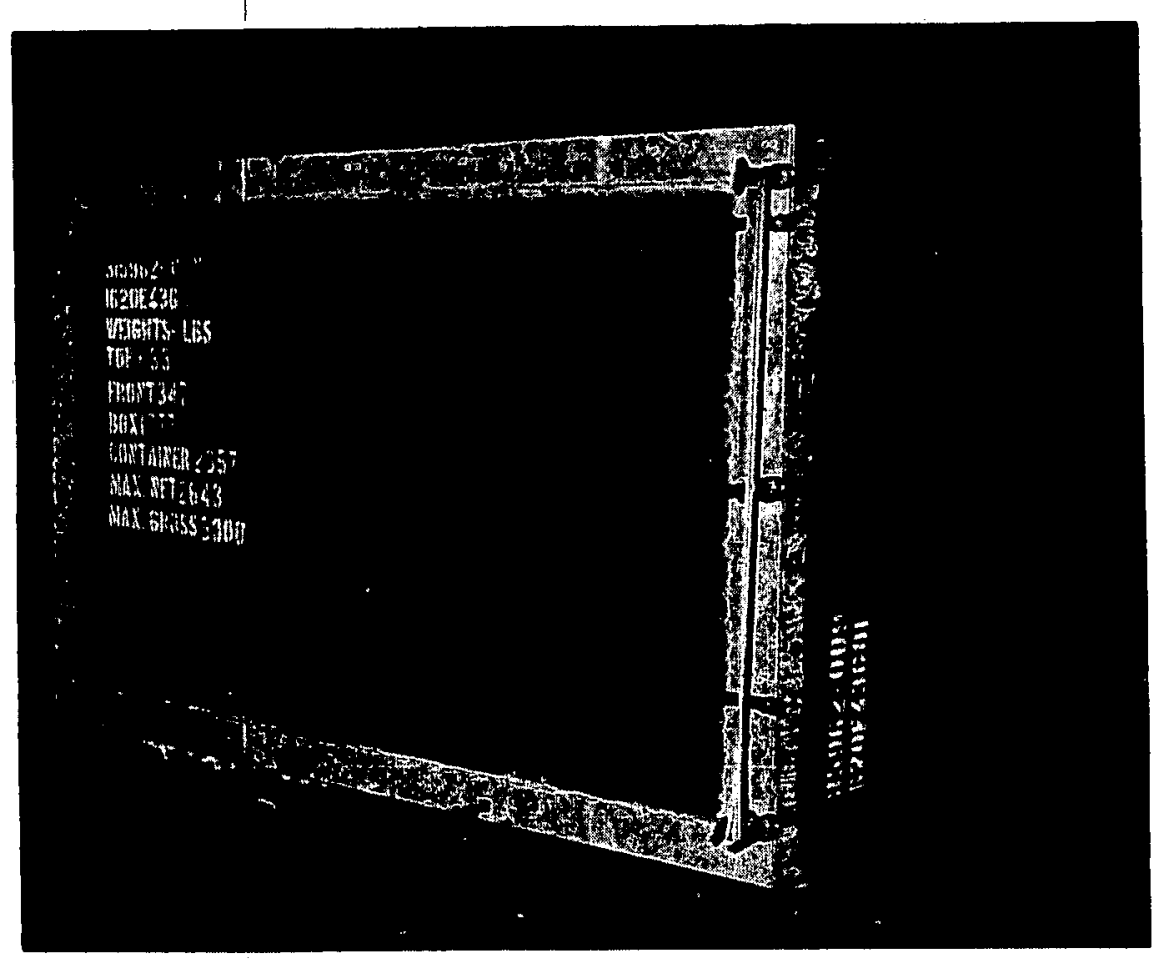

(6) Top and Sides Have Been Glued and Nailed in Place; Temporary Support Bars
Have Been Added to Hold Top and Sides in Place While Glue Hardens

Figure 2-8. Loading of Glove Box and Application of Foam 


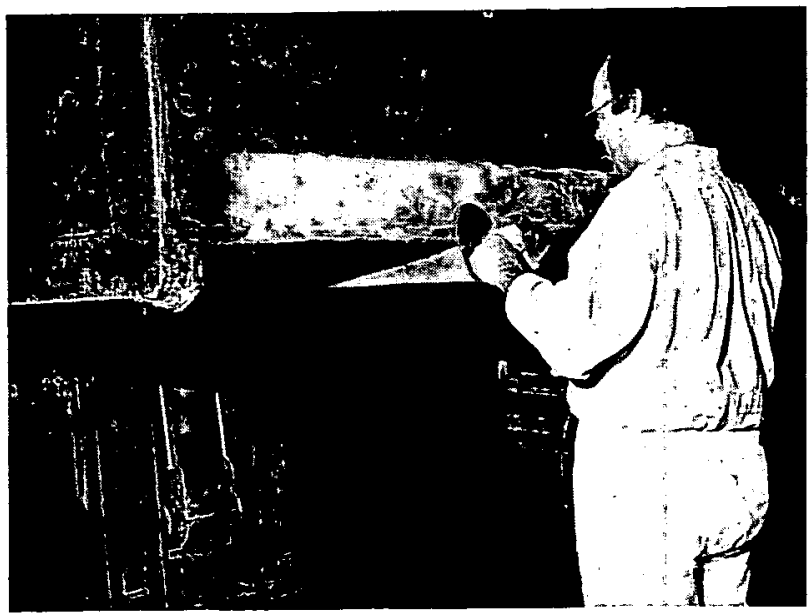

(1) Preparing Edges of FRP Prior to Adding
Fiberglass Reinforced Resin to Areas

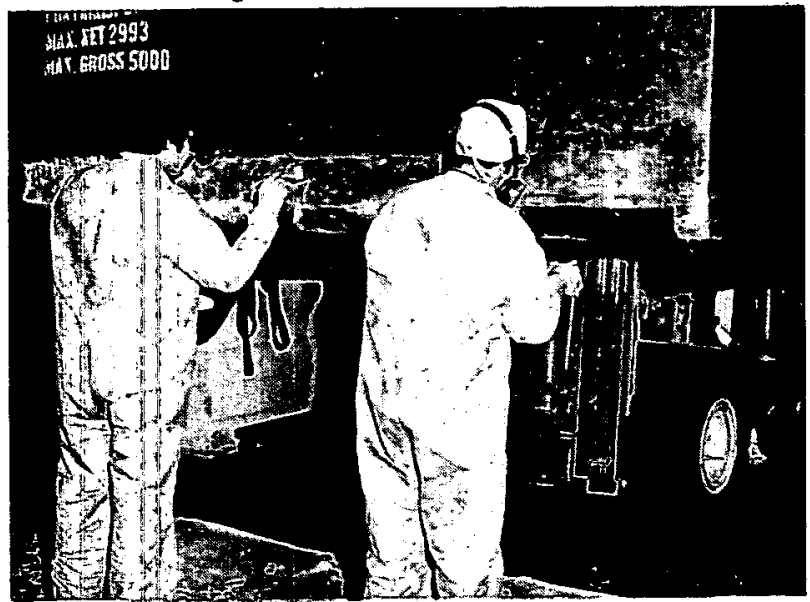

(2) Adding Fiberglass Reinforced Resin

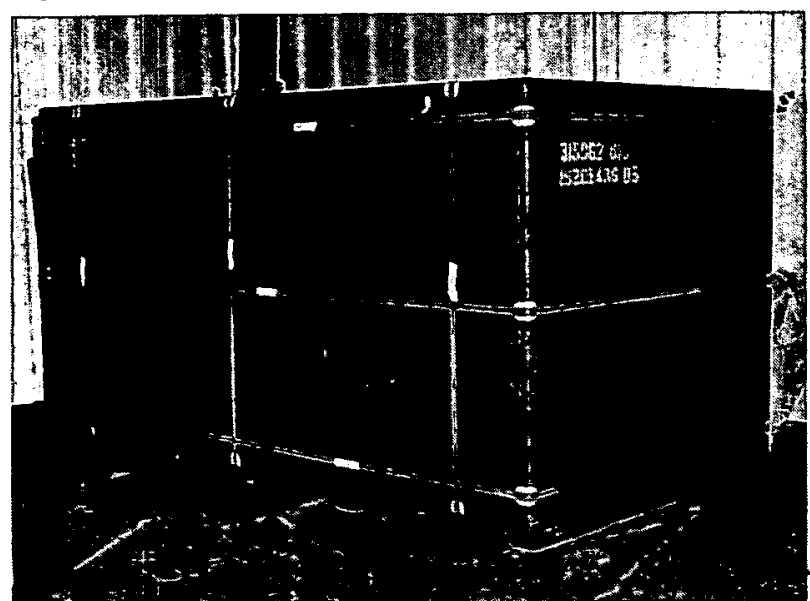

(3) The Finished Product Ready for Shipment and Burial

Figure 2-9. Sequence of Operations Prior to Completing FRP for Shipment 
。

• 


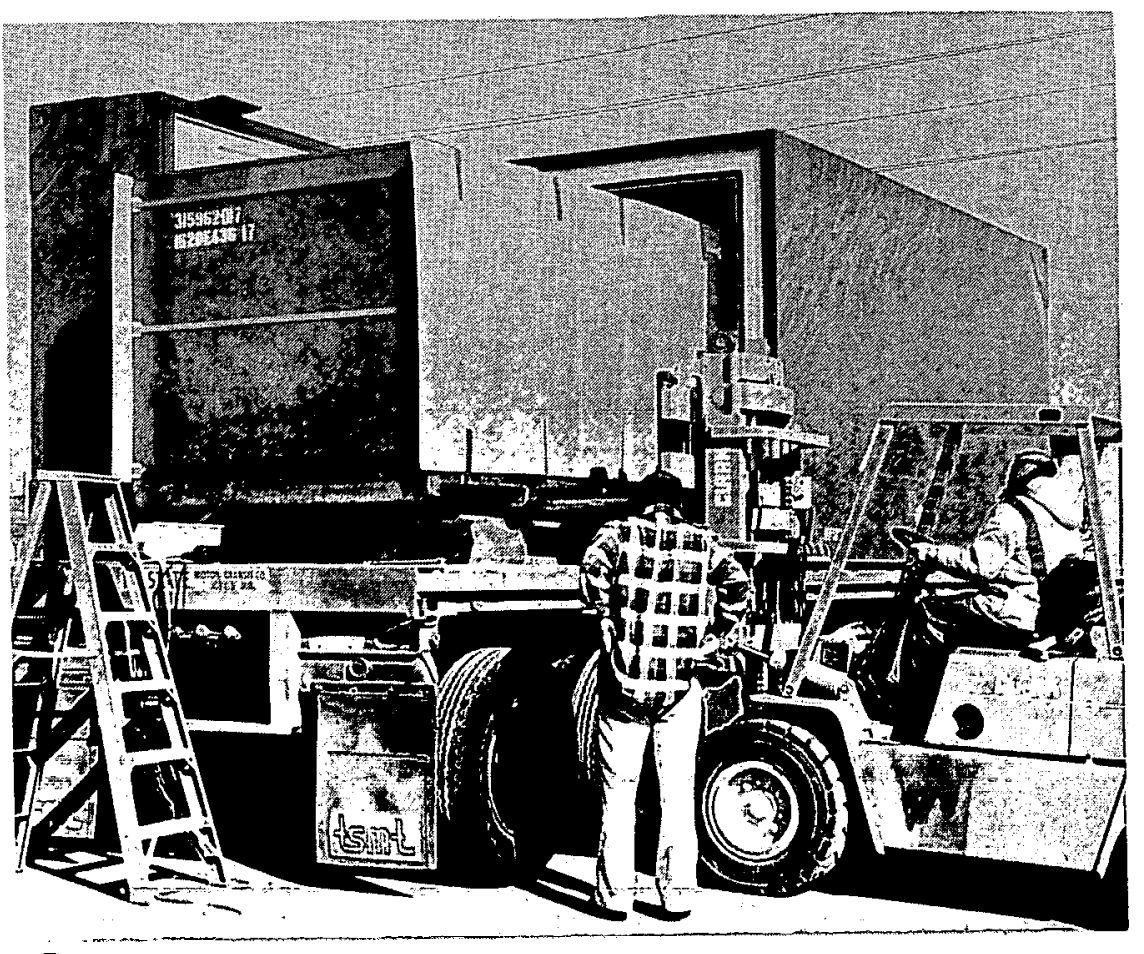

(1) Placing FRP onto Specially Constructed Decking on Back End of

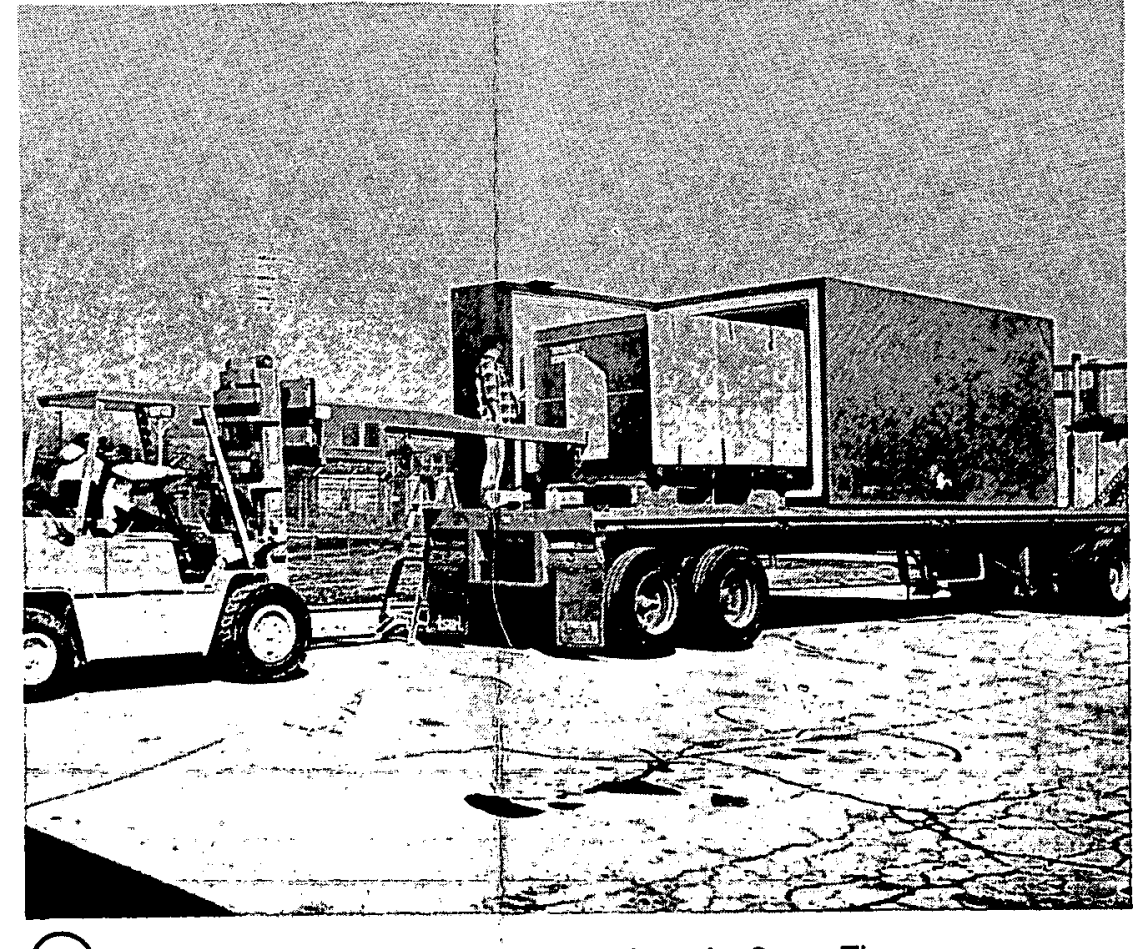

(2)

Sliding the FRP Forward into the Super Tiger

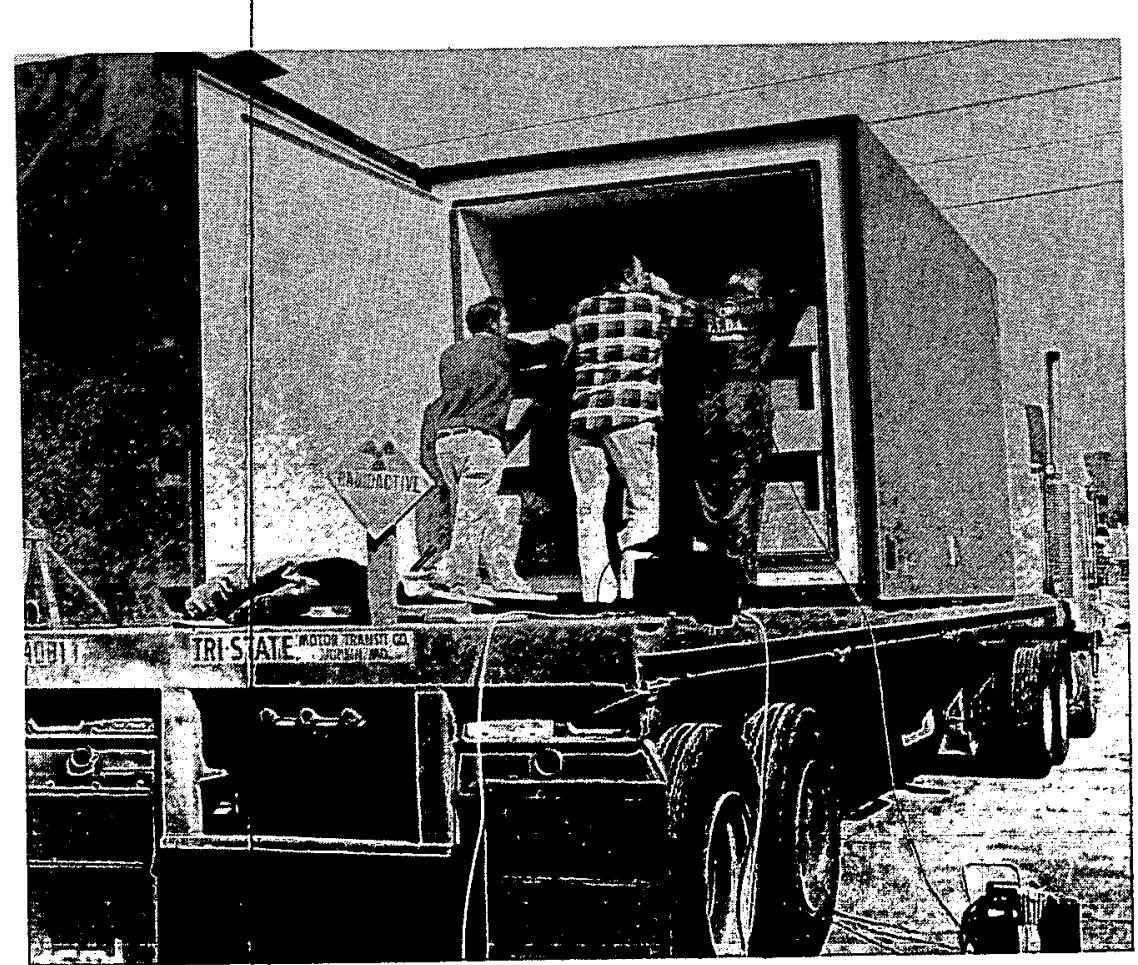
(3) App ying Back End Restraint, Including Inflatable Bags,

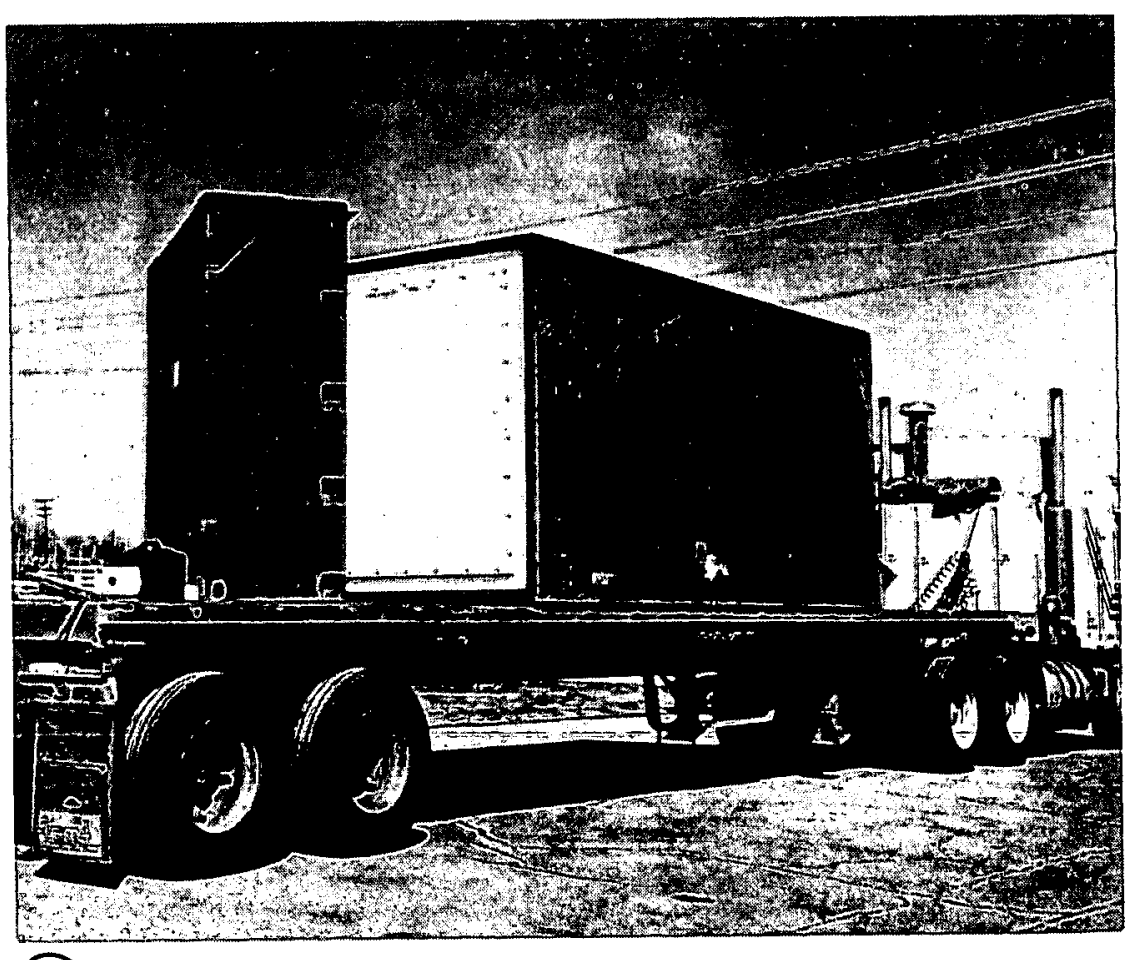

(4) All in Place Prior to Closing Back Gate

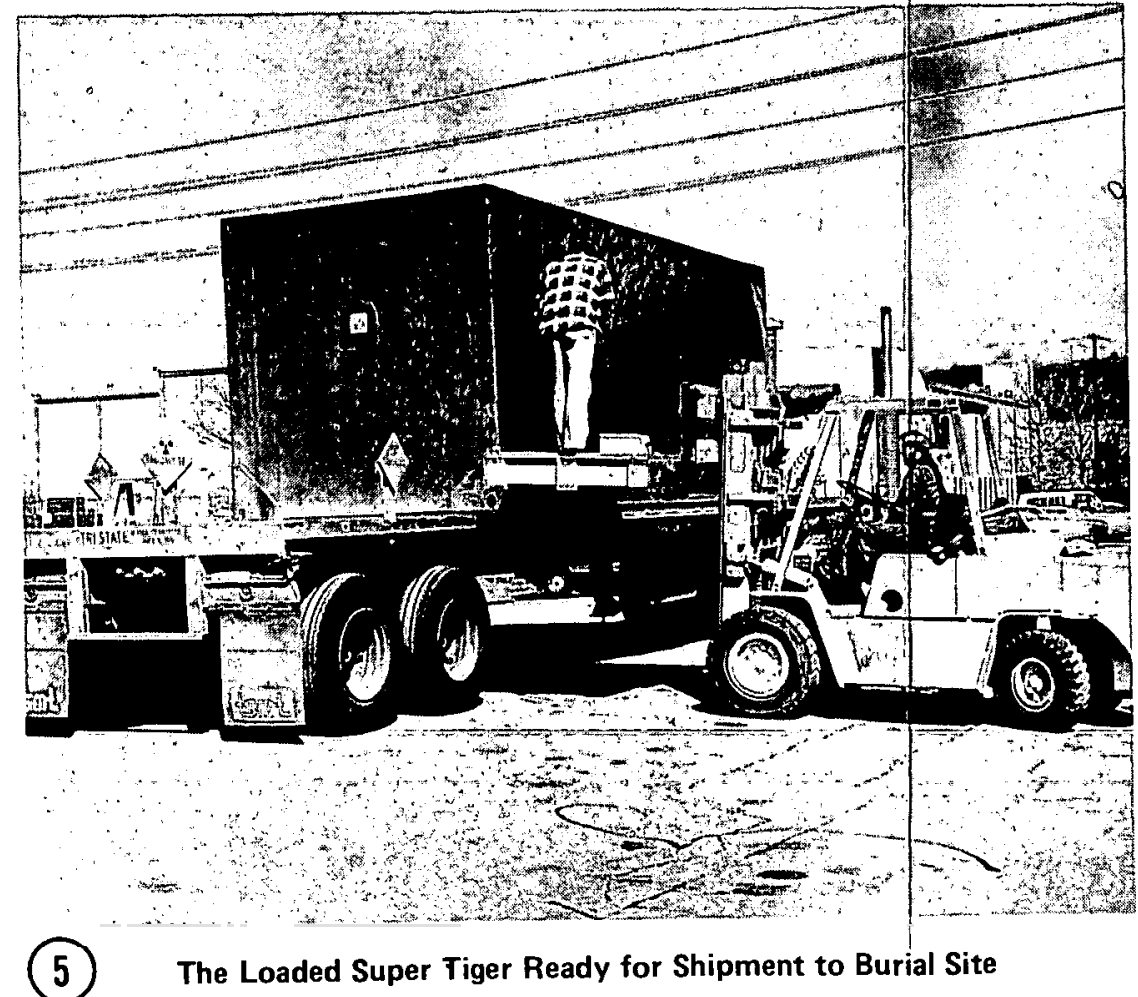

(5) The Loaded Super Tiger Ready for Shipment to Burial Site 


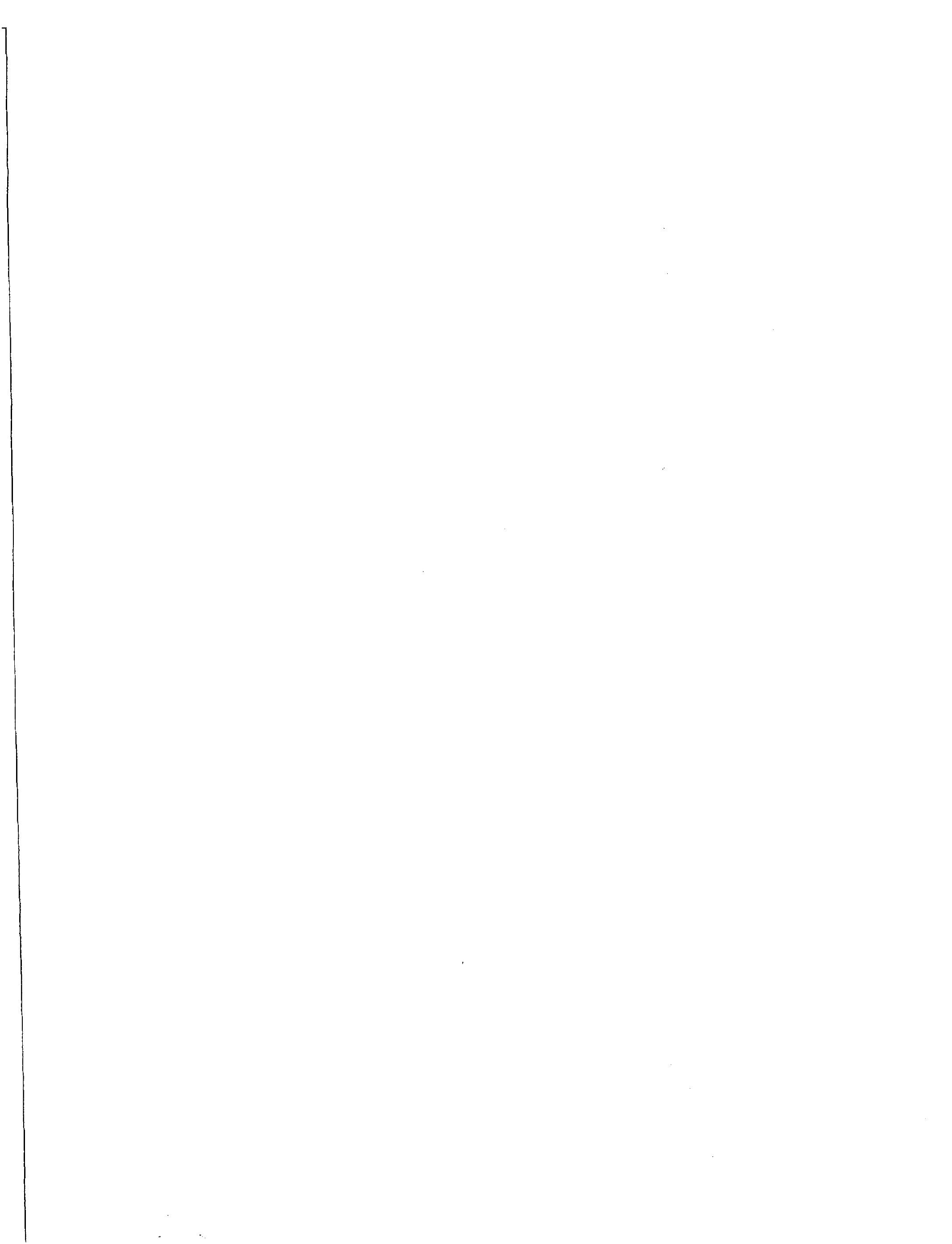


Upon completion of the packaging and shipping of the waste, efforts (Task 4) were initiated on final cleanup of the laboratories. A preliminary radiological survey of the surfaces and all holes in the surfaces of the floor, walls and ceiling was performed in the laboratory room (Building 8) prior to decontamination operations. Decontamination consisted of the chemical stripping of paint from the walls down to the bare plaster and from the floor down to the original epoxy base coat. This effort was required because these surfaces had been repainted during the course of laboratory operations (1970-79) resulting in the possibility of having covered over contamination that would be undetectable by alpha monitoring equipment. The ceiling had not been repainted during the laboratory operation period and therefore was not stripped. The stripping residues were dried, packaged and assayed. All surfaces including the ceiling were manually washed with detergent solution before the final, in-house, radiological survey was undertaken.

Upon completion of the removal of all services and duct work and the temporary installation of HEPA filters in the room ventilation and exhaust systems, a random sampling of the suspended ceiling tiles in the Building 7 laboratory was removed and surveyed for alpha and gamma contamination. No contamination was detected, which indicated a high probability that the plenum between the ceiling and the corrugated metal roof was radiologically clean. The suspended ceiling tiles and suspension hardware were removed, surveyed, and smeared and disposed of as clean waste. The walls, steel trusses and underside of the corrugated steel roof were surveyed, smeared and determined to be free of contamination. The paint on the floor was chemically stripped down to the original epoxy base coat since it had been painted during the course of normal laboratory operations (1967-1979). All roof, truss, wall and floor surfaces were washed with detergent solution to prepare them for the final in-house radiological survey. 


\subsection{SPECIAL PROBLEMS AND SOLUTIONS}

Two special problems that had a significant impact on project level of effort, schedule and costs were encountered during the D\&D program at Cheswick. Neither problem was identified during initial D\&D activities, but developed as the program progressed. These problems were:

A. A change in position by the operator of the burial site regarding the supply of shoring services for the burial of M-III bins and FRP-coated plywood boxes.

B. The removal from service of the Model 6400 (Super Tiger) Type B transportation overpack by the Nuclear Regulatory Commission following a field inspection.

This section provides background information, alternatives considered, and the final solution selected for each of these problems. This information should prove useful to other contractors conducting similar D\&D programs.

\subsection{PROBLEM NO. 1 - CHANGE IN POSITION ON SHORING OF CONTAINERS FOR BURIAL}

\section{BACKGROUND}

Early in the program (March, 1980), a visit was made to the Rockwell Hanford Operations (RHO), the operator of the designated DOE waste disposal site at Richland, Washington, to discuss ARO's preliminary plans for packaging and shipment of waste. The reference document used as a basis for these discussions was RHO-MA-222 entitled, "Hanford Radioactive Solid Waste Packaging, Storage and Disposal Requirements", DRAFT COPY dated January, 1980. (The final version of this document was issued in May, 1980). At this meeting, ARD proposed the use of the following three packages for the disposal of TRU waste:

A. The DOT 17C,55-gallon galvanized steel drum which meets DOT Spec 7A requirements. 
B. The Argonne National Lab (ANL) M-III Bin, a 12-gauge steel box with nominal dimensions of $4 \mathrm{ft}$ length $\times 5 \mathrm{ft}$ width $\times 6 \mathrm{ft}$ height and a column of $120 \mathrm{ft}^{3}$ constructed in accordance with ANL Drawing CS-E-2273. This package also meets DOT Spec 7A requirements.

C. A "strong, tight-fitting" plywood box coated with a FRP resin and sized to fit closely around a glove box. Although not designed at the time of the meeting, typical dimensions were estimated to be on the order of $9.5 \mathrm{ft}$ length $\times 4 \mathrm{ft}$ width $\times 5 \mathrm{ft}$ height. This package is hereafter referred to as an "FRP."

ARD recognized that neither the M-III bin nor the FRP would meet the 20 year retrievability requirements of RH0-MA-222, and more specifically, could not withstand the loads imposed by the burial over burden and the 27-ton bulldozer used for backfilling the trenches. RHO indicated that this was not a problem since external shoring in the form of timber and corrugated steel could be provided to support the burial/bulldozer loads. Cost of this external shoring constructed at the site was estimated at approximately $\$ 3000$ per container, to be borne by ARD. The meeting concluded with a verbal agreement that ARD's proposed usage of the three packages described above would be acceptable to $R H O$, and that $A R D$ would submit a formal request for package approval per RHO-MA-222.

Formal requests for package approval per RHO-MA-222 were submitted to RHO via DOE/CH for the DOT $17 \mathrm{C}$ galvanized steel drums and M-III bins on June 18, 1980 and an ARD-designed FRP box on July 25, 1980. Details concerning the FRP can be found on ARD Drawing 1519E34, Sub. 1. Briefly, the box was a glued and nailed construction consisting of $3 / 4$ inch plywood externally coated with fiberglass reinforced polyester and supported internally by a rather simple system of $2 \times 4$ and $2 \times 6$ trusses and cross-braces. A typical box was calculated to weigh approximately 900 pounds empty. The requests for both the $M-I I I$ bins and the FRP requested RHO to provide shoring to support burial loads.

Approvals to these requests were delayed for some time despite many discussions via telephone between engineering and project personnel of RHO and Westinghouse ARD. Finally, on September 10, 1980 westinghouse ARD was 
officially notified by Telefax that neither the M-III bin or the FRP packaging systems could be approved for burial; that RHO could not provide the shoring on the basis of cost and lack of equipment and rigging personnel for installing the shoring; and that data were not available that showed the M-III bin and FRP were capable of withstanding burial loads without shoring.

ALTERNATIVES CONSIDERED AND FINAL SOLUTION

A. M-III Bin

(1) Alternative No. 1

Alternative No. 1 consisted of performing an analysis of the $M-I I I$ bin to determine if it could withstand burial loads as defined by RHO-MA-222. The results of this analysis, as expected, were negative in that they predicted a catastrophic collapse of the package.

(2) Alternative No. 2

Alternative No. 2 was to conduct a controlled, instrumented, test wherein an actual M-III bin containing uncontaminated mock-up waste would be buried at the RHO burial grounds to determine if it could withstand actual burial loads.

In light of the results of the analys is performed under Alternative No. 1, this approach did not appear to be too promising, but RHO indicated that another contractor was willing to fund such a test. Subsequently, programmatic problems developed and the test was never performed.

(3) Alternative No. 3

The objective of this alternative was to determine if the M-III bins could be "shored up" internally. One approach considered was to stiffen the M-III bin walls by welding in place angle 
iron or channel iron stiffeners. An analysis indicated that each panel of the M-III bins would have to be divided into 16 sub-panels using 2 in $\times 3$ in angle iron. While this approach showed promise, it presented problems associated with the Certificate of Compliance for the Model 6272 (Poly Panther) Type $B$ transportation overpack used in conjunction with the M-III bins. The certificate requires the use of an M-III bin per ANL drawing CS-R-2273 inside the Poly Panther. If the M-III bins were modified, an application for revision of the certificate of Compliance would have to be submitted to the NRC for approval, a time-consuming process. Furthermore, the addition of stiffeners would have represented a significant decrease in payload weight and volume. For these reasons, this approach was abandoned.

A second approach considered was to package the waste in four secondary plywood packages, which would behave as column supports within the M-III bin. This alternative was developed to the point of producing engineering drawings and performing stress analysis. It was abandoned because:

(a) The secondary plywood packages and required shimming materials were quite heavy and reduced the package payload weight significantly.

(b) Fitup at loading became crucial. In order to keep stresses in the M-III bin wall within acceptable limits, practically all the clearance between the secondary plywood package and the M-III bin had to be eliminated. This proved to be impractical.

\section{(4) Alternative No. 4 - Final Solution}

Concurrent with the efforts being expended by ARD on the alternatives mentioned above, RHO was developing an alternative shoring concept that consisted of overpacking the M-III bins with a qualified, approved container prior to burial. A 
suitable container, detailed in RHO Drawing H-2-91888, was being developed by RHO for United Nuclear Industries (UNI). Briefly, this container was a $7 \mathrm{ft}$ length $\times 6 \mathrm{ft}$ width $\times 6 \mathrm{ft}$ height corrugated steel box (CSB) fabricated from $3 / 16$ inch thick steel plate. Additional strength was provided by corrugations pressed into the sidewalls, and structural stiffeners in the top and bottom.

The CSB passed a "vacuum test" that was judged to be an acceptable simulation of an actual burial, and RHO approved the package for burial. Subsequently, RHO and ARD agreed to use the CSB as a burial overpack for the M-III bins at an estimated cost of approximately $\$ 2000$ per bin. A total of $35 \mathrm{M}$-III bins were shipped to RHO; however, the actual cost of procuring the 35 CSBs escalated to greater than $\$ 5000$ each when procurement action was eventualiy accomplished by RHO in late 1981. Table 2-1 summarizes the M-III Bin Shipments.

TABLE 2-1

SUMMARY OF M-III BIN SHIPMENTS IN POLY PANTHER TYPE B OVERPACK

\begin{tabular}{|c|c|c|c|c|c|c|c|c|}
\hline \multirow{2}{*}{$\begin{array}{l}\text { SHIPMENT } \\
\text { NO. }\end{array}$} & \multirow{2}{*}{$\begin{array}{c}\text { DATE } \\
\text { SHIPPED }\end{array}$} & \multicolumn{3}{|c|}{ QUANTITY OF BINS } & \multirow{2}{*}{$\begin{array}{l}\text { PACKAGE } \\
\operatorname{VOLUME}(1) \\
\left(\mathrm{FT}^{3}\right)\end{array}$} & \multicolumn{2}{|c|}{ QUANTITY $(\mathrm{g})$} & \multirow{2}{*}{$\begin{array}{c}\text { TOTAL } \\
\text { ACTIVITY } \\
\text { (CURIES) }\end{array}$} \\
\hline & & COFBUSTIBLE & NONCOMBUSTIBLE & $\begin{array}{l}\text { ABSORBED } \\
\text { ORGANIC }\end{array}$ & & $\mathrm{Pu}$ & U & \\
\hline 1 & $9 / 29 / 80$ & 0 & 5 & 0 & 625 & 5 & ${ }_{\star}(5)$ & 7.43 \\
\hline 3 & $12 / 11 / 80$ & 1 & 5 & 0 & 750 & 67 & 122 & 88.27 \\
\hline 16 & $3 / 18 / 81$ & 0 & 5 & 1 & 750 & 98 & 97 & 117.09 \\
\hline 28 & $6 / 10 / 81$ & 3 & 3 & 0 & 750 & 65 & 63 & 81.53 \\
\hline $30^{(2)}$ & $6 / 25 / 81$ & 0 & 3 & 0 & 375 & 16 & 17 & 18.66 \\
\hline${ }_{31}(2)$ & $9 / 22 / 81$ & 0 & 3 & 0 & 375 & 66 & 18 & 56.13 \\
\hline $32^{(3)}$ & $10 / 6 / 81$ & 0 & 1 & 0 & 125 & * $(5$ & $\star(5)$ & 0.01 \\
\hline
\end{tabular}

NOTES

1. Based on nominal bin volume of $125 \mathrm{ft}^{3}$

2. Mixed shipment of 3 M-III bins for burial and 3 M-III bins containing drums. (See Table 2-4)

3. Mixed shipment of 1 NONTRU M-III bin for burial and 5 M-III bins containing drums. (See Table 2-4)

4. M-III bin containing NONTRU Waste excluded from total. Total TRU bins shipped $=35$

5. Less than 0.5 grams 


\section{B. FRP Plywood Box}

\section{(1) Alternative No. 1}

Upon receiving the first indication that RHO was modifying its position on shoring, ARD initiated redesign efforts for the FRP. This work culminated in the submittal of a request for package approval for the FRP described in Revision 2 of ARD Drawing 1619E94. Briefly, this version of the FRP was also a glued and nailed construction consisting of one-inch plywood sheathing reinforced by $2 \times 4$ studs spaced 12 inches apart in the sidewalls and $2 \times 6$ studs spaced 12 inches apart in the top and bottom. Five $4 \times 4 \mathrm{~s}$ also were attached to the bottom to provide a skid for handling the package. The entire external surface of the package was coated with FRP per Specification E-955048 (Attachment 6). The calculated weight of the same typical container mentioned previously had increased from w900 pounds to w 1600 pounds. The submittal was reviewed by RHO and comments were provided that required ARD to further redesign the FRP.

\section{(2) Alternative No. 2 - FINAL SOLUTION}

The redesigned FRP was completed by $A R D$ and the request for package approval was resubmitted to RHO. Details concerning this version of the FRP can be found on Drawing 1620E43, Sub 3 (Attachment 7). Major changes were the use of $4 \times 4 \mathrm{~s}$ on 12-inch centers in the sidewalls and $4 \times 6 s$ on 8 -inch centers in the top and bottom to reinforce the one-inch plywood sheathing. The calculated weight of the same typical container was 2400 pounds, a 2.7 fold increase compared to the original FRP design. Concurrently, the external volume of the FRP increased from $2175 \mathrm{ft}^{3}$ to $300 \mathrm{ft}^{3}$, a factor of 1.7. Table $2-2$ summarizes the dimensions, volume and weight for the FRP as it evolved throughout the program. 
TABLE 2-2

SUMMARY OF DIMENSIONS, VOLUME AND WEIGHT FOR FRP

\begin{tabular}{|c|c|c|c|c|c|}
\hline \multirow{2}{*}{$\begin{array}{l}\text { Dwg. No./Sub. No./ } \\
\text { Group No. }\end{array}$} & \multicolumn{3}{|c|}{ External Dimensions (in) } & \multirow{2}{*}{$\begin{array}{l}\text { Volume } \\
\left(\mathrm{ft}^{3}\right)\end{array}$} & \multirow{2}{*}{$\begin{array}{l}\text { Calculated Empty } \\
\text { Weight (Lbs.) }\end{array}$} \\
\hline & $L$ & $W$ & $H^{\star}$ & & \\
\hline 1619E34/Sub 1/Group 01 & 101.5 & 52.5 & 57 & 176 & 880 \\
\hline 1619E94/Sub $1 /$ Froup 01 & 112 & 58.5 & 69 & 261 & 1592 \\
\hline 1620E43/Sub 2/Group 01 & 115 & 70 & 65 & 302 & 2357 \\
\hline
\end{tabular}

RHO approved this version of the FRP for burial on January 29, 1981. The average fabrication cost per FRP increased from $\$ 2000$ for the original design to $\$ 3500$ for the final approved design. A total of 21 glove boxes were packaged and shipped for burial using this container.

\subsubsection{PROBLEM NO. 2 - REMOVAL OF SUPER TIGERS FROM SERVICE}

\section{BACKGROUND}

The nature of the TRU waste generated during the D\&D of the Cheswick facility was such that shipments contained Type B quantities (that is, >.001 curies) of plutonium. In accordance with Code of Federal Regulations 10CFR71 and 49CFR 173, the transportation of such shipments required the use of Type $B$ overpacks. Originally, it was planned to utilize the U.S. Ecology Company Poly Panther (NRC Certificate of Compliance No. 6272) to overpack the M-III bins and the U.S. Ecology Super Tiger (NRC Certificate of Compliance No. 6400) to overpack DOT $7 C$ drums and "strong, tight-fitting" FRP plywood boxes. 
Upon issuing Revision 8 to the NRC Certificate of Compliance No. 6400 for the Super Tiger on February 29, 1980, the NRC requested all owners/users to perform an inspection of their Super Tigers to determine if they were in compliance with drawings and submit results of the inspection by April 30 , 1980. Inspection results indicated that all six Super Tigers (three DOE-owned and three commercially-owned) were out-of-compliance to varying degrees and were removed from service.

Subsequently, in September 1980, ARD learned that the NRC wanted further verification that the Super Tigers met the following two regulation requirements:

A. $71.32(b)$ The containment vessel will suffer no loss of contents if subjected to an external pressure of 25 psig.

B. 71.32 (Appendix A, Item 3) Under normal conditions of transport, the package must withstand atmospheric pressure of 0.5 times standard atmospheric pressure.

In addition, the NRC also expressed concern about the low temperature ductility of the carbon steel used in the Super Tiger and its susceptibility to brittle fracture.

The net impact of the aforementioned items was that as of February 29, 1980, ARD did not have an overpack for transportation of TRU waste packaged in DOT $17 \mathrm{C}$ drums and "strong, tight-fitting" FRP plywood boxes. 
A. DOT 17C Drums

Alternative No. 1 - Final Solution

Since the solution for transporting DOT 17C drums was straightforward, other alternatives were not considered. The solution was to substitute the Poly Panther (Model 6272) Type B transportation overpack for the Super Tiger (Model 6400). This approval involved loading eight DOT $17 \mathrm{C}$ drums into $M-I I I$ bins which in turn were loaded into the Poly Panther. A total of six Poly Panthers were mounted on a single flat-bed trailer resulting in a shipment comprised of 48 drums. Upon receipt of the Poly Panthers at the burial grounds, RHO personnel unloaded the M-III bins and removed the drums from each. The empty M-III bins were placed into the Poly Panthers and returned to ARD for reuse.

A cost analysis was performed wherein the use of the two overpacks was compared and the results are summarized in Table 2-3. Using the Poly Panthers represented a savings of $\$ 6.41$ per cubic foot, $\$ 48.07$ per drum and $\$ 1,120$ per shipment. Furthermore, for a particular quantity of drums, fewer shipments were required using the Poly Panther.

Additional savings were realized from using the Poly Panther since the drums did not have to be lined with a two-inch annular thickness and three-inch end thickness of polyurethane foam as required for the Super Tiger. In addition to the savings in material and labor costs, the elimination of the foam increased the useful volume of the drum by $83 \%$ ( 30 gallons vs 55 gallons).

The use of the Poly Panther did have one disadvantage in that each was limited to 20 curies of total activity compared to a limit of 60 grams of plutonium per drum for the Super Tiger. This potential problem was circumvented by careful management of drum loading so as to keep the average drum activity to a value of 2.5 curies. 


\begin{tabular}{|c|c|c|c|c|}
\hline \multicolumn{5}{|c|}{ TABLE $2-3$} \\
\hline \multicolumn{5}{|c|}{ COST COMPARISON OF DRUM SHIPMENTS: SUPER TIGER VS POLY PANTHER } \\
\hline I & \multicolumn{2}{|c|}{ INFORMATION } & SUPER TIGER (1) & POLY PAITHERS (6) \\
\hline & \multirow{4}{*}{\multicolumn{2}{|c|}{$\begin{array}{l}\text { 1) Assume Round Trip Usane for } \\
\text { Drum Disposal } \\
\text { 2) Rockwell Handlinn Charges } \\
\text { are Unknown } \\
\text { 3) Basis for Costs Derivation: } \\
\text { a) Drums (Full Load) } \\
\text { b) Total Volume } \\
\text { c) Dverpack(s) Rental/Day } \\
\text { d) Days/Trip }\end{array}$}} & \multirow[b]{4}{*}{$\begin{array}{l}42 \\
315 \mathrm{Ft}^{3} \\
\$ 250 \\
11\end{array}$} & \multirow[b]{4}{*}{$\begin{array}{l}48 \\
360 \mathrm{Ft}^{3} \\
5110 \\
11\end{array}$} \\
\hline & & & & \\
\hline & & & & \\
\hline & & & & \\
\hline \multirow[t]{7}{*}{ I I } & \multicolumn{2}{|c|}{ COSTS } & & \\
\hline & \multirow{3}{*}{\multicolumn{2}{|c|}{$\begin{array}{l}\text { 1) Overpack(s) Rental/Trip } \\
\text { 2) Handling Charge } \\
\text { 3) Round Trid Transportation } \\
\text { (Teani) }\end{array}$}} & $\$ 2,750$ & $\$ 1,210$ \\
\hline & & & \multirow{2}{*}{$\begin{array}{r}300 \\
6,520.36\end{array}$} & 300 \\
\hline & & & & $6,520.36$ \\
\hline & & $\begin{array}{l}\text { Sum of Numbers } 1,2 \text {, and } 3 \text {, } \\
\text { Above }\end{array}$ & $\$ 9,750.36$ & $\$ 8,030.36$ \\
\hline & & Crane Rental - Cheswick & $N / A$ & $600.00^{\star}$ \\
\hline & & Sum of Numbers 4 and 5 & $\$ 9,750.36$ & $58,630.36$ \\
\hline III & \multicolumn{2}{|c|}{ DIFFERENCES } & & \\
\hline & & $S / \mathrm{Ft}^{3}$ & 30.38 & 23.97 \\
\hline & & $\therefore, S / \mathrm{Ft}^{3}$ & +6.41 & \\
\hline & 3) & S/Orum & 227.35 & 179.78 \\
\hline & 4) & $\therefore, S /$ Drum & +48.07 & \\
\hline & 5) & $\$ /$ Shipment & $9,750.36$ & $8,630.36$ \\
\hline & & $\therefore$, S/Shipment & $+1,130.00$ & \\
\hline
\end{tabular}

Subsequently, a revised request for package approval utilizing the Poly Panther as an overpack was submitted to RHO and approval was granted. A total of 232 drums containing a total of 517 curies of radioactivity were shipped in this manner. Table 2-4 summarizes the drum shipments in Poly Panthers. 


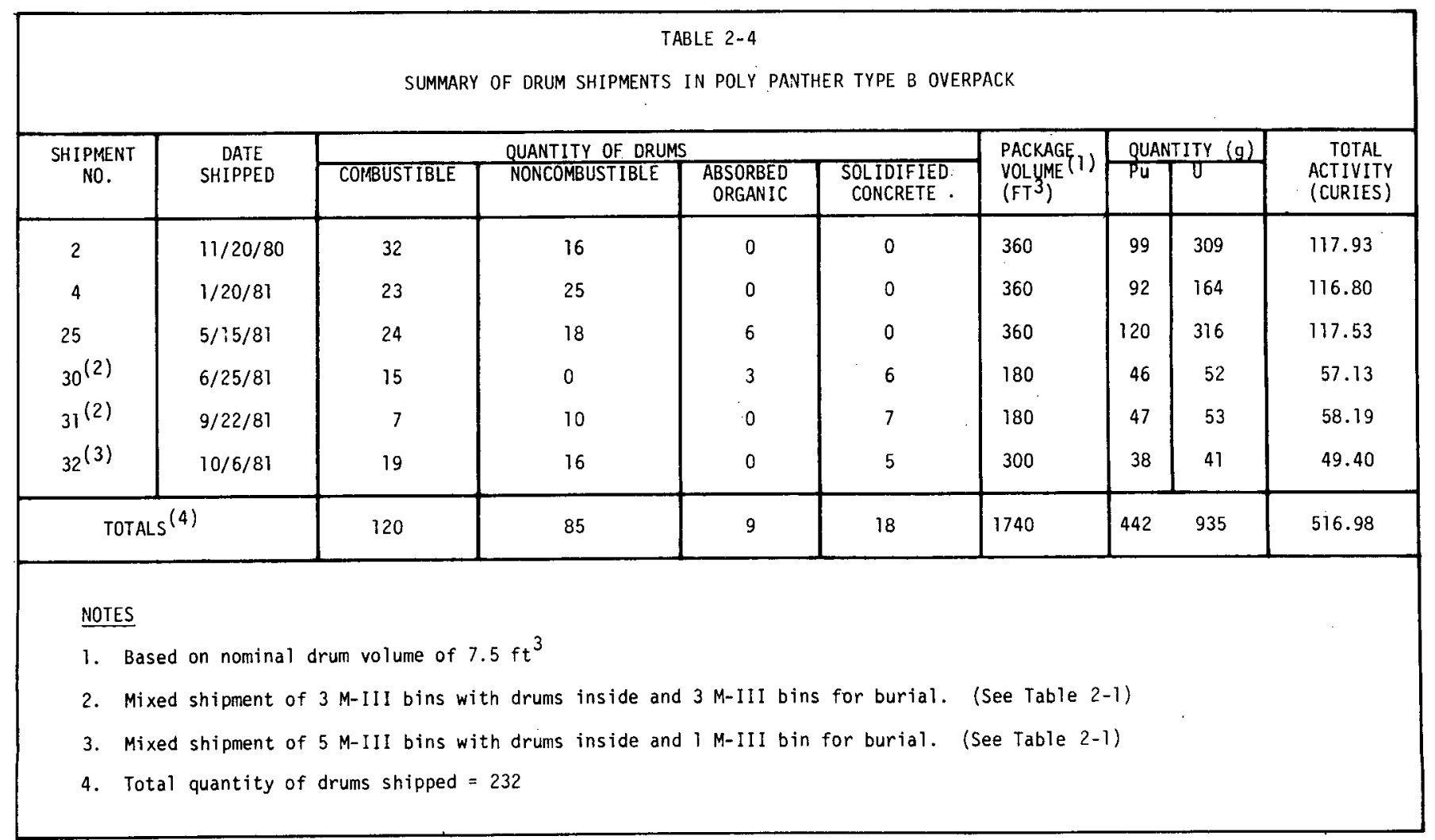

\section{B. Plywood Boxes}

(1) Alternative No. 1

One alternative considered was to repair and retrofit the Super Tigers to bring them into compliance with the NRC regulations. While the repairs required to bring the Super Tigers into compliance with the existing drawings were reasonable, the modifications required to demonstrate compliance with the 25 psig requirement became exorbitant. A preliminary analysis by U.S. Ecology Company indicated that a structure of $5 \times 5$ wide-flange steel beams would be required to stiffen the inner wall sufficiently. This alternative was eliminated for the following reasons:

(a) The Super Tiger owners were not interested in expending funds to repair and retrofit their existing design. 
(b) The preliminary analysis by U.S. Ecology Company indicated that dimensions of the internal cavity would be reduced by ulo inches on a side. This reduction was not compatible with the dimensions of the FRP.

(c) The problem with brittle fracture of carbon steel at low temperatures was unaddressed.

\section{(2) Alternative No. 2}

A second alternative was to design and build a completely new Super Tiger that would be in full compliance with NRC regulations. U.S. Ecology Company had initiated a redesign effort and estimated it would take six months to obtain NRC approval and six months for construction at an estimated cost of $\sim \$ 130,000$ per unit. If the NRC required the material of construction to be stainless steel, U.S. Ecology Company stated. that the cost would increase by a factor of three. This alternative was eliminated because of:

(a) Uncertainty of NRC requirements

(b) Estimated costs and schedule for construction of a new Super Tiger were not compatible with D\&D program funds and schedule.

\section{(3) Alternative No. 3}

A third alternative considered was to size/volume reduce the glove boxes so that they would fit into M-III bins and subsequently be shipped in the Poly Panther. This alternative was eliminated because:

(a) A reduction facility did not exist at the Laboratories and preliminary estimates of construction costs and schedule were not compatible with $D \& D$ program requirements. 
(b) Operating a reduction facility would subject personnel to hazardous handling operations and enhance the potential for puncture-type wounds.

(c) Development work at BMI Columbus indicated nine drums (55 gallon) of secondary TRU waste were generated per glove box processed through reduction operations.

(d) Size reduction of glove boxes was judged to be a labor intensive operation that would result in an overall schedular delay.

(4) Alternative No. 4 - Final Solution

The fourth alternative considered and eventualiy selected as the final solution was to request an exemption from the requirements of 10CFR Part 71.42(b)(3) for the Super Tiger from the NRC. The NRC indicated they would consider such a request if the following items were addressed:

(a) Provide a narrative and marked up drawing of the specific Super Tiger proposed for use which describes its current condition.

(b) Provide a description of the treatment (that is, decontamination and fixation) and secondary packaging to be used for transporting the glove boxes in the Super Tiger.

(c) Provide a safety evaluation that demonstrates that the treatment and packaging will provide protection against a release of radioactive material during normal conditions of transport (10CFR71, Appendix A) and hypothetical accident conditions (10CFR71, Appendix $B$ ). Credit could be taken for the Super Tiger to provide physical protection and fire protection for the FRP; no credit could be taken for leak tightness. 
A request for exemption addressing the above items was submitted to the NRC and an exemption was granted based on Westinghouse acceptance of the following conditions:

(a) Glove box surfaces shall be decontaminated to a smearable level of no more than $150,000 \mathrm{dpm} / 100 \mathrm{~cm}^{2}$ prior to fixation.

(b) After fixation, glove box surfaces shall have a sinearable level of contamination of no greater than $10,000 \mathrm{dpm} / 100$ $\mathrm{cm}^{2}$.

(c) The glove box shall be enclosed in a tight-fitting box constructed of one-inch plywood (FRP in our case).

(d) The space between the glove box and the FRP shall be filled with polyurethane foam so as to cocoon the glove box.

(e) The package shall be 1 imited to a maximum of 5 grams of plutonium.

The exemption covered the utilization of Super Tigers owned by DOE (Richland Operations Office), U.S. Ecology Company and Babcock and Wilcox. Subsequently, ARO contracted for the simultaneous use of these three Super Tigers and shipped 21 glove boxes from Cheswick to Richland, Washington under this exemption during the period February 7, 1981 to June 15, 1981. Table 2-5 sumnarizes the FPR shipments in Super Tiger. 


\begin{tabular}{|c|c|c|c|c|c|c|c|c|}
\hline \multicolumn{9}{|c|}{ TABLE $2-5$} \\
\hline \multirow{2}{*}{$\begin{array}{l}\text { SHIPMENT } \\
\text { NO. }\end{array}$} & \multirow{2}{*}{$\begin{array}{c}\text { DATE } \\
\text { SHIPPED }\end{array}$} & \multirow{2}{*}{$\begin{array}{l}\text { FRP } \\
\text { NO. }\end{array}$} & \multirow{2}{*}{$\begin{array}{l}\text { GLOVE BOX } \\
\text { IDENTITY }(1)\end{array}$} & \multirow{2}{*}{$\begin{array}{l}\text { GLOVE BOX } \\
\text { VOLUME } \\
\left(\mathrm{FT}^{3}\right)\end{array}$} & \multirow{2}{*}{$\begin{array}{c}\text { FRP } \\
\text { VOLUME } \\
\left(\mathrm{FT}^{3}\right)\end{array}$} & \multicolumn{2}{|c|}{ OUANTITY $(g)$} & \multirow{2}{*}{$\begin{array}{c}\text { TOTAL } \\
\text { ACTIVITY } \\
\text { (CURIES) }\end{array}$} \\
\hline & & & & & & $\mathrm{Pu}$ & $u^{235}$ & \\
\hline $\begin{array}{r}5 \\
6 \\
7 \\
8 \\
9 \\
10 \\
11 \\
12 \\
13 \\
14 \\
15 \\
17 \\
18 \\
19 \\
20 \\
21 \\
22 \\
23 \\
24 \\
27 \\
29\end{array}$ & $\begin{array}{l}2 / 7 / 81 \\
2 / 7 / 81 \\
2 / 16 / 81 \\
2 / 18 / 81 \\
2 / 25 / 81 \\
2 / 28 / 81 \\
3 / 6 / 81 \\
3 / 9 / 81 \\
3 / 11 / 81 \\
3 / 16 / 81 \\
3 / 17 / 81 \\
3 / 21 / 81 \\
3 / 26 / 81 \\
3 / 30 / 81 \\
4 / 7 / 81 \\
4 / 16 / 81 \\
4,22 / 81 \\
4 / 29 / 81 \\
5 / 1 / 81 \\
6 / 8 / 81 \\
6 / 15 / 81\end{array}$ & $\begin{array}{l}002 \\
003 \\
005 \\
006 \\
001 \\
007 \\
0083 \\
011 \\
019 \\
021 \\
010 \\
020 \\
017 \\
009 \\
016 \\
014 \\
018 \\
012 \\
015 \\
022 \\
013\end{array}$ & $\begin{array}{l}8-14 \\
8-10 \\
8-3 \\
8-3 \\
8-4 \\
8-7 \\
8-8 \\
8-9 \\
7-10 \\
8-6 \\
8-5 \\
7-9 \\
7-8 \\
8-11 \\
7-7 \\
7-1 \\
7-2 \\
7-4 \\
7-5 \\
7-3 \\
7-6\end{array}$ & $\begin{array}{r}107 \\
148 \\
148 \\
148 \\
148 \\
148 \\
148 \\
166 \\
130 \\
179 \\
166 \\
130 \\
130 \\
148 \\
130 \\
91 \\
130 \\
91 \\
130 \\
162 \\
91\end{array}$ & $\begin{array}{l}256 \\
305 \\
305 \\
305 \\
305 \\
305 \\
305 \\
337 \\
274 \\
333 \\
337 \\
274 \\
274 \\
305 \\
274 \\
202 \\
274 \\
202 \\
274 \\
322 \\
202\end{array}$ & $\begin{array}{l}.07 \\
.08 \\
.32 \\
.73 \\
.78 \\
.13 \\
.12 \\
.23 \\
.03 \\
.26 \\
.85 \\
.04 \\
.04 \\
.08 \\
.07 \\
.09 \\
.06 \\
.04 \\
.05 \\
.03 \\
.03\end{array}$ & $\begin{array}{l}.05 \\
.02 \\
.16 \\
1.10 \\
.74 \\
.19 \\
.14 \\
.38 \\
.01 \\
.34 \\
.95 \\
.03 \\
.03 \\
.05 \\
.05 \\
.05 \\
.15 \\
.03 \\
.04 \\
.03 \\
.01\end{array}$ & $\begin{array}{l}.10 \\
.11 \\
.42 \\
.96 \\
1.03 \\
.17 \\
.16 \\
.30 \\
.04 \\
.34 \\
1.12 \\
.05 \\
.05 \\
.11 \\
.09 \\
.12 \\
.08 \\
.05 \\
.07 \\
.04 \\
.04\end{array}$ \\
\hline \multicolumn{3}{|c|}{ TOTALS $(3)$} & & 2869 & 5970 & 4.13 & $4.45^{(4)}$ & 5.45 \\
\hline \multicolumn{9}{|l|}{ NOTES: } \\
\hline \multicolumn{9}{|c|}{$\begin{array}{l}\text { 1. Number before ciash indicates b } \\
\text { 2. Based on dimensions of maximun } \\
\text { 3. Total FRP's shipped }=21 \\
\text { 4. Equivalent to } 6 \text { arams total }\end{array}$} \\
\hline
\end{tabular}




\subsection{WASTE MANAGEMENT}

\subsubsection{GENERAL}

Radioactive waste generated during the D\&D Program at Cheswick was managed according to the scheme presented in Figure 2-11. Waste items were classified as "contaminated" or "clean" in accordance with the criteria specified for releasing materials for uncontrolled use in ANSI N13.12 (Oraft) and the facility operating license SNM-1120. Contaminated waste was further classified into transuranic (TRU) or nontransuranic (NONTRU) depending on whether the concentration of contaminants was greater or less than ten nanocuries of TRU elements per gram of waste matrix. Clean waste items were disposed of at a sanitary landfill while TRU and NONTRU waste was disposed of at the DOE burial grounds operated by RHO at Richland, Washington. TRU and NONTRU waste was packaged in accordance with burial site requirements (RHO-MA-222) and transportation regulations (10CFR7l and 49CFR 173.189). Transportation was conducted in accordance with the latter two regulations.

\subsubsection{TRU WASTE}

TRU waste was further classified into two categories: solid and liquid. Transportation regulations prohibited the shipment of liquid TRU waste; therefore, it was immobilized or converted to a solid form. Organic liquids were absorbed on a suitable absorber (Speedi-Dri) and aqueous (inorganic) liquids were solidified in concrete.

Solid TRU waste was segregated into combustible or noncombustible, a requirement of the burial ground. The equivalent categories per transportation regulations were "soft" and "hard", respectively. These two categories of waste could not be mixed within the same burial packages.

\section{CONTAINER AND PACKAGE DESCRIPTIONS}

The following three containers (as described in the previous section) were used for the disposal of TRU waste: the DOT 17C drum, the ANL M-III bin, and the ARD-designed FRP plywood box. All packages and packaging methods were 


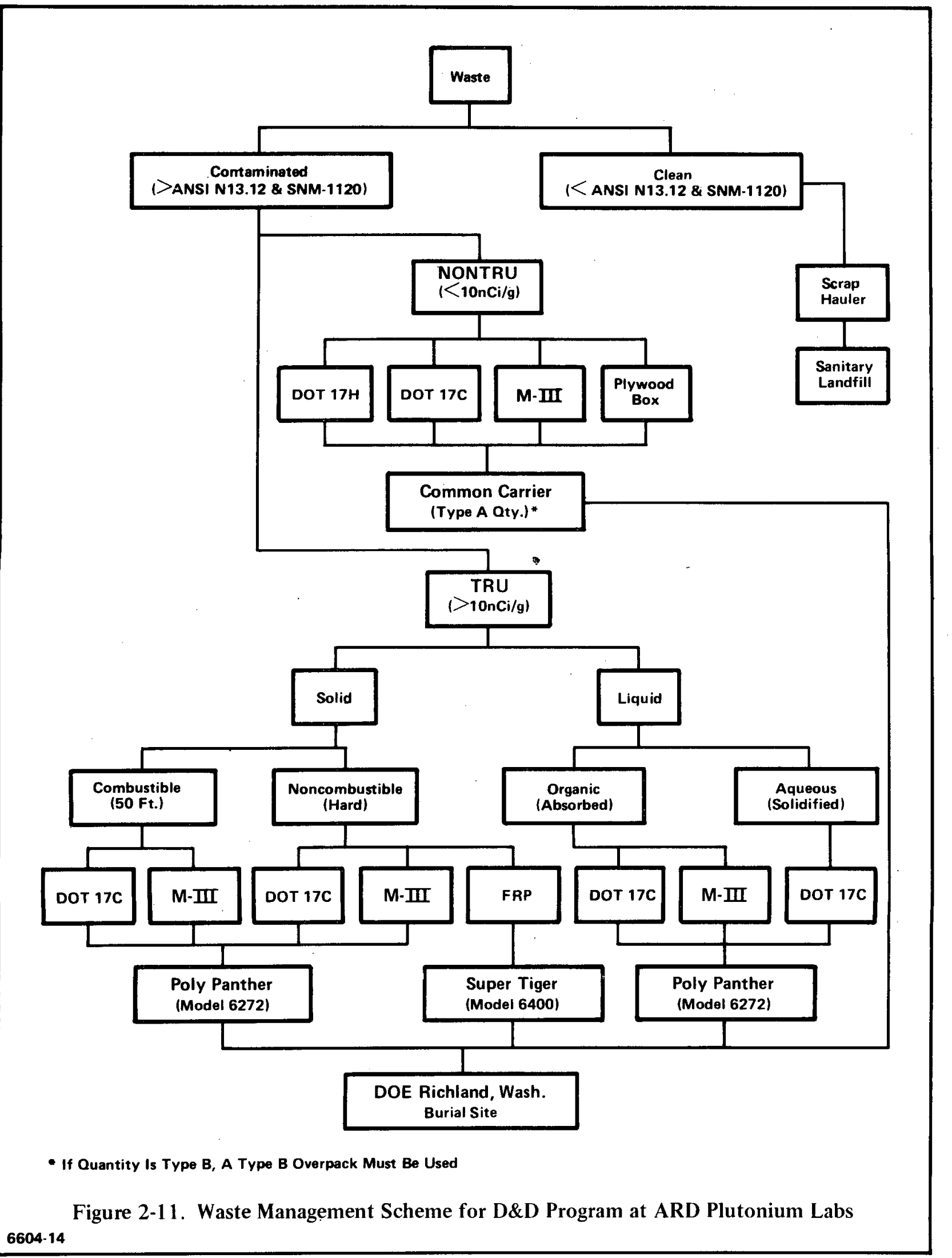


submitted to RHO for approval in accordance with RHO-MA-222. Attachments 7,8 and 9 contain a copy of each, as required for package approval, complete with engineering drawings where applicable.

A. DOT $17 C$ Drum

The DOT $17 \mathrm{C}$ container is a 55 gallon $\left(7.5 \mathrm{ft}^{3}\right.$ nominal), 16 gauge steel drum with nominal dimensions of 24 inches in dianeter by 35 inches high, fabricated per DOT Spec 17C. In addition, the drum was hot-dip galvanized in accordance with RHO-MA-222 to provide corrosion resistance for 20 -year retrievability. The DOT $17 \mathrm{C}$ drum also meets DOT Spec $7 A$ requirements for Type A general packaging. It was the only container listed in RHO-MA-222 as approved for direct burial of TRU waste generated by a off-site waste generator at the outset of the $D \& D$ program. This container was used for combustible (soft) and noncombustible (hard) solid TRU waste; absorbed organic liquid and solidified-in-concrete aqueous liquid TRU waste.

Combustible (soft) waste items were double-bagged in 12-mil thick, heat-sealed, PVC plastic bagging material and placed inside the DOT $17 C$ drum line with a $12-m i l$ thick, heat-sealed PVC drum liner. A total of 120 drums of this category were packaged and shipped.

The noncombustible (hard) waste items were wiped or brushed clean, sharp edges and protrusions were padded with polyethylene foam and tape, and the item was double-bagged in 12-mil heat-sealed PVC bagging material. The packages were then loaded into a DOT 17C drum prefoamed with a two-inch annular thickness and three-inch end thickness (top and bottom) of polyurethane foam. The drum was lined with a 12-mil, heat-sealable PVC liner prior to foaming. The effective volume of a prefoamed drum was reduced from 55 to 30 gallons, a reduction of $45 \%$. The use of polyurethane foam was a requirement of the Certificate of Compliance for the Super Tiger and was eliminated once the decision to use the Poly Panther for drum transport was made (see section II.D.E.2). A total of 85 druins of this category were packaged and shipped; 59 were prefoamed drums and 26 were not. 
Organic liquid TRU waste (lubricant, hydraulic fluids) was absorbed on a quantity of absorbent equivalent to twice that required to completely absorb the liquid. The absorbed liquid was then placed into one gallon polyethylene bottles with screw-top caps. The bottles were then double-bagged in 12-mil thick, heat-sealed PVC and placed in prefoamed drums lined with a 12-mil, heat-sealable PVC liner. Nine drums of absorbed organic liquid TRU waste were packaged in this manner.

Inorganic aqueous liquid TRU waste was solidified in concrete in a 30 gallon plastic fiber pack. The fiber pack was heat-sealed within a 12-mil PVC bag which in turn was centered within a 55 gallon DOT 17C drum lined with a 12-mil heat sealable liner and filled with absorbent. Eighteen drums of solidified aqueous liquid TRU waste were packaged in this manner.

B. M-III Bin

The M-III bin is a top loading steel box with nominal dimensions of 50 in length $\times 58$ in width $\times 72$ in height fabricated from 12-gauge carbon steel sheet metal per ANL drawing CS-E-2273. It has been tested and qualified as a Type A container per DOT Spec $7 \mathrm{~A}$ requirements. This container was used for combustible (soft) and noncombustible (hard) solid TRU waste as well as absorbed organic 1 iquids. It should be noted that the M-III bin was overpacked in a $7 \mathrm{ft} \times 7 \mathrm{ft} \times 6 \mathrm{ft}$ CSB fabricated per RHO Drawing $\mathrm{H}-2-91888$, prior to burial. This effectively doubled the burial volume.

Combustible waste items were placed within two heat-sealed 12-mil thick PVC bags which in turn were placed into the M-III bin. Five bins of this category were packaged and shipped. 
Noncombustible waste items too large for 55 gallon drums, were wiped clean, sharp corners and protrusions were padded with polyethylene foam and tape, and placed within two heat-sealed, 12-mil thick PVC bags prior to loading into the M-III bins. Foam-in-place polyurethane foam was used to prevent objects from shifting during handling and transportation. Twenty-nine bins of this category were packaged and shipped.

Organic liquid TRU waste was absorbed on twice the absorbent necessary to completely absorb the liquid. The waste was then placed in one-gallon polyethylene bottles and double-bagged in 12-mil heat-sealable PVC. The packages were then placed in either DOT $17 H$ or DOT 17C drums lined with 12-mil thick, heat-sealable PVC liners and the void space was filled with absorbent. The drums were then placed into the M-III bin. One bin, containing seven drums was packaged and shipped in this manner.

\section{FRP Plywood Box}

The FRP plywood box is described on ARD Drawing 1620E43, Sub. 3 and was designed in accordance with Appendix E of RHO-MA-222. The design report for the FRP can also be found in Attachment 8 . Briefly, the FRP is constructed of one-inch plywood sheathing reinforced with $4 \times$ $4 \mathrm{~s}$ on 12 -inch centers in the sidewalls and $4 \times 6 \mathrm{~s}$ (double $2 \times 6 \mathrm{~s}$ ) on 8-inch centers in the top and bottom. Five $4 \times 4$ s are also attached to the bottom to provide a skid for handling purposes. The top and front panels of the FRP were removable to facilitate glove box loading. All joints were made by gluing and nailing per drawing requirements. The exterior of the FRPS is completely coated with a $1 / 8$ inch thick layer of fiberglass reinforced polyester per Specification E-955048. Seven different styles of FRPS were designed, each custom-fitted to a particular style glove box. The FRP was used exclusively for packaging TRU contaminated glove boxes. 
To prepare a glove box for loading into an FRP, all equipment and utility services were removed and the internal surfaces of the box were decontaminated to less than $150,000 \mathrm{dpm} / 100 \mathrm{~cm}^{2}$ smearable alpha activity using NUTEK EL-600 decon solution. The internal surfaces were then sprayed with several coats of "clear coat" polyvinyl alcohol fixative until the smearable alpha activity was

less than' $10,000 \mathrm{dpm} / 100 \mathrm{~cm}^{2}$. Prior to $\mathrm{fixing}$, all glove boxes and bags were replaced with clean PVC bag stubs and all feed-through openings were plugged. Subsequently, the glove ports and bag ports were covered with protective covers. The glove box was then separated from the ventilation system and non-destructively assayed (NDA) for plutonium content. Each glove box was limited to five grams plutonium by the transportation exemption granted by the NRC.

The top and front panels of the FRP were removed and the glove box was loaded into the FRP through the front using a forklift. The glove box was centered within the FRP and all voids between the glove box and the FRP were completely filled with foam-in-place polyurethane foam. This was done in such a manner as to completely cocoon the glove box in polyurethane foam with a minimum thickness of $1 / 2$ inch. The front and top panels were reinstalled at the proper time in this sequence by gluing and nailing. All glued joints were clamped until the adhesive cured. The seams of the top and front panels were sealed by applying several layers of fiberglass polyester by the "hand layup" method to a thickness of $1 / 8$ inch minimum. This resulted in a waterproof package completely encased within a $1 / 8$ inch layer of reinforced polyester with a design lifetime of 20 years after burial. Twenty-one glove boxes were packaged in this manner.

\section{TRANSPORTATION OVERPACKS}

The nature of the TRU waste generated during the D\&D of the Cheswick facility was such that practically every individual waste package contained greater than Type B quantities (>0.001 curies) of plutonium. In accordance with 1OCFR71 and 49CFR 173.389, the transportation of such shipments required the 
use of Type B transportation overpacks. Two such overpacks were utilized throughout this program; namely the Poly Panther (Model 6272) and the Super Tiger (Model 6400).

\section{A. Poly Panther}

The Poly Panther (Model 6272) is a Type B transportation overpack certified by the NRC under Certificate of Compliance No. 6272. There are only six Poly Panthers in existence and all are owned by U.S. Ecology Company. All six Poly Panthers are mounted on one flat-bed tractor trailer.

Originally, it was intended to use the Poly Panther for transporting only M-III bins. Subsequently, its use was extended also to the shipment of DOT $17 \mathrm{C}$ drums. This was accomplished by packaging eight drums in M-III bins which were unloaded at the burial site and returned for reuse. Eleven shipments comprised of $35 \mathrm{M}$-III bins (Plus 1 NONTRU bin) and 232 drums of TRU waste were transported in the Poly Panther.

B. Super Tiger

The Super Tiger (Model 6400) is a Type B transportation overpack cert if ied by the NRC under Certificate of Compliance No. 6400. ARO used the Super Tiger to overpack the FRP for transportation under an exemption granted by the NRC (see previous section). Three Super Tigers were contracted for use, one each from U.S. Ecology Company, Babcock and Wilcox and the DOE/ROO. Twenty-one Super Tiger shipments were made. 


\section{SUMMARY OF WASTE SHIPMENTS}

Information for shipments of TRU waste is summaried for DOT 17C drums, M-III bins and FRPs in Table 2-6. Eleven Poly Panther and 21 Super Tiger shipments were made to the DOE/Richland, Washington burial site from the ARD Cheswick Site beginning on September 29, 1980 and ending on October 6, 1981. The shipments consisted of 232 DOT 17C drums, 35 ANL M-III bins (plus 1 NONTRU bin) and 21 FRPs with a total burial volume of $16,530 \mathrm{ft}^{3}$ and 1006 curies of radioactivity.

\begin{tabular}{|c|c|c|c|c|c|c|}
\hline \multicolumn{7}{|c|}{ TABLE 2-6 } \\
\hline \multirow[t]{2}{*}{ PACKAGE } & \multirow{2}{*}{$\begin{array}{l}\text { SUANTITY } \\
\text { SHIPPED }\end{array}$} & \multirow{2}{*}{$\begin{array}{r}\text { WASTE } \\
\text { VOLUME } \\
\left(\mathrm{FT}^{3}\right)\end{array}$} & \multirow{2}{*}{$\begin{array}{l}\text { BURIAL }(1) \\
\text { VOLUME } \\
\left(F^{3}\right)\end{array}$} & \multicolumn{2}{|c|}{ QUANTITY } & \multirow{2}{*}{$\begin{array}{l}\text { ACTIVITY } \\
\text { (CURIES) }\end{array}$} \\
\hline & & & & Fiu & 1 & \\
\hline $\begin{array}{l}\text { DOT } 17 \mathrm{C} \\
\text { (55 gal. drums) }\end{array}$ & 232 & $1539^{(2)}$ & 1740 & $44 i$ & 335 & 517 \\
\hline ANL M-III Bins & $35^{(3)}$ & $4375^{(4)}$ & $8820^{(5)}$ & 416 & 378 & 484 \\
\hline FRP's & 21 & $2869^{(6)}$ & 5970 & 4 & 6 & 5 \\
\hline TOTALS. & 288 & 8783 & 16,530 & 862 & 1319 & 1006 \\
\hline \multicolumn{7}{|l|}{ NOTES } \\
\hline \multicolumn{7}{|c|}{ 1. Based on external dimensions of burial package } \\
\hline \multicolumn{7}{|c|}{ 3. In addition, $1 \mathrm{M}$-III bin containing $125 \mathrm{ft}^{3}$ of NONTRU waste was shipped } \\
\hline \multicolumn{7}{|c|}{ 4. Based on $125 \mathrm{ft}^{3}$ per M-III bin } \\
\hline \multicolumn{7}{|c|}{ 5. Based on $252 \mathrm{ft}^{3}$ per $\operatorname{CSB}$} \\
\hline \multicolumn{7}{|c|}{ 6. Based on dimensions of maximum envelope occupied by glove box } \\
\hline
\end{tabular}


The residual amount of plutonium and uranium, determined to be present in the waste by non-destructive assay, was found to be 862 grams and 1319 grams respectively. The majority of the contamination was contained in the drums and $M-I I I$ bins since little or no effort (other than wiping and brushing) was made to decontaminate items shipped in these packages. On the other hand, glove boxes were decontaminated to less than $150,000 \mathrm{dpm} / 100 \mathrm{~cm}^{2}$ alpha activity prior to packaging in FRPs to meet the requirements of the NRC exemption granted for use of the Super Tiger. The benefit of this decontamination effort is reflected in the small total activity of 5 curies for the FRPS.

It is also interesting to note that the burial volume for M-III bins and FRPS is utwo times the actual waste volume. In the case of the M-III bins, this is a direct result of the use of CSBs as burial overpacks. Similarly, for the FRPs the factor of two increase in volume can be principally attributed to dimensional growth of the package associated with the redesign effort required to demonstrate that the package could sustain burial loads without resorting to external shoring.

\section{5 .3 NONTRU WASTE}

With the exception of one M-III bin, no NONTRU waste was generated during the D\&D program. NONTRU waste is defined in RHO-MA-222 as "radioactive wastes known to contain less than 10 nanocuries of transuranic contamination per gram of waste matrix," a volumetric concentration. Also, the use of the term, "matrix" implies a uniform distribution. Since all of the waste generated was surface contaminated and therefore did not meet the requirement for uniform distribution, it was classified as TRU.

The M-III bin, which was classified as NONTRU, contained equipment that otherwise could have been released for uncontrolled use (that is, $<20$ $\mathrm{dpm} / 100 \mathrm{~cm}^{2}$ smearable and $<220 \mathrm{dpm} / 100 \mathrm{~cm}^{2}$ fixed) except that it contained inaccessible areas. 
It is interesting to note that even if one assumed that the residual activity of the glove boxes was uniformly distributed, the concentration of TRU would have been $2100 \mathrm{nCi} / \mathrm{g}$ for the "cleanest" glove box, a factor of ten above the NONTRU limit. This is true, despite the fact that excessive decontamination effort was expended on the glove boxes.

\subsubsection{CLEAN WASTE}

A considerable volume of waste was released as clean and was disposed of at sanitary landfills. The waste was processed in accordance with PFDL-AP-0013 (Attachment 9), which was based on limits set forth in ANSI N13.12 and the facility license SNM-1120. PFDL Form \#097 (included in Attachment 5) was filled out for every item and is currently on file. In order to be classified as "clean," an item must meet the following:

A. Smearable alpha* contamination must be $<20 \mathrm{dpm} / 100 \mathrm{~cm}^{2}$

B. Total alpha* activity: $<300 \mathrm{dpm} / 100 \mathrm{~cm}^{2}$ (maximum) $<100 \mathrm{dpm} / 100 \mathrm{~cm}^{2}$ (average)

C. Maximum dose rate at one $\mathrm{cm}$ from surface: $<1.0 \mathrm{mrad} / \mathrm{hr}$ (maximum) $<0.2 \mathrm{mrad} / \mathrm{hr}$ (average)

*Although os activity limits also exist, these limits are 50 times the $\alpha$ limits while the maximum $s /$ a ratio for any fuel material processed never exceeded 34. Thus a activity levels are limiting. For further discussion see Section 4.2.1.1. 


\subsection{RADIATION EXPOSURE OF PERSONNEL}

\subsubsection{PERSONNEL EXPOSURE TO EXTERNAL RADIATION}

The radiation exposure history for external exposure of all personnel operating under License SNM-1120 is summarized in Tables 2-7 through 2-11 for the period January, 1975 through December, 1980. Principal activities during this period are briefly summarized in Table 2-9. From the last entries in this table, it can be seen that the bulk of the decontamination effort for decommissioning ARD facilities occurred during the latter part of 1979, during all of 1980, and was completed during the first seven months of 1981. Although similar exposure data are not readily available yet for the 1981 calendar year, this downward trend during the period 1978 through 1980 indicates that substitution of the 1979 and 1980 data for those of the mid 1979 through mid 1981 period should be a conservative overestimate of the actual situation.

Personnel exposure to external sources of beta/gamma radiation was monitored by thermoluminescent dosimeter (TLD) badges worn by individuals. These badges were changed once per month for most of the technicians and once per quarter for other personnel. The criteria for frequency of change was based on the potential for the exposure level to approach the quarterly limit. These TLDs were evaluated by an outside vendor (Eberline Instrument Corporation). Tables 2-7 and 2-8 provide a breakdown of the exposure history for the facility.

Table 2-7 shows the distribution of radiation exposure of all personnel in terins of percent of personnel in each dose rate range for the years 1975 through 1980. For comparison purposes, similar information is shown for personnel in all U.S. fuel fabrication and processing facilities. Reviewing this table shows that the distribution of exposures for SNM-1120 has been on a trend towards the lower exposure ranges over the past five years, but no significant difference is noted between 1978 and 1980, the period during which $D \& D$ activities were going on. The distribution for SNM-1120 in 1980 is comparable to the overall industry for 1977 (which is the latest data 
available) with the exception that there were no exposures greater than 0.75 rem for SNM-1120 operations, whereas $5.4 \%$ of the persons exposed in the industry as a whole were over 0.75 rem.

\begin{tabular}{|c|c|c|c|c|c|c|c|c|c|}
\hline \multicolumn{10}{|c|}{$\begin{array}{c}\text { TABLE } 2-7 \\
\text { RADIATION EXPOSURE HISTORY } \\
\text { COMPARISON OF SNM-1120 TO ALL FACILITIES }\end{array}$} \\
\hline \multirow{2}{*}{$\begin{array}{l}\text { Exposure } \\
\text { Range } \\
\text { (rem) }\end{array}$} & \multicolumn{3}{|c|}{$\begin{array}{c}\text { All Fuel Processing \& } \\
\text { Fabrication Facilities } \\
\% \text { of Total } \\
\end{array}$} & \multicolumn{6}{|c|}{$\begin{array}{c}\text { SNM- } 1120 \text { Operations } \\
\% \text { of Total }\end{array}$} \\
\hline & 1975 & 1976 & 1977 & 1975 & 1976 & 1977 & 1978 & 1979 & 1980 \\
\hline $\begin{array}{l}\text { Less Than } \\
\text { Measurable }\end{array}$ & 51.8 & 53 & 39 & 32.7 & 49.5 & 52.7 & 45.9 & 52.4 & 57.4 \\
\hline$=0.10$ & 17.3 & 25 & 39 & 21.4 & 17.8 & 11.8 & 28.8 & 25.2 & 25.5 \\
\hline $0.10-0.25$ & 9.66 & 9 & 9 & 11.2 & 8.91 & 11.8 & 10.8 & 6.8 & 11.7 \\
\hline $0.25-0.50$ & 8.95 & 5 & 5 & 9.18 & 7.92 & 9.09 & 8.1 & 5.8 & 4.3 \\
\hline $0.50-0.75$ & 3.80 & 3 & 3 & 4.08 & 1.98 & 3.64 & 2.7 & 5.8 & 1.1 \\
\hline $0.75-1.0$ & 2.11 & 2 & 2 & 1.02 & 7.92 & 4.55 & 0.9 & 1.0 & - \\
\hline $1-2$ & 3.34 & 2 & 2 & 8.16 & 5.94 & 6.36 & 2.7 & 2.9 & - \\
\hline $2-3$ & 1.34 & 1 & 1 & 9.18 & - & - & - & - & - \\
\hline $3-4$ & 0.68 & 0.4 & 0.2 & 3.06 & - & - & - & - & - \\
\hline $4-5$ & 0.35 & 0.2 & 0.2 & - & - & - & - & - & - \\
\hline $5-6$ & 0.26 & 0.2 & - & - & - & - & - & - & - \\
\hline $6-7$ & 0.10 & - & - & - & - & - & - & - & - \\
\hline $7-8$ & 0.08 & - & - & - & - & - & - & - & - \\
\hline $8-9$ & 0.12 & & & & & & & & \\
\hline $9-10$ & 0.13 & & & & & & & & \\
\hline $10-11$ & - & & & & & & & & \\
\hline- & & & & & & & & & \\
\hline
\end{tabular}

Table 2-8 provides the same information for SNM-1120 operations but is broken down in greater detail by job function, year, and exposure range. In order to apply this information, it is important to recognize the variations in workload that have occurred since 1975 for the laboratory. A summary of the major activities is presented in Table 2-9 as related to radiation protection considerations. 


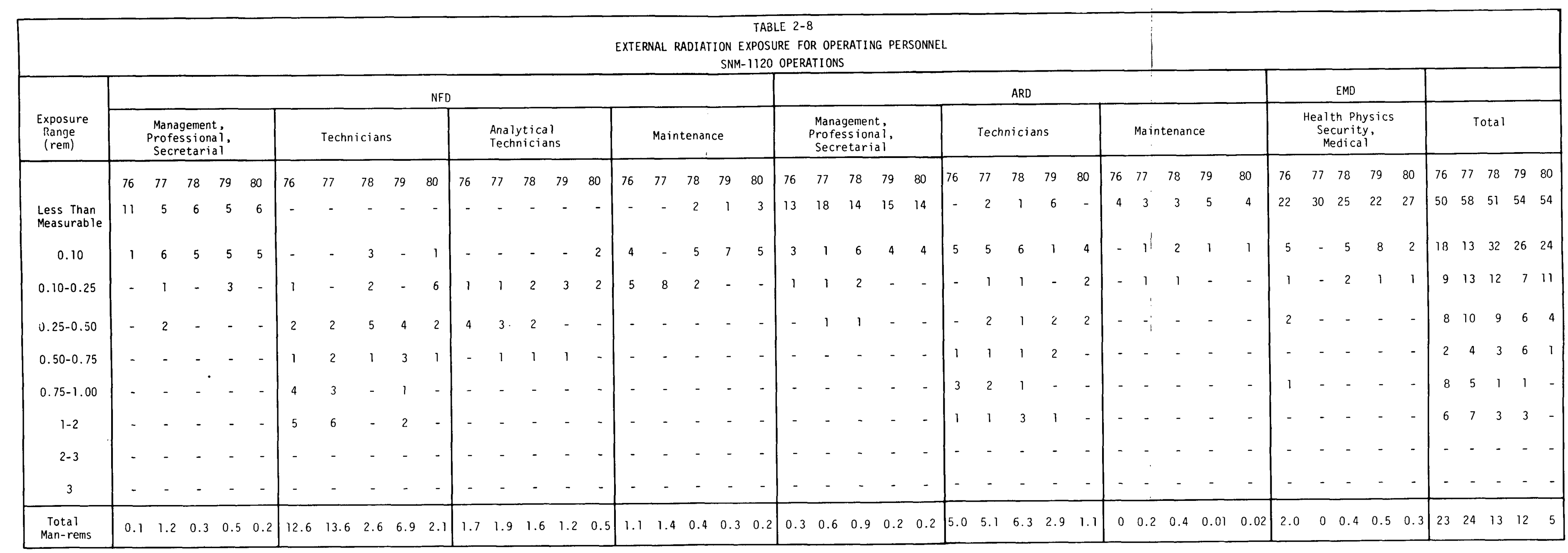




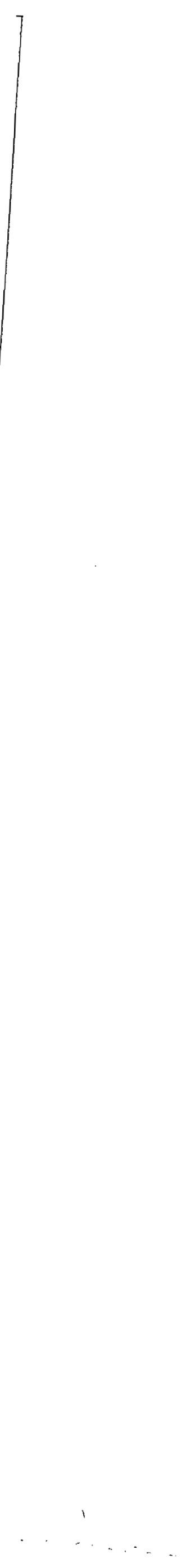


TABLE $2-9$

SUMMARY OF PFIHCIPAL OPERATIONS

1975 During this year, MFD fabricated the TRINO fuel. This plutonium had the highest $\mathrm{Pu}^{24} 1$ content and therefore had the highest radiation levels associated with it. ARD converted their facility to carbide fuel fabrication and began fabrication work wi h plutonium towards the end of the year.

1976 NFO did not fabricate any fuel during the year. Shielding material in the form of vinyl-lead and leaded glass was added to many NFD boxes. ARD continued fabrication of carbide fisel pins for test pin radiation experiments.

1977 NFD fabricated the NOK fuel during the year. ARD continued fuel pin fabrication through the year.

A study was undertaken about mid-year to identify and quantify the radiation exposure associated with each step in the ARD operation.

1978 NFD did not fabricate any fuel during the year. ARD fabricated a relatively large quantity of fuel during the year. About mic-year ARO converted over to using the higher exposure level plutonitu?

1979 During the first thrce quarters, IFD concentrated on gross cleanup of :llove boxes as part of the facility decontamination effort. The last quarter involved primarily a scrap recovery run in preparation for returning material. AP.D continued fabrication of fuel pins through mid year using a higher burnup plutoni um fuel. Tovards the end of the year, ARD operations began to focus on cleaning riove boxes and packaging fuel for shipping off site.

1980 The bulk of the fuel inventory was removed in the first quarter of 1980. Gross contamination and removal of glove boxes in the ARD lab in Building 8 look place during the last three quarters.

The most significant means to review the detailed breakdown in Table $2-8$ is to focus on the total exposure in units of man-rems, which is presented in the bottom row. Table 2-10 summarizes this same information but as a percentage of the total man-rems for each grouping of personnel. 
Considering Table 2-10, it is clear that the combination of NFD and ARD technicians accounts for about $70 \%$ to $80 \%$ of the total exposure for the operations. These two groups constitute only about $20 \%$ of the total work force. The next most important group is the analytical technicians who account for about $10 \%$ of the total exposure. The group constitutes about $5 \%$ of the total work force. The other groups represent a small fraction of the total exposure.

\begin{tabular}{|c|c|c|c|c|c|c|}
\hline \multicolumn{7}{|c|}{$\begin{array}{c}\text { TABLE 2-10 } \\
\text { BREAKDOWN OF TOTAL MAN-REM } \\
\text { RADIATION EXPOSURE BY JOB FUNCTIONS }\end{array}$} \\
\hline \multirow{2}{*}{ Div. } & \multirow{2}{*}{ Job Functions } & \multicolumn{5}{|c|}{ Percent of Total Man-Rems } \\
\hline & & 1976 & 1977 & 1978 & 1979 & 1980 \\
\hline \multirow{4}{*}{ NFD } & $\begin{array}{l}\text { Management, } \\
\text { Professional, } \\
\text { Secretarial }\end{array}$ & $<1$ & 5 & 2 & 4 & 4 \\
\hline & Technicians & 55 & 57 & 20 & 55 & 46 \\
\hline & $\begin{array}{l}\text { Analytical } \\
\text { Technicians }\end{array}$ & 7 & 8 & 12 & 10 & 11 \\
\hline & Maintenance & 5 & 6 & 3 & 2 & 4 \\
\hline \multirow{3}{*}{ ARD } & $\begin{array}{l}\text { Management, } \\
\text { Professional, } \\
\text { Secretarial }\end{array}$ & 1 & 2 & 7 & 2 & 4 \\
\hline & Technicians & 22 & 21 & 49 & 23 & 24 \\
\hline & Maintenance & $<1$ & 1 & 3 & $<1$ & $<1$ \\
\hline EMD & $\begin{array}{l}\text { Health Physics, } \\
\text { Security, } \\
\text { Medical }\end{array}$ & 9 & $<1$ & 3 & 4 & 6 \\
\hline
\end{tabular}


During 1980 the exposure dropped to five man-rem, which is about one-fifth of the exposure during the NOK fuel fabrication job in 1977 . The first quarter of 1980 involved the bulk removal of fuel inventory. The last three quarters of the year included a significant portion of time on gross decontamination of glove boxes for the decontamination and decommissioning of the ARD facility in Building 8 .

The ARD technicians' man-rem exposures were essentially 5, 6, 3, and 1 man-rem for the years 1977, 1978, 1979, and 1980, respectively. The drop in total exposure from 1979 to 1980 can possibly be accounted for by the significant reduction in fuel inventory.

The NFD analytical technicians' exposure remained essentially constant at about one to two man-rems over the four-year period (1976 through 1979). There was a drop from 1.6 man-rem in 1978 to 1.2 man-rem in 1979, but this was primarily due to the loss of one technician. Another significant drop (from 1.2 to 0.5 man-rem) is evident for 1980 versus 1979. This latter drop in exposure level is most likely due to the lower concentration level of the fue? materials (waste concentration versus solid fuel concentration).

The total man-rems for all of SNM-1120 operations is summarized in Table 2-11 along with comparative data for the industry as a whole. Total man-rem exposures have ranged from 55 man-rems in 1975 to five man-rems in 1980 . These data show a significant incremental reduction in external exposure between the years 1977 and 1978 and between 1979 and 1980 . The reduction during 1980 is attributed mainly to the reduction in fuel inventory.

In comparison to the overall industry, the average exposure (see Table 2-11) to an individual under SNM-1120 operations during 1979 and 1980 has been about the same as that for the overall industry in 1977 (which is the latest year for which data is available). Although such a comparison is superficial, it does help to put the information into perspective. In 1980, the average incremental occupational exposure to all personnel involved in SNM-1120 operations was 50 mrem, which is less than half of what could be considered the background radiation exposure for the area. If only those persons who 
received a measurable exposure are included, then the average incremental exposure to those persons in 1980 was $130 \mathrm{mrem}$, which is about equal to the background radiation exposure. The maximum dose received by any single individual during 1980 was 750 mrem. Considering only the NFD and ARD analytical laboratory technicians, the average incremental exposure in 1980 was 170 mrem.

\begin{tabular}{|c|c|c|c|c|c|c|c|}
\hline \multicolumn{8}{|c|}{$\begin{array}{c}\text { TABLE } 2-11 \\
\text { RADIATION EXPOSURE HISTORY }\end{array}$} \\
\hline \multirow{2}{*}{ Category } & \multirow{2}{*}{ Year } & \multirow{2}{*}{$\begin{array}{l}\text { Number of } \\
\text { Facilities }\end{array}$} & \multirow{2}{*}{$\begin{array}{l}\text { Number of } \\
\text { Individuals } \\
\text { Monitored }\end{array}$} & \multirow{2}{*}{$\begin{array}{l}\text { Total } \\
\text { Number of } \\
\text { Man-Renis }\end{array}$} & \multirow{2}{*}{$\begin{array}{l}\text { Average } \\
\text { Number of } \\
\text { Man-Remls } \\
\text { Per Facility }\end{array}$} & \multicolumn{2}{|c|}{$\begin{array}{c}\text { Average Exposure Per } \\
\text { Individual, Rem }\end{array}$} \\
\hline & & & & & & $\begin{array}{c}\text { All } \\
\text { Exposures }\end{array}$ & $\begin{array}{l}\text { Measurable } \\
\text { Exposures }\end{array}$ \\
\hline \multirow{5}{*}{$\begin{array}{l}\text { Fuel Pro- } \\
\text { cessing and } \\
\text { Fabrication }\end{array}$} & 1977 & 20 & 11,496 & 1,725 & 86 & 0.15 & 0.25 \\
\hline & 1976 & 21 & 11,227 & 1,830 & 87 & 0.16 & 0.35 \\
\hline & 1975 & 23 & 11,405 & 3,125 & 136 & 0.27 & 0.56 \\
\hline & 1974 & 25 & 10,921 & 2,739 & 110 & 0.25 & 0.59 \\
\hline & 1973 & 27 & 10,610 & 2,400 & 89 & 0.23 & 0.47 \\
\hline \multirow[t]{6}{*}{ SivM-1120 } & $19: 0$ & 1 * & 94 & 5 & 5 & 0.05 & 0.13 \\
\hline & 1979 & $1 *$ & 103 & 12 & 12 & 0.12 & 0.25 \\
\hline & 1978 & $1 *$ & 111 & 13 & 13 & 0.12 & 0.22 \\
\hline & 1977 & $1 *$ & 110 & 24 & 24 & 0.22 & 0.47 \\
\hline & 1976 & $1 *$ & 101 & 23 & 23 & 0.23 & 0.46 \\
\hline & 1975 & $T^{*}$ & 98 & 55 & 55 & 0.56 & 0.83 \\
\hline
\end{tabular}

Overall, the trend in both total facility man-rems and average exposures has been downward. This overall downward trend of external exposures is expected to continue since, under the facility D\&D efforts, the plutonium is being removed from the facility and the glove boxes are being cleaned up in preparation for eventual disposal. Although significant manpower was required in cleaning the glove boxes, the experience during 1980 in cleaning the ARD boxes indicates that this did not result in a large man-rem exposure. 


\subsubsection{PERSONNEL EXPOSURE TO INTERNAL RADIATION}

The potential for exposure to internal sources of radiation is monitored primarily by an air sampling program within the facility. Bioassay samples are taken as needed as an independent verification of program effectiveness.

AIR SAMPLING PROGRAM

Approximately 22,000 air samples are taken and analyzed annually to monitor air within the working environment. Given the total containment concept within a plutonium facility, the bulk (about 99.7\%) of these air samples over the past five years has been less than the maximum permissible concentration (MPC) allowed by the regulations. The majority of these room samples measured fell below the minimum detectable activity (MDA) concentration of $2 \times 10^{-13}$ $\mathrm{\mu C} \mathrm{i} / \mathrm{CC}(1)$, which corresponds to $10 \%$ of the occupational MPC for the soluble forms of plutonium or $0.5 \%$ of the occupational MPC for the insoluble forms of plutonium. Approximately $40 \%$ of the room air samples taken are in areas where the soluble form of plutonium would be expected. The remaining $60 \%$ are in areas where insoluble forms of plutonium would be expected.

Whenever an air sample is obtained within the laboratories that is greater than an established action level, (2) an "air sample investigation form" is completed which establishes a managenent review of the situation and notes any corrective actions taken.

(1) In the first quarter of 1980 a new counting systeln was set up which resulted in even lower values of minimum detectable activity. Since approximately February, 1980 the MDA values for room air have been $1.1 \times 10^{-13} \mu \mathrm{C} / \mathrm{CC}$ or $5.5 \%$ of the occupational MPC for soluble forms of plutonium and $0.3 \%$ of insoluble forms.

(2) The action levels are taken as $50 \%$ of the MPC for soluble plutonium. 


\section{EXPOSURE HISTORY FOR AIRBORNE CONTAMINATION}

Historical data on the number of daily air samples for which the airborne alpha concentration exceeded the action levels are summarized in Table 2-12. This table lists information on both the number of air sample investigations conducted and the number of individual air samples involved. The bottom row of information puts this data into perspective by showing what percentage of the total number of air samples taken in each area was greater than the action level.

\begin{tabular}{|c|c|c|c|c|c|c|c|c|c|c|c|}
\hline \multirow[b]{4}{*}{ Year } & \multicolumn{10}{|c|}{$\begin{array}{c}\text { TABLE 2-12 } \\
\text { SUMMARY OF AIR SAMPLES > ACTION LEVEL } \\
\text { FOR SNM-1120 OPERATIONS }\end{array}$} & \multirow{4}{*}{$\begin{array}{l}\text { Total Number } \\
\text { of Air Sample } \\
\text { Investigations } \\
\text { Conducted }\end{array}$} \\
\hline & \multicolumn{10}{|c|}{ Number of Daily Room Air Samples > Action Level } & \\
\hline & \multicolumn{2}{|c|}{ Building 7} & \multicolumn{7}{|c|}{ Building 8} & \multirow{2}{*}{$\begin{array}{l}\text { Total } \\
\text { Total Number (1) } \\
\text { of Air Samples } \\
>\text { Action Leve? }\end{array}$} & \\
\hline & $\begin{array}{c}\text { ARD } \\
\text { Pu Lab }\end{array}$ & U Lab & $\begin{array}{l}\text { North Lab } \\
\text { and } \\
\text { Addition }\end{array}$ & $\underset{\text { Lab }}{\text { Ceramics }}$ & $\begin{array}{l}\text { Chemical } \\
\text { Development } \\
\text { Lab }\end{array}$ & $\begin{array}{l}\text { Analytical } \\
\text { Lab }\end{array}$ & $\begin{array}{l}\text { ARD } \\
\text { Lab }\end{array}$ & $\begin{array}{l}\text { Wet } \\
\text { Oxide } \\
\text { Lab }\end{array}$ & $\begin{array}{l}\text { Penthouse } \\
\text { and Clean } \\
\text { Areas }\end{array}$ & & \\
\hline 1976 & 0 & 15 & 3 & 12 & 8 & 32 & 17 & 8 & 0 & 95 & 61. \\
\hline 1977 & 0 & 8 & 2 & 15 & 7 & 20 & 3 & 2 & 0 & 57 & 43 \\
\hline 1978 & 8 & 5 & 0 & 2 & 3 & 13 & 6 & 0 & 0 & 37 & 23 \\
\hline 1979 & 2 & 8 & 2 & 6 & 0 & 3 & 3 & 5 & 0 & 29 & 22 \\
\hline 1980 & 0 & 3 & 2 & 1 & 0 & 13 & 7 & 4 & 0 & 30 & 22 \\
\hline $\begin{array}{l}\text { Five } \\
\text { Year } \\
\text { Total }\end{array}$ & 10 & 9 & 9 & 36 & 18 & 81 & 36 & 19 & 0 & 248 & 168 \\
\hline $\begin{array}{l}\text { \% of } \\
\text { Total } \\
\text { Samples } \\
\text { Taken } \\
\text { In Area }\end{array}$ & $0.06 \%$ & $0.4 \%$ & $0.07 \%$ & $0.3 \%$ & $0.5 \%$ & $0.5 \%$ & $0.4 \%$ & $0.2 \%$ & $0 \%$ & $0.2 \%$ & \\
\hline
\end{tabular}

Some samples that are greater than the action level (which triggers the air sample investigation) do not exceed the appropriate MPC for each area. Table 2-13 summarizes the data for only those samples that were greater than MPC for each laboratory area. Again, the bottom row of information shows what percentage of the total number of air samples taken in each area was greater 
than MPC. It is also important to consider how much above MPC the individual samples were. This distribution is presented in the third column from the right-hand side of Table 2-13, which shows the number of samples that were one times MPC, two times MPC, etc. The last two columns of the table provide a figure-of-merit value, which is a weighted distribution to account for the magnitude of the individual samples.

\begin{tabular}{|c|c|c|c|c|c|c|c|c|c|c|c|c|c|}
\hline \multirow{4}{*}{ Year } & \multicolumn{13}{|c|}{$\begin{array}{c}\text { TABLE } 2-13 \\
\text { SUMMARY OF AIR SAMPLES > MPC } \\
\text { FOR SNM-1120. OPERATIONS }\end{array}$} \\
\hline & \multicolumn{10}{|c|}{ Number of Daily Room Air Samples > MPC } & \multirow{3}{*}{$\begin{array}{c}\text { Distribution } \\
(X M P C)\end{array}$} & \multirow{3}{*}{ * } & \multirow{3}{*}{$\star \star$} \\
\hline & \multicolumn{2}{|c|}{ Building 7} & \multicolumn{7}{|c|}{ PFDL } & \multirow{2}{*}{ 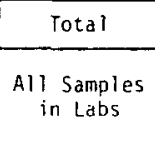 } & & & \\
\hline & $\begin{array}{l}\text { ARD } \\
\text { Pu Lab }\end{array}$ & U Lab & $\begin{array}{l}\text { North Lab } \\
\text { and } \\
\text { Addition }\end{array}$ & $\underset{\text { Lab }}{\text { Ceramics }}$ & $\begin{array}{c}\text { Chemical } \\
\text { Devel apment } \\
\text { Lab }\end{array}$ & $\begin{array}{l}\text { Analytical } \\
\text { Lab }\end{array}$ & $\begin{array}{l}\text { ARD } \\
\text { Lab }\end{array}$ & $\begin{array}{l}\text { ARD } \\
\text { Oxide } \\
\text { Lab }\end{array}$ & $\begin{array}{l}\text { Penthouse } \\
\text { and Clean } \\
\text { Areas }\end{array}$ & & & & \\
\hline 1976 & 0 & 4 & 0 & 0 & 0 & 21 & 2 & 8 & 0 & 35 & $\begin{array}{lr}1 x-12 & 4 x-4 \\
2 x-6 & 10 x-2 \\
3 x-10 & 100 x-1\end{array}$ & 190 & $1.0 \%$ \\
\hline 1977 & 0 & 2 & 0 & 3 & 3 & 17 & 0 & $i$ & 0 & 26 & $\begin{array}{l}1 x-12 \quad 10 x-2 \\
2 x-11 \\
4 x-1\end{array}$ & 58 & $0.3 \%$ \\
\hline 1978 & 1 & 3 & 0 & 0 & 1 & 11 & 0 & 0 & 0 & 16 & $\begin{array}{ll}1 x-7 & 4 x-1 \\
2 x-5 & 5 x-1 \\
3 x-2 & \end{array}$ & 32 & $0.2 \%$ \\
\hline 1979 & 0 & 4 & 0 & 1 & 0 & 2 & 0 & 4 & 0 & 11 & $\begin{array}{l}1 x-8 \\
2 x-3\end{array}$ & & \\
\hline 1980 & 0 & 1 & 0 & 0 & 0 & 10 & 5 & 4 & 0 & 20 & $\begin{array}{rr}1 x-5 & 6 x-2 \\
2 x-5 & 8 x-1 \\
3 x-3 & 15 x-1 \\
4 x-2 & \\
5 x-1 & \end{array}$ & 72 & $0.3 \%$ \\
\hline $\begin{array}{l}\text { Five } \\
\text { Year } \\
\text { Total }\end{array}$ & $: 1$ & 14 & $u$ & 4 & 4 & 01 & 7 & 17 & $u$ & 1118 & $\begin{array}{rr}1 x-44 & 6 x-2 \\
2 x-30 & 8 x-1 \\
3 x-15 & 10 x-4 \\
4 x-8 & 15 x-1 \\
5 x-2 & 100 x-1\end{array}$ & 366 & U. $33 \%$ \\
\hline $\begin{array}{l}\text { \% of } \\
\text { Total } \\
\text { Sample } \\
\text { Jaken } \\
\text { In Area }\end{array}$ & $0.02 \%$ & $0.01 \%$ & $0 \%$ & $0.04 \%$ & $0.07 \%$ & $0.4 \%$ & $0.08_{a}^{\sigma}$ & $0.2^{\mathrm{a}}=$ & 0 & $0.11 \%$ & & & \\
\hline
\end{tabular}

Both Tables 2-12 and 2-13 provide evidence that the air quality within the laboratories steadily improved over the four-year period 1976 through 1979. However, during 1980 the number of investigative air samples increased somewhat. The figure-of-merit value given in Table 2-13 in terms of equivalent number of sample days at MPC declined by a factor of 13 from 1976 to 1979 but increased by a factor of four from 1979 to 1980, although the figure-of-merit for 1980 was still very low and consistent with 1977 and 1978 levels and the five-year average (1976-1981). The recent increase (relative 
to 1979) is due to the increased number of high air samples in the analytical laboratory and the ARD laboratory in the Plutonium Fuels Development Laboratories (Building 8) which occurred as a result of decontamination activities involved in removing and disposing of glove boxes in the ARD laboratory and to the fact that there was little activity involving nuclear fuel in the NFD portions of the facilities during 1979.

\subsubsection{PERSONNEL EXPOSURE ESTIMATES}

The data provided in Tables $2-12$ and 2-13 by themselves are not sufficient to make an estimate of personne 1 exposure. Since the majority of the room air samples measured fall below the MDA, the estimate for exposure during 1980 must be based on the assumption that all samples $\leq$ MDA were at the MDA concentration. Of all these samples, $40 \%$ are for soluble plutonium with the MDA at 5.5\%; and the remaining $60 \%$ are for insoluble plutonium with the MDA at $0.3 \%$ of MPC. The weighted average for the increment of samples which are $\angle M D A$ would provide an average exposure estimate of $2.4 \%$ if MPC.

Added to this increment would be those samples between the action level and MPC. For 1980, this adds about $0.1 \%$ of MPC. An additional increment is the samples which are greater than MPC. Using the figure-of-merit data in Table $2-13$ for the 1980 average adds $0.3 \%$ of MPC. There would also be an increment of dose for air samples which fall between the MDA and the action level which has not been taken into account. Only a very small number of samples fall into this group, probably of the same order of magnitude as the number of samples greater than MPC. The total for these dose increments is thus approximately $3 \%$ of MPC for 1980. This value compares with $4.6 \%$ for 1979 and $6 \%$ of MPC for the average of the four previous years. This represents a maximum exposure estimate since $80 \%$ of the estimate is based on the assumption that all air samples that are less than the MDA concentration are taken as being at the MDA concentration. Thus, although the number of air samples > MPC increases about a factor of 2 in 1980 compared with 1979, the effective figure of merit (indicative of internal exposure) was evaluated to be a factor of 2 lower than the previous four years. This is probably not an actual improvement but only an indication of being able to more accurately assess actual conditions at the lower exposure levels. Thus the small incremental increase in exposures above MPC is well within the overall uncertainty of total exposure from inhalation of airborne contamination. 


\subsubsection{STACK EFFLUENT DISCHARGES AND EXPOSURE OF OFF-SITE INDIVIDUALS}

Concentration levels of gross alpha activity in stack effluents $\left(C_{S}\right)$ are based on samples collected for one-week periods. The recorded measurements for the Cheswick Laboratories during the last 6-1/2 years (1975 through mid 1981) show that the annual average concentrations in stack effluents in most cases do not exceed the MDA levels of the samples. In no case did the samples show activities that exceeded the maximum permissible concentrations for unrestricted areas. The counting system has an MDA level of $3.3 \times 10-15^{-15}$ $\mathrm{\mu C} \mathrm{i} / \mathrm{CC}$ for the weekly stack samples, which is equivalent to $5.5 \%$ of MPC. The annual average for all stacks in Buildings 7 and 8 were taken as equal to the counting MDA value. This is based on the fact that those samples that showed activities $>M D A$ are a small fraction of the total sample and are considered to be insignificant.

Based on these conditions, the maximum dose rate increments to an off-site individual as a result of inhalation of plutonium discharged from the Building 8 were calculated as $0.01 \mathrm{mrem} /$ year to the lung if the plutonium were all in an insoluble form and $0.04 \mathrm{mrem} /$ year to the bone if the plutonium were all in a soluble form. Comparable increments at the same location as a result of Building 7 plutonium laboratory releases were calculated as $0.002 \mathrm{mrem} / \mathrm{year}$ to the lung and $0.006 \mathrm{mrem} /$ year to the bone for $100 \%$ insoluble or $100 \%$ soluble forms of plutonium, respectively. Based on the conditions defined above, the total airborne discharge of plutonium alpha activity averaged $0.8 \mathrm{\mu C} /$ year or less from Building 8 and $0.09 \mu \mathrm{Ci} /$ year or less from the plutonium laboratory in Building 7 . These relatively low values are, most likely, a large overestimate of actual conditions since analysis of stack samples performed in 1975 showed that plutonium activity was only about four percent of the total alpha activity; and in the present analysis, all activity is assumed to be discharged at the minimum detectable level of total alpha activity.

The total dose increment to the lung from all SNM-1120 plutonium operations, assuming that all effluents are in the insoluble form, was calculated to be $0.012 \mathrm{mrem} /$ year. This amounts to only $0.048 \%$ of the Environmental Protection 
Agency (EPA) standard and $0.0008 \%$ of the NRC standards. The total dose increment to the bone, assuming that all plutonium effluents are in the soluble form, was calculated to be $0.046 \mathrm{mrem} / \mathrm{year}$. This amounts to only

$0.18 \%$ of the EPA standard and $0.002 \%$ of the NRC standards for the off-site environment. 


\subsection{PROJECT COST AND SCHEDULE}

\subsection{BACKGROUND}

Estimates of cost and schedule to complete the D\&D of the westinghouse ARD Fuel Laboratories at Cheswick were initiated with the receipt of DOE/CH letter H. N. Miller to J. V. Yerace, ARD dated August 16, 1978, subject, "Westinghouse ARD Fabrication Facility," requesting such estimates. In the time period August 16, 1978 to July, 1980, considerable effort was applied to assessing options for deactivating these fuel laboratories, preparing cost and schedule estimates for the various options, and interfacing and discussing with $\mathrm{DOE} / \mathrm{CH}$ personnel these estimates in relation to corresponding estimates independently prepared by $\mathrm{DOE} / \mathrm{CH}$ personnel.

Continued discussions between westinghouse and the customer led to a narrowing of differences on the cost and schedule aspects resulting in the initiation of formal contract negotiations.

The follow-on negotiations culminated in the submittal by westinghouse of a cost and schedule estimate on July 11, 1980 letter CM-80-867, W. R. Hull to T. $R$. Katisch which represented fairly all the cost and schedule agreements reached between both parties as of that date. Further discussions led to minor modifications of the July 11 submittal and were documented in follow-on Westinghouse letters, specifically CM-80-881, dated July 15, and CM-80-917, dated July 21,1980 . The outcome of the above negotiations formed the final cost and schedule estimates which were carried forward to the "Definitive Supplemental Agreement to Contract No. DE-AC02-80ET37247 between Westinghouse Electric Corporation and the U. S. Department of Energy." 


\subsection{INITIAL COST}

The total estimated cost for the performance of work in Phases $1-4(1,2)$ is $\$ 4,031,745.00$. The breakdown by phases is as follows:

Phase 1 (Planning)

Phase 2 (D\&D Operations)

Phase 3 (Packaging, Shipping and Burial)

Phase 4 (Final Cleanup, Third Party Survey)
$\$ 879,096^{(3)}$

$\$ 1,790,894$

$\$ 1,083,658^{(4)}$

$\frac{\$ 278,097}{\$ 4,031,745}$

(1) To be defined in subsequent paragraphs on schedule.

(2) There is also a Phase 5 as part of this contract; it also will be defined further under schedule, but it will not be a part of this final report.

(3) $\$ 991,241$ in letter CM-80-867 but modified to $\$ 879,096$ by 1etter CM-80-881.

(4) $\$ 1,034,233$ in Letter CM-80-867 but modified to $\$ 1,127,633$ in Letter CM-80-917 and further modified to $\$ 1,083,658$ in final discussions between Westinghouse ARD and $\mathrm{CH}$ Contracts personne?. 


\subsection{INITIAL SCHEDULE}

In parallel to the preparation and negotiation of cost, considerable effort was spent on the preparation of a D\&D plan (Attachment 1) that encompassed the scope of work to be performed, the method for performing the work, and the schedule.

The scope of work defined in the plan included the complete D\&D of the Westinghouse ARD Fuel Laboratories at Cheswick in the shortest possible time--estinated at two to three years.

It is divided into four phases ${ }^{(5)}$ as described previously in section 2.1 .

It is to be clarified at this point that the method selected for handling/disposing of one of the main items of equipment, the glove boxes, was the "volume reduction" technique in which the glove boxes would be dismantled and cut apart into sections of size that would be accepted by the M-III steel bin for ultimate burial. It was this method that was used as the basis for the cost estimate presented in the previous section, and it also was the method considered in Revision 2 of the $0 \& D$ plan, which formed a part of the definitive contract.

$(5)$ As noted previously, while phase 5 was part of the contract covering this $D$ and $D$ effort, it was being carried out separately from phases 1 through 4, and was not included in this report. 
Schedular information consistent with Revision 2 of the D\&D plan and also with the initial cost estimate is shown in Figure $3-1$. Figure $3-2$ contains a detailed schedule for Phases 1 through 4 . In essence, the ARD estimate of time to complete this job was 29 months, starting July, 1979, and finishing December 31, 1981.

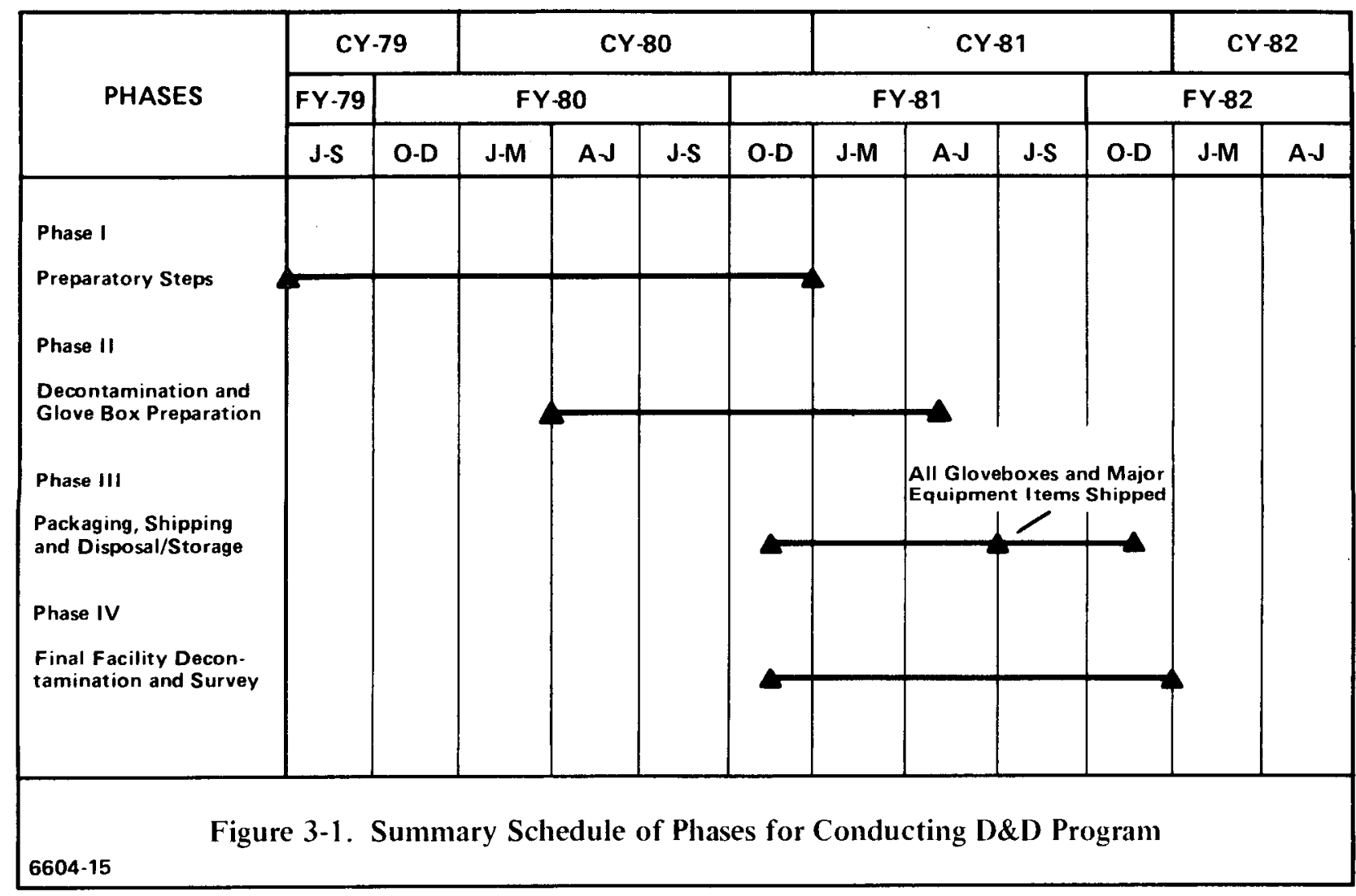




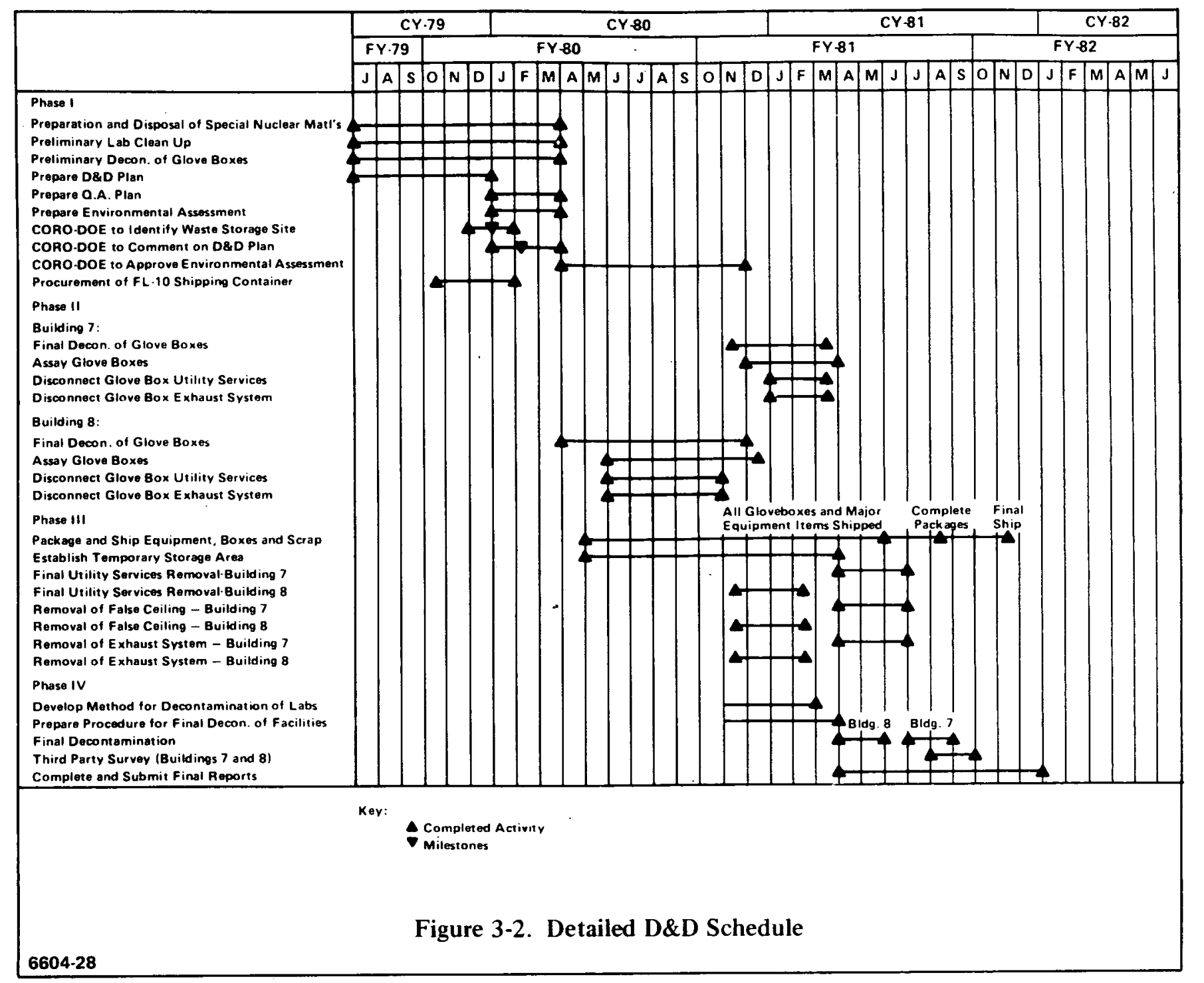




\subsection{MODIFICATIONS TO SCOPE OF WORK AND SCHEDULE}

As might be expected with a "first-of-a-kind" project, a number of modifications to the scope of work developed as a result of both internal and external factors. The more important factors are:

A. Change in method for handling/disposing of the glove boxes from "volume reduction". to "whole box." The important aspects included elimination of the labor-intensive operation of cutting apart the glove boxes into smaller sections capable of being packaged in the $M-I I I$ steel bin, and design and fabrication of the FRP boxes into which the whole glove boxes were loaded for shipping and burial.

B. Acceleration of schedule to make up for delays caused by redesign of the FRP required by $\mathrm{RHO}$, and withdrawal by NRC of all Super Tiger shipping container Certificates of Compliance.

C. Acceleration of schedule associated with completion of all waste shipments to the burial site at Hanford, Washington, prior to July 1 , 1981, to circumvent potential problems created by the adoption of Initiative Measure 383 by the voters of the State of Washington. Reference is made to ARD letter CM-81-152, dated January 30, 1981, $W$. R. Hull to DOE/CH (E. R. Speizman).

The above modifications led to the preparation of Revision 3 of the D\&D p Ian, which was transmitted to DOE/CH February 15, 1981 via ARD letter CM-81-170. This revised plan contained both the scope of work and schedule modifications. With respect to schedule, the significant change was in Phase 3 (packaging, shipping and disposal of waste) in which the completion date was accelerated from December 31, 1981 to June 30, 1981. Overal1 project completion date remained unchanged at December 31, 1981. 


\subsection{FINAL ESTIMATED COST AND SCHEDULE}

The final cost for Phases 1 through 4 of the $D \& D$ of these fuel laboratories is estimated at $\$ 3,951,674$.* The breakdown of these costs is presented in Table $3-1$.

TABLE 3-1

BREAKDOINN OF COSTS COVERING D\&D OF THE ARD FUEL LABORATORIES AT-CHES!UICK

\begin{tabular}{|c|c|c|c|c|c|}
\hline & Labor & $\begin{array}{c}\text { Haterial and } \\
\text { Services }\end{array}$ & $\begin{array}{c}\text { Major } \\
\text { Subcontracts }\end{array}$ & $\begin{array}{l}\text { Interworks } \\
\text { Requisitions }\end{array}$ & Total \\
\hline Phase 1 & 651,122 & 10,236 & - & 233,436 & 884,794 \\
\hline Phase 2 & 303,975 & $\begin{array}{r}333,276 \\
467(a)\end{array}$ & 8,402 & 753,176 & $\begin{array}{r}1,898,829 \\
467(a)\end{array}$ \\
\hline Phase 3 & 247,355 & $\begin{array}{l}7,451 \\
3,816\end{array}(a)$ & $\begin{array}{l}351,807 \\
182,414\end{array}$ & 230,514 & $\begin{array}{l}837,129 \\
186,230^{(a)}\end{array}$ \\
\hline \multirow[t]{2}{*}{ Phase 4} & 54,977 & 2,941 & $\begin{array}{l}28,635 \\
7,672\end{array}$ & 50,000 & $\begin{array}{r}136,553 \\
7,672\end{array}$ \\
\hline & $1,757,429$ & 358,187 & 578,932 & $1,257,126$ & $3,951,674$ \\
\hline (a) & nated Cost & Open Orders & & & \\
\hline
\end{tabular}

The schedule presented in Revision 3 of the D\&D plan was met. One of the major accomplishments with respect to schedule was meeting the June 30, 1981 date for shipping all glove boxes and major equipment items. To accomplish this, ARD had under contract for the months of February, March, April, and May, 1981, three "Super Tigers" and one "Poly Panther," which maintained steady state transfer of the generated packaged waste from the Cheswick Site to the Hanford burial site. All in all, 31 shipments (21 "Super Tiger" and 10 "Poly Panther") were made without incident.

* Final invoices have not been received for services provided by external contractors, thus this cost figure must be considered as an estimate at this writing $(2 / 82)$. 
A11 D\&D activities of the laboratories were completed by September 1981. ANL conducted the independent radiation survey September 29 to October 8, 1981.

$A R D$ has not been presented as yet with the final results of this survey as analyses continue at ANL. When these results are made available, they will be included as an addendum to this report. 


\subsection{FINAL SITE CONDITION}

\section{1 CRITERIA}

The objective of this D\&D program was to dismantle the fuel laboratories to the extent that the resulting facilities might be utilized without reconstruction or reservation for any other purpose. The criteria pertaining to residual level of contamination for meeting this objective are contained in standard ANSI N13.12 (draft) and facility operating license SNM-1120 Annex C. The following section details the requirements of these documents and the final levels of contamination reached in satisfying these requirements.

\subsection{FINAL CONDITION}

\subsubsection{GENERAL DESCRIPTION OF METHOOS}

Radiation surveys of the plutonium laboratory room surfaces were performed in several steps based on operating procedures prepared specifically for these surveys. The first procedure (PDL-0P-D-0835) covered the methods used to establish a grid system to uniquely identify areas of the walls, floor, and ceiling to be surveyed. A second procedure (PFDL-0P-D-0841) was written for performing a preliminary survey of the plutonium laboratory room surfaces in Building 8. The purpose of this procedure was to establish location of areas of excessive radiation contamination ("hot spots") and to ensure that these areas were cleaned and deconned prior to removing paint from the walls and floor. This preliminary survey procedure involved a total (100 percent) survey of the room surface areas with a PAC-4G alpha detector and measurement of removable contamination wherever excessive activity (as determined by the $P A C-4 G$ ) was found to occur. For the Building 7 plutonium laboratory, such a thorough preliminary survey was not deemed necessary since there was no history of any major incidents resulting in extensive contamination. Therefore, only a total survey of the floor area with spot checks of the walls and ceiling was carried out. 
Another procedure (PFDL-OP-D-0842) describes the requirements of monitoring radioactive contamination in holes or penetrations within the walls, floor, or ceiling. Finally, a procedure (PFDL-OP-D-0834) was also written for performing the final survey of wall, ceiling, and floor surfaces. This procedure requires that a 11 surfaces meet the limits of contamination for uncontrolled use according to American National Standards Institute (ANSI) N13.12 and License SNM-1120 decommissioning criteria and uses a statistical sampling approach to ensure that these criteria are met. The detailed procedures used in the plutonium laboratory radiation surveys are listed in Appendix B.

Miscellaneous surfaces not covered by the above procedures (that is, ducting, piping, trusses) were surveyed for removable contamination by smears. These data were recorded on miscellaneous smear data sheet records with attached sketches of survey locations. Gamma dose rates were determined by performing a preliminary survey with a gamma survey meter (that is, E-120 with HP-190 probe) to establish non-interference from adjacent rooms and by taping environmental TLD packets near the center of each grid area selected for the final survey (according to Procedure PFDL-OP-D-0834) for a fixed period of time (one month).

Personnel performing or assisting in these surveys were instructed in the procedures and were authorized as qualified by a sign-off sheet acknowledging the individuals' understanding and ability to perform the procedure as approved by the Supervisor of Industrial Hygiene.

Details of the survey results follow. 


\subsubsection{DETAILED RESULTS OF BUILDING 8 SURVEYS}

During the preliminary survey of the ARD plutonium laboratory in Building 8, 28 grids ( 1 meter $\times 1$ meter area) out of the 216 total on the floor showed excess contamination (that is, $>300 \mathrm{dpm} / 100 \mathrm{~cm}^{2}$ fixed and/or $>20 \mathrm{dpm} / 100$ $\mathrm{cm}^{2}$ removable of alpha activity)* above the unrestricted limits for unqualified release. Locations of these "hot spots" on the floor are shown schematically in Figure 4-1. After proper deconning procedures were used, all contaminated areas met the unrestricted limits as given above, except for two small areas on the floor which were carefully marked.

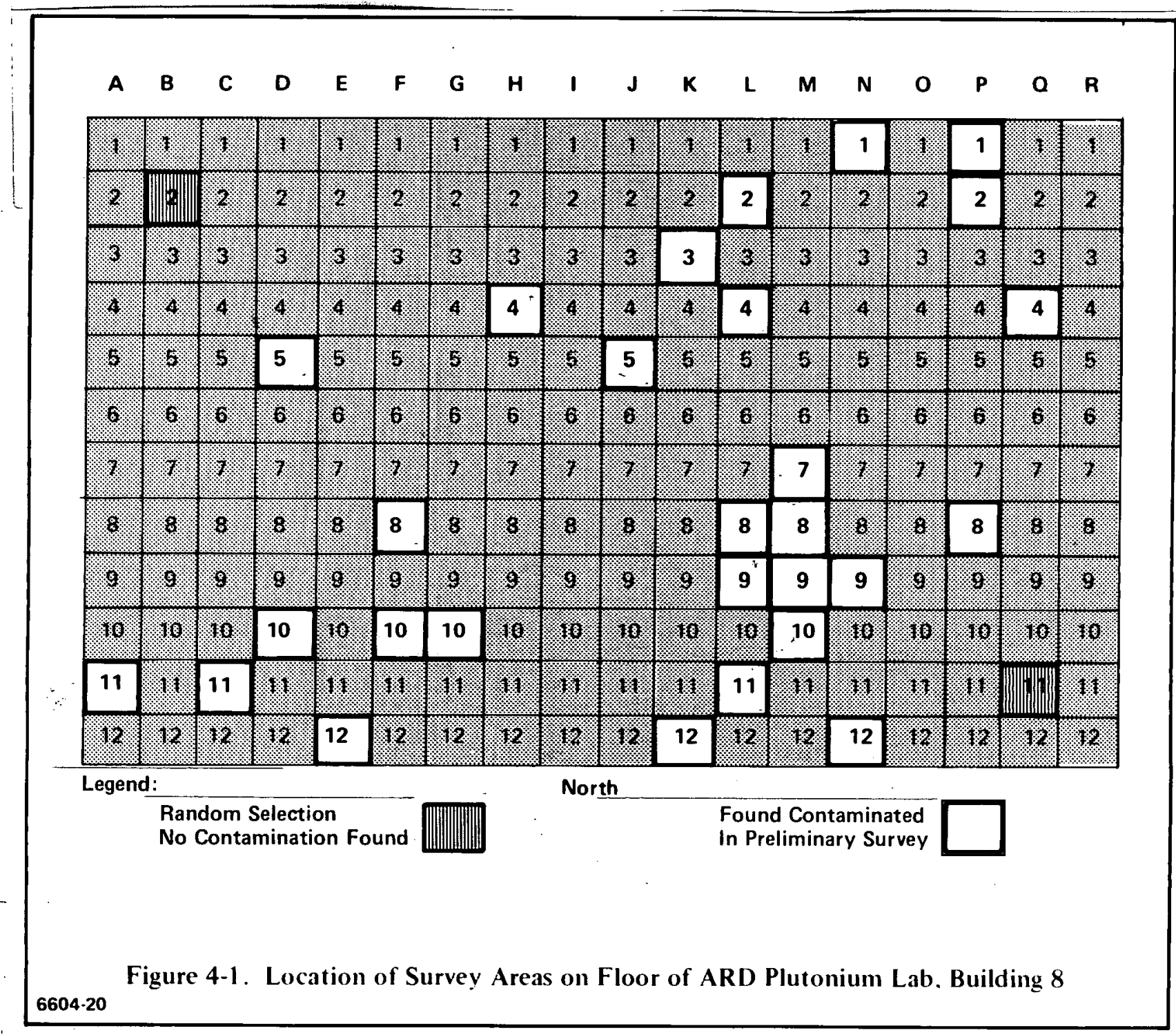

*Note that $s$ activity levels of $15,000 \mathrm{dpm} / \mathrm{cm}^{2}$ and $1000 \mathrm{dpm} / 100 \mathrm{~cm}^{2}$ for total and removable activity levels also exist. Preliminary surveys, however, of the $\beta / \alpha$ ratio on the laboratory surfaces in Buildings 7 and 8 showed a maximum of 5 to 1 while the largest theoretical ratio for any fuel processed was 34 to 1 . Since these are less than the 50 to 1 ratio of 8 to a limits, a complete survey of 8 contamination was not deemed necessary. 
unrestricted limits. On the west wall (Figure 4-3), seven grid areas were

below the unrestricted limits.

\begin{tabular}{|c|c|c|c|c|c|c|c|c|c|c|c|c|c|c|c|c|c|}
\hline A & B & C & D & E & $\mathbf{F}$ & G & H & I & J & K & $L$ & $\mathbf{M}$ & $\mathbf{N}$ & 0 & P & $\mathbf{Q}$ & $\mathbf{R}$ \\
\hline 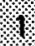 & 1 & 8 & 样 & 誉 & 1 & 1 & 钐 & & / & II & 啋 & fif & . & Ko & 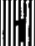 & 相 & 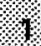 \\
\hline \% & \% & 2 & 2 & \% & 2 & 2 & $\%$ & 2 & 㴗 & 巽 & 2 & 䍃 & $\%$ & 涪 & 2 & 1 & 20 \\
\hline . & 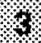 & \% & 3 & 梦 & 3 & 3 & 3 & i. & 6 & (xis & 等 & 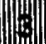 & 3 & : & 3 & \multirow{2}{*}{\multicolumn{2}{|c|}{18041}} \\
\hline 4 & 4 & 4 & \%. & 4 & $\%$ & 4. & in. & 4 & 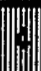 & 4 & 4 & 4 & (4) & 4 & 4 & & \\
\hline
\end{tabular}

Legend: Random Selection

No Contamination Found

Found Contaminated

In Preliminary Survey

Figure 4-2. Location of Survey Areas on North Wall of ARD Plutonium Lab, Building 8 $6604-21$

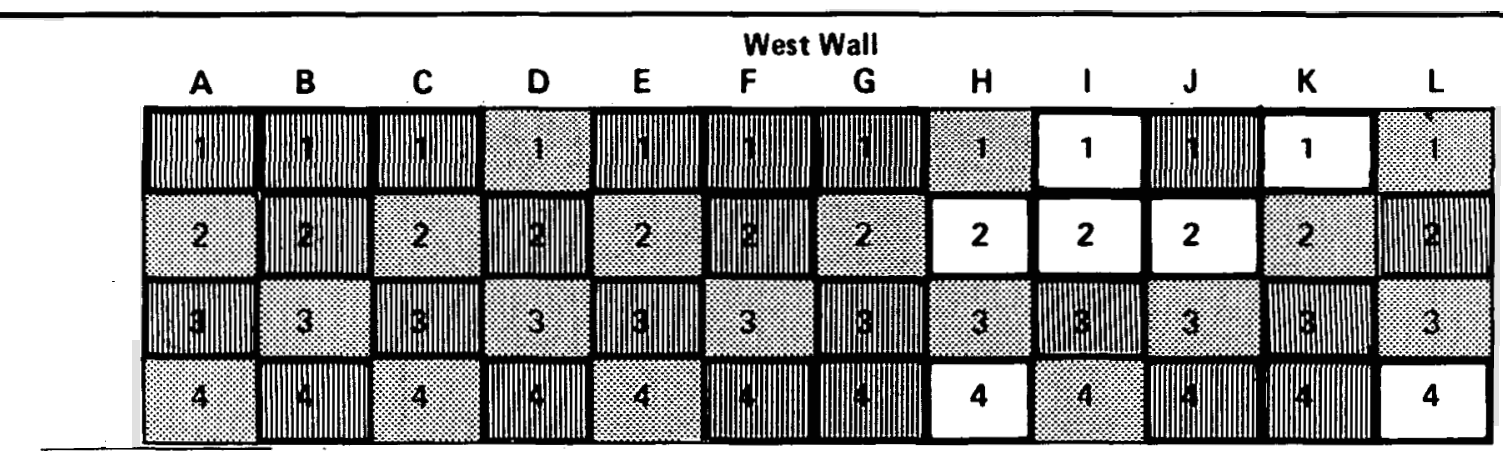

Legend:

Random Selection

No Contamination Found

Found Contaminated

I In Preliminary Survey

Figure 4-3. Location of Survey Areas on West Wall of ARD Plutonium Lab, Building 8 
On the ceiling (Figure 4-4), three grid areas were found to have spots with excess contamination and these were also cleaned to below the unrestricted limits. The south wall and east wall areas (Figure 4-5) were not found to have any spots with contamination that exceeded the unrestricted limits.

\begin{tabular}{|c|c|c|c|c|c|c|c|c|c|c|c|c|c|c|c|c|c|}
\hline A & B & C & D & $\mathbf{E}$ & $\mathbf{F}$ & G & H & 1 & J & K & $\mathbf{L}$ & $M$ & $\mathbf{N}$ & 0 & $\mathbf{P}$ & 0 & $\mathbf{R}$ \\
\hline 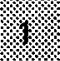 & (3) & 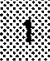 & (2) & / & i) & 楼 & th & 楼. & (I) & ) & 约 & 1 & \% & 1 & $1 \%$ & 4 & 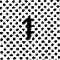 \\
\hline . & $(2$ & 2 & 2 & 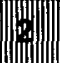 & \% & 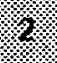 & men & 8 & 衫 & 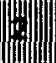 & ? & 2 & 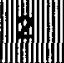 & \% & 2. & 2 & 2. \\
\hline , & 4. & 3 & 3 & 3 & 3 & * & (3) & 3 & \% & 3 & 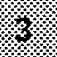 & 䋇 & \% & 3 & 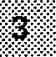 & 3 & (3) \\
\hline \% & 4. & . & 4 & 潾 & 4 & 4 & 4. & 4 & 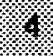 & 4 & $\sqrt{4}$ & 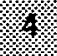 & 4 & \% & 4 & 4. & 4 \\
\hline 6 & 5 & 5 & 5 & 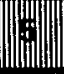 & 泾 & 9. & $a^{2}$ & 9. & 45 & 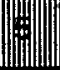 & א. & \% & 部 & 5 & $\sqrt{8}$ & 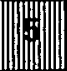 & 3. \\
\hline$\sqrt{x}$ & 4. & 16. & 64 & 60 & 6. & 6. & 6 & 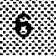 & \% & (6) & 约 & 6 & 6. & 6 & 6 & (8). & 6. \\
\hline : & \% & $1 \%$ & \% & \% & \% & II & (1) & (3) & ? & $\sqrt{3}$ & it: & 将 & \% & צ. & ? & (1) & $1 \%$ \\
\hline$\%$ & (5) & 6 & 8 & -4 & 8 & 18 & 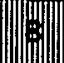 & 8 & K & 8 & 8 & 8 & $\| 4$ & (3) & 6 & 8 & 3. \\
\hline 4 & (9) & 49 & (9. & \% & 9 & 8 & \% & 9 & q & 6. & 9.9 & 9. & 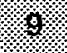 & 10 & 4 & 4 & 4 \\
\hline 4 & 10 & 10 & 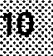 & 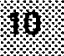 & \% & 16 & 10 & 18. & (6) & 18 & $x^{\prime 3}$ & 318 & 19 & 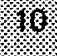 & 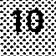 & 10 & 17 \\
\hline \% & , & 4 & 11 & 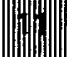 & rit. & 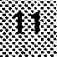 & 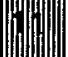 & 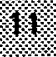 & 4 & 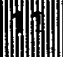 & / & 13 & $m$ & 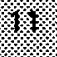 & I & m & $1 /$ \\
\hline$\sqrt{1}$ & $1 \%$ & 12 & 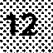 & W & 12 & 12 & 1 & 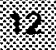 & 12 & 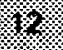 & 12 & 4 & $1 / 2$ & 42 & 16 & 18 & 18 \\
\hline 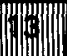 & 13 & 18 & 14 & 4 & (3) & $f$ & / & (6) & 18 & (18) & 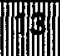 & 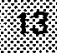 & 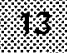 & (1) & 18 & $\sqrt{13}$ & 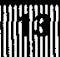 \\
\hline
\end{tabular}

Figure 4-4. Location of Survey Areas on Ceiling of ARD Plutonium Lab, Building 8 6604-23

In addition to surveying the surfaces of the plutonium laboratory area, holes and penetrations of the wall also were surveyed for residual contamination, although it seemed unlikely that any significant quantity of plutonium activity was contained in these wall penetrations. The room has a slightly negative pressure relative to the area between the walls and the outside atmosphere and thus air which flowed through such penetrations was directed inward towards the room and most penetrations were filled with plugs, pipes, etc. For the type of isotopic plutonium mixture handled in the ARD plutonium 
1 aboratories, the ratio of $\beta$ to $\alpha$ particles emitted per disintegration was at least seven to one. Therefore, the sensitivity to detect plutonium (assuming a predominance of plutonium activity relative to other completing s emitters) is enhanced by measuring $\beta$ rather than a activity.

A thin end window $\left(<2 \mathrm{mg} / \mathrm{cm}^{2}\right.$ ) HP-190 GM tube probe was connected to a Rascal detector with digital readout. This instrument was calibrated by a combination of Pu-239, Am-241, and Th-230 sources to provide an overall efficiency of 22 percent for $P U B-\gamma$ activity.

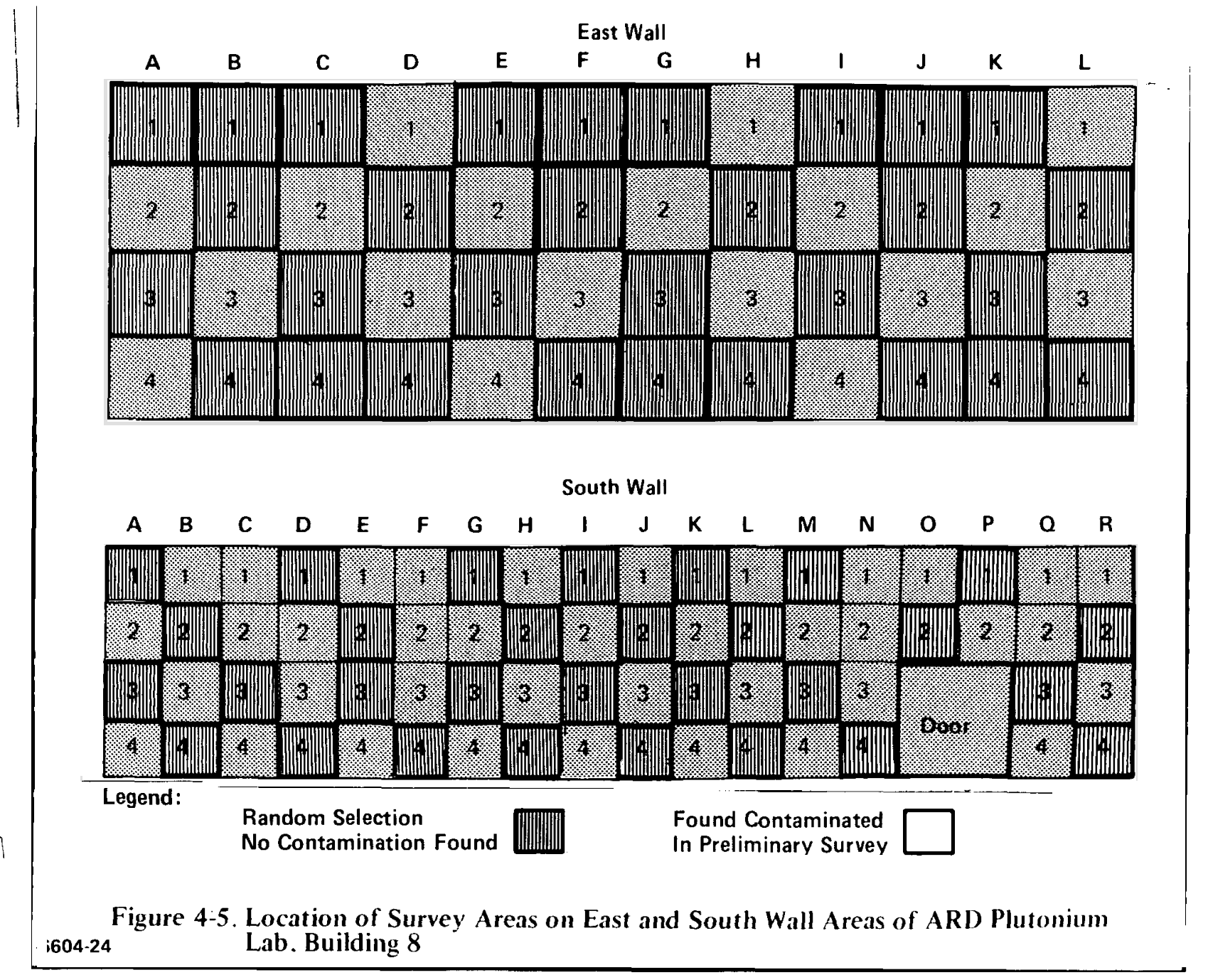


An acceptable level for fixed contamination of each hole was chosen on the basis of the unrestricted surface contamination limits as noted above $<<300$ $\mathrm{dpm} / 100 \mathrm{~cm}^{2}$ ) and the detectability limits of the detector system. Detectability limits for the HP-190 and Rascal range from 19 to 23 counts per minute (cpm) for background counting rates of 60-95 cpm. Based on a measured efficiency for plutonium bs of 22 percent, the MDA ranges from 86 to $102 \mathrm{dpm}$ of equivalent activity. For a four-inch diameter hole, the maximum unrestricted contamination limit of $300 \mathrm{dpm} / 100 \mathrm{~cm}^{2}$ would result in 250 $d p m$. For smaller holes, the surface contamination per unit area would be higher; but calculations show that due to collimation and source distribution effects, the detected leakage would be about the same. Since $250 \mathrm{dpm}$ is well above the MDA of about $100 \mathrm{dpm}$, it should be easily detected. Thus, a limit of $250 \mathrm{dpm}(20.1 \mathrm{nCi})$ was assigned to each hole for fixed contamination. This technique proved to be very satisfactory in detecting contaminated hole surfaces provided that interference from high gamma background from adjacent $1 \mathrm{ab}$ areas was not present. However, the initial $\beta-\gamma$ probe hole survey on the north wall of the ARD plutonium laboratory did encounter excessive background due to materials and gross contamination in and on hoods in the adjacent room on the other side of this wall (analytical lab area). Hence, another technique had to be used for the areas where such high background interference occurred. To eliminate the $8-\gamma$ background, a $P A C-4 G$ alpha detector was employed. To minimize extraneous background on this detector, cardboard "shields" with various size holes were used to reduce any wall contamination effect on the detector to a minimum. Furthermore, the detector surface was cleaned and deconned to the maximum extent possible such that the intrinsic background of the instrument per se was $<25 \mathrm{cpm}$. By this method, the lower limit of detection or MDA was reduced to about $25 \mathrm{cpm}$ (or twice background). Since the alpha efficiency for collimated sources of this type was 11 percent, the minimum detectable activity was $230 \mathrm{dpm}$, or slightly less than the assigned limit of $250 \mathrm{dpm}$. Although the margin between minimum detectable activity and the assigned limit (230 versus 250) was inuch smaller in this case than it was for the thin end window $b-\gamma$ measurement, levels in excess of the unrestricted limit were still detectable. 
Also, for all holes equal to or larger than an equivalent circular diameter of 0.5 inches, removable contamination was measured by taking a smear on the inside surface of the hole. The low background of the smear counters $(<1$ cpm) coupled with a longer ( 5 minutes) count easily permit the required sensitivity of $\leq 20 \mathrm{dpm} / 100 \mathrm{~cm}^{2}$ to be achieved.*

The survey of total (fixed plus removable) activity in the holes showed no holes with activity exceeding the acceptance criteria for $250 \mathrm{dpm}$ for the west wall, east wall, south wall, or ceiling surfaces. Twenty-three holes were initially identified as not meeting the acceptance criteria in the north wall, but it is believed that most (if not all) of these holes were found to exceed the acceptance criteria because of the background interference coming from the adjacent room (analytical laboratory). Initially, six holes indicated contamination beyond the limits set based on the $\beta-\gamma$ type survey indicated above; and when it was determined that a high background from the adjacent room was most likely causing these high readings, the survey procedure in this area was modified to use a collimated, low background alpha detector and 17 additional holes with excessive contamination were identified by this measurement technique. It is believed that most of these measurements were found to exceed the criteria because of the small margin of difference between the MDA and the acceptable level. However, the holes were cleaned and measurements were repeated until the measured value was below the acceptable criteria of $<250 \mathrm{dpm}$.

The removable activity was also sampled on the inside hole surface for all holes equal to or greater than 0.5 inches in equivalent diameter. This procedure proved to be a more sensitive measure of contamination than the measurements of total contamination. Based on these measurements, 16 holes in the west wall, 11 holes each in the respective east and north walls, and seven holes in the south wall were initially found to exceed the acceptability limits of $<20 \mathrm{dpm} / 100 \mathrm{~cm}^{2}$. All of these holes were cleaned and deconned to below the acceptability limits. These holes were then sealed with duct tape prior to removing paint from the walls.

*MDA for the lowest efficiency counter (36\%) with highest permissible background $(1 \mathrm{cpm})$ is $13.9 \mathrm{dpm} / 100 \mathrm{~cm}^{2}$ for the smallest hole $(0.5$ inch diameter). 
For the final survey of inner laboratory surfaces (walls, floor, and ceiling) after paint had been removed from the plastered walls and paint and the surface layer of epoxy had been removed from the floor, a statistical approach was employed. Based on a random selection of grids, only a small portion of the total area was surveyed. The procedure requires an initial selection of 30 grid areas on each of the six major room surfaces. Thus, for the smaller room surfaces (east and west walls) approximately two-thirds of the wall area was surveyed while for the larger room surfaces (ceiling and floor) only about one-eighth of the total room surface was surveyed. In order to bias this survey towards the selection of maximum contamination areas, all of the areas that were previously found to contain contamination were selected as first choice and any additional grids required to make up the selected limit of 30 were chosen at random in a checkerboard pattern. Grids selected for the final survey are shown in Figures 4-1 through 4-5. Within each one meter by one meter grid area, five $20 \mathrm{~cm}$ by $20 \mathrm{~cm}$ areas were marked (see Figure 4-6) for monitoring removable activity by smear counting. Finally, one packet of TLDs was mounted at the top of and adjacent to the centermost sinear area in each of the selected grid areas. These TLDs were taped in place and were exposed for a period of one month, and then they were removed and shipped to a vendor for readout.

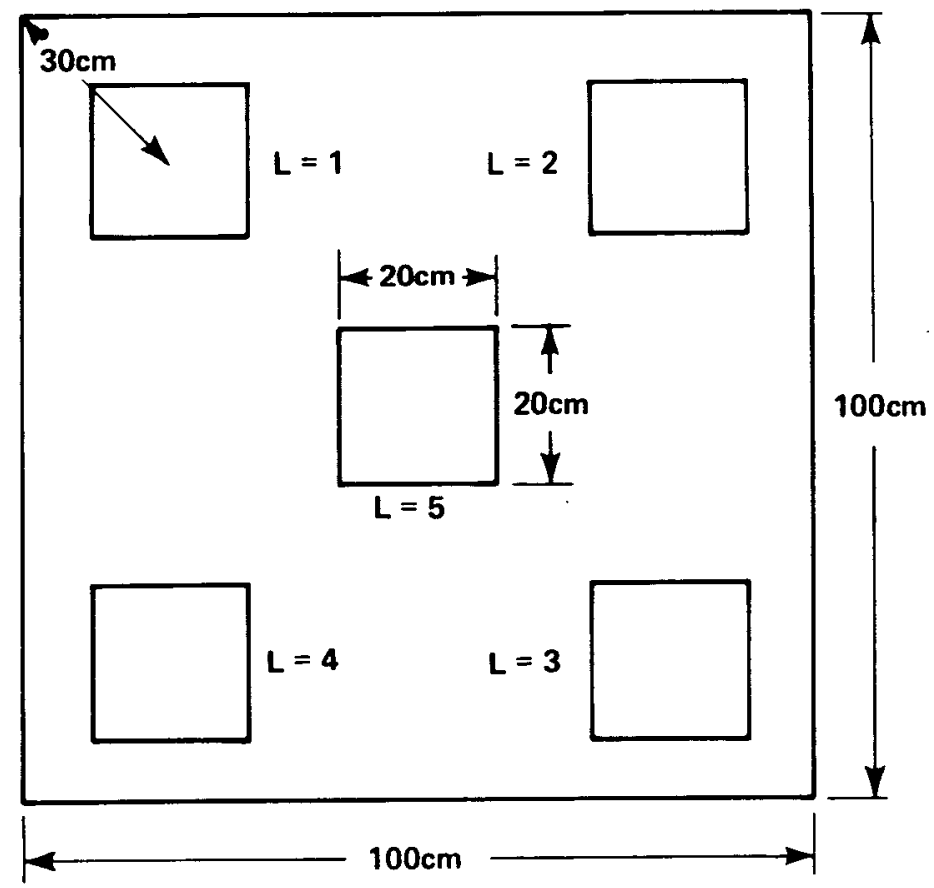

Figure 4-6. Locations for Determining Removable $\alpha$ Activity Within a 1 -Square-Meter Grid 
Following completion of the monitoring of all selected grids in each surface area (wall, ceiling, or floor), a statistical evaluation was performed to determine whether or not the criteria had been met for having a sufficient sample to meet the $90 \%$ confidence limits within the assigned uncertainty of. \pm 25 percent. The number of grids required to meet the assigned statistical values is given by the formula:

$$
n \geq 45 s^{2} / x^{2}
$$

where:

$$
\bar{x}=\text { the sample mean } \sum_{i=1}^{30} x_{i} / 30
$$

and $S^{2}=$ the estimate of sample variance

$$
=\sum_{i=1}^{30}\left(x_{i}-\bar{x}\right)^{2} / 29
$$

If $n$ comes out to less than 30 by this formula, then 30 was a sufficient number. For all six areas monitored at the Building 8 Laboratory, an $n$ of 30 was sufficient. In fact, the floor was the only surface where portions of a grid exceeded average and maximum contamination limits. All grids on the floor showed an average of $\leq 100 \mathrm{dpm} / 100 \mathrm{~cm}^{2}$ except grids $M 12, \mathrm{~K} 12$, and $N$ 10. In grid M 12, one $10 \overline{\mathrm{cm}^{2}}$ area showed a contamination level of 900 $\mathrm{dpm}$. In grid $\mathrm{K} 12$, one $100 \mathrm{~cm}^{2}$ area showed a contamination level of 5,900 dpm; and in grid $N 10$, a $600 \mathrm{~cm}^{2}$ area showed a contamination level of 1,800 $\mathrm{dpm}$ and four other $100 \mathrm{~cm}^{2}$ areas showed levels of $700,900,700$, and $500 \mathrm{dpm}$, respectively. The average $(\bar{x})$ for the whole floor area was thus $103 \mathrm{dpm} / 100$ $\mathrm{cm}^{2}$ and $\mathrm{s}^{2}$ was calculated as 151 . Thus the required value of $\mathrm{n}$ is:

$$
\geq 45 \times 151 \div(103)^{2}=0.64
$$

Since 30 is certainly greater than 0.64 , the sample size was sufficient.

A check was also made to see that we were meeting the $90 \%$ confidence level. This was done by assuring that $\frac{S}{\sqrt{n}} \leq 0.15 \bar{x}$. Using the floor parameters given above, a quick numerical check $(2.24 \leq 15.5)$ assures that this is so. 
The area on the floor in grid $N 10$ where excess contamination was found coincided with the areas that could not be cleaned during the preliminary survey. Apparently the spill of contamination in this area penetrated through the upper surface layers of epoxy coating, either on the original spill or in the process of attempting to clean it up. The other excess contamination areas on the floor (grids $N 12$ and $K 12$ ) were next to the wall opposite the previous location of Glove Box 10 where an incident involving release of plutonium out of the glove box containment occurred in May of 1980 . These contaminated floor areas were subsequently cleaned and the excess contamination was removed so that neither the average nor maximum values for any of the floor areas or any of the other surface areas are exceeded.

None of the wall, floor, or ceiling surface smears exceeded the criteria of 10 $\mathrm{dpm} / 100 \mathrm{~cm}^{2}$. Thus no cleanup of removable activity was necessary and no additional smears had to be taken to satisfy statistical requirements for these measurements. The TLDs which were placed in the selected grid areas for a full month, showed an overall average of $0.011 \mathrm{mr} /$ hour and a maximum of $0.072 \mathrm{mr} /$ hour, well below the decommissioning criteria values for unrestricted use of 0.1 and $0.2 \mathrm{mr} /$ hour, average and maximum, gamma dose rate limits, respectively.

Miscellaneous surface areas (that is, piping, ducting, support structure) were also surveyed. Some 21 locations on miscellaneous surfaces were initially found to be contaminated in excess of the unrestricted limits. These areas were all decontaminated and remeasured to confirm that they meet the unrestricted criteria.

In summary, all the accessible surfaces within the Building 8 plutonium Laboratory area have been surveyed, cleaned as necessary, and resurveyed to show that this entire area meets the License SNM-1120 decommissioning criteria and ANSI 13.12 standard.

\subsubsection{DETAILED RESULTS OF BUILDING 7 SURVEYS}

With the exception of the former darkroom area, the Building 7 ?lutonium Laboratory and peripheral service rooms (lavatory, vault, visitors' entrance, and rear air lock entrance) were initially evaluated in a preliminary survey 
which included a check of all floor areas and spot checks of wall areas with PAC-4G alpha detectors and smears. With the exception of three small areas on the main laboratory floor, all other areas were found to be less than 100 $\mathrm{dpm} / 100 \mathrm{~cm}^{2}$ total contamination and $\leq 20 \mathrm{dpm} / 100 \mathrm{~cm}^{2}$ of removable contamination.

The former darkroom area, which did not have any history of plutonium contamination, was surveyed in a preliminary fashion and was found to have no measurable contamination, fixed or removable. Floor tiles and ceiling panels were removed, and each tile and panel was surveyed to see that it met the unrestricted disposal limits. All of the walls were surveyed and were below detectable limits for fixed and removable contamination. One plasterboard wall was removed, and the doorway and vent area in the wall adjacent to the plutonium laboratory was sealed from the laboratory by cementing concrete blocks in place. Thus this room has been converted to a storage area and has not been included in the final radiation survey of the plutonium laboratory peripheral areas.

Ceiling panels were removed from the main laboratory, and although all panels were surveyed for a contamination, no panels with contamination exceeding disposal limits were found. Although the ceiling panels were sealed in place so that no contamination should have been able to reach the upper wall and inner roof surface areas even if appreciable contamination had been present in this room, a decision was made to spot check this area in the preliminary survey and to perform a detailed check during the final survey. Since this laborabory had no history of any incidents involving significant breach of containment, no further detail on the preliminary survey was deemed necessary.

For the final survey, all wall, floor, and ceiling areas for the main 1 aboratory and peripheral support areas, as noted above, were gridded according to Procedure PFDL-OP-D-0835 with one exception. Since the inner roof area of the main laboratory was corrugated and separated by support stringers located 61.5 inches apart, a rectangular grid pattern of 61.5 inches $(156 \mathrm{~cm})$ by 24 inches $(61.0 \mathrm{~cm})$ and approximately one square meter in area was utilized rather than the specified one meter by one meter grid used elsewhere. Also, smear areas of 10.5 inches $(26.7 \mathrm{~cm})$ by 6.0 inches $(15.2 \mathrm{~cm})$ 
and approximately $400 \mathrm{~cm}^{2}$ in area were selected according to the sketch shown in Figure 4-7 for smear testing for removable contamination. Finally, selection of grid areas to be surveyed in the peripheral support areas was based on the following considerations:

A. All surfaces of the same type (that is, north wall, ceiling, floor) were lumped together and 30 selected grid areas were chosen as a whole for each combined peripheral surface area of the same type. This decision was justified on the basis that: (1) these areas were small relative to the main laboratory and (2) plutonium was not routinely handled in any of these areas. Therefore, plutonium should not be present except by accidental airborne or personnel-borne transport.

B. Since only three small areas on the floor of the plutonium laboratory showed any excess contamination during the preliminary survey, all grids in Building 7 (with the exception of the contaminated areas) were chosen arbitrarily in a random checkerboard pattern. Designation of the grids chosen for the final survey in Building 7 is shown schematically in Figures 4-8 through 4-11.

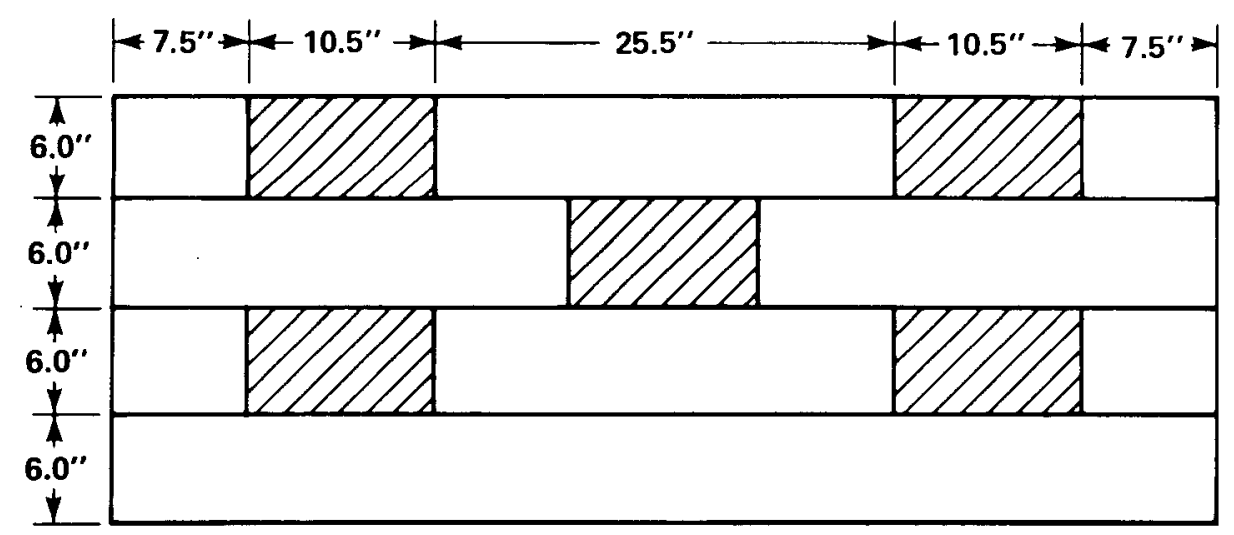

Figure 4-7. Sketch of Roof Area Grid With Designated Smear Locations for Survey in Building 7 Plutonium Lab 


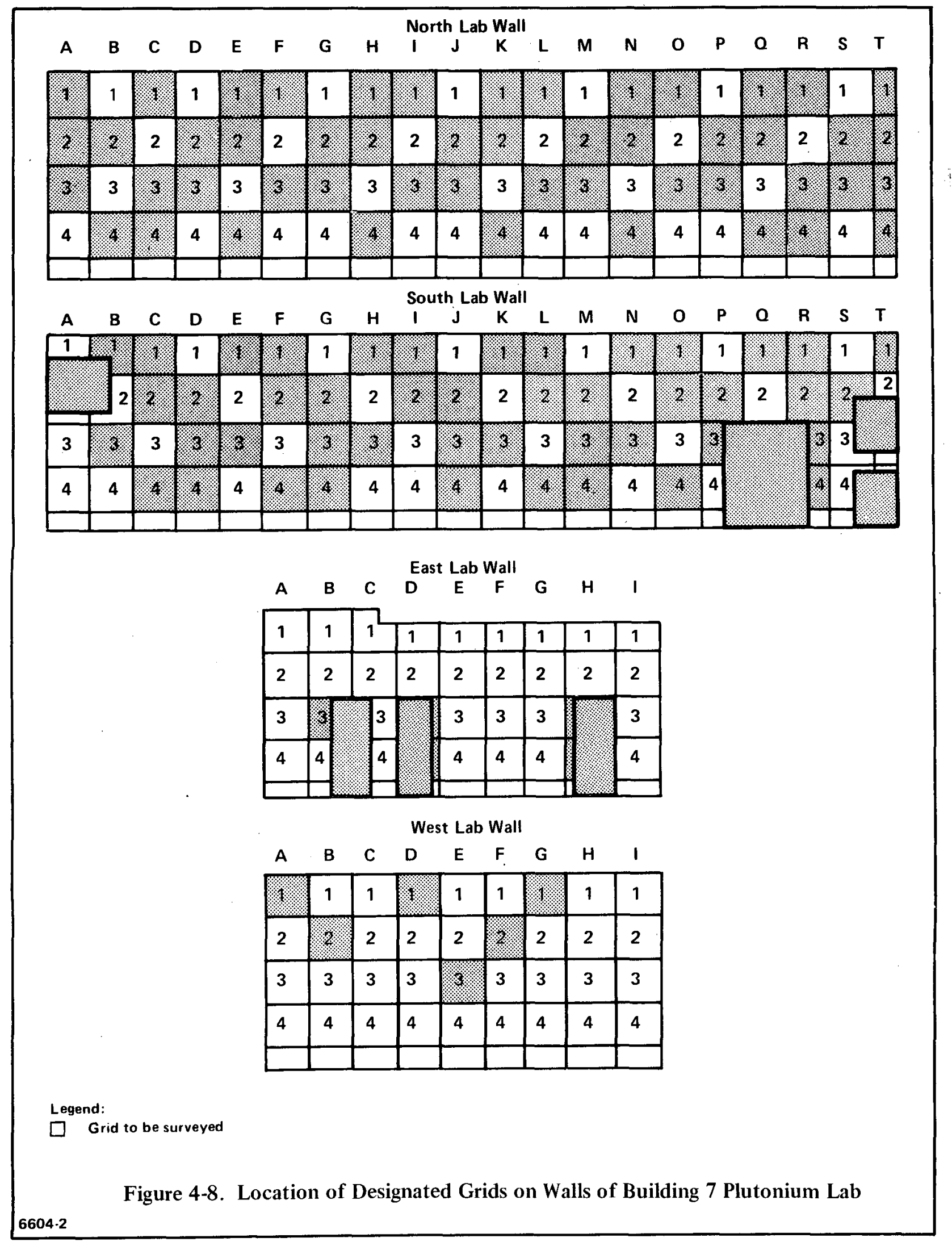


Floor, Pu Lab, Bldg. \#7

North

\begin{tabular}{|c|c|c|c|c|c|c|c|c|c|c|c|c|c|c|c|c|c|c|c|}
\hline $\mathbf{T}$ & $\mathbf{S}$ & $\mathbf{R}$ & $\mathbf{0}$ & $P$ & 0 & $\mathbf{N}$ & $\mathbf{M}$ & $\mathbf{L}$ & $\mathbf{K}$ & $\mathbf{J}$ & I & H & $\mathbf{G}$ & $\mathbf{F}$ & $\mathbf{E}$ & D & C & B & A \\
\hline 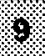 & 4 & 8 & 9 & 13 & 19 & S9 & 9 & 9 & 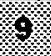 & 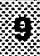 & $\frac{1}{3}$ & 9 & $\%$ & 8 & K & 19 & 9 & (9) & 4 \\
\hline 8 & 8 & 8 & 8 & 86 & 畨 & 楼 & 8 & 8 & 8 & 楼 & K) & 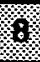 & $\%$ & 8 & 6 & 8 & 畨 & 8 & 8 \\
\hline \% & 4 & 4 & $1 \%$ & 7 & $1 \%$ & 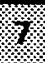 & 7 & 1 & 1 & 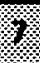 & 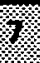 & \% & K & 样 & 7 & $\%$ & \% & \% & 11 \\
\hline $6 \%$ & 6 & 6 & 6 & 6 & 6 & 6 & 8 & 6 & 6 & 6. & 6 & 8 & 6 & 8 & 6 & 8 & $\%$ & 6 & $\frac{1}{6}$ \\
\hline 8 & 6 & 5 & 5 & 66 & 5 & 5 & K) & 5 & 5 & 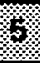 & 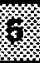 & 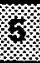 & 3 & 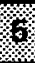 & 19 & 10. & 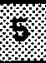 & 5 & $\%$ \\
\hline 4 & 14 & 9 & $8 \%$ & 14 & 4 & 4 & 46 & 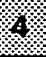 & \% & 4 & $\%$ & $\%$ & 4 & 4 & 6 & 4 & $\%$ & . & 4 \\
\hline$\%$ & 8 & $\%$ & 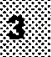 & (1) & 3 & 3 & 6 & 棪 & Ko & 3 & 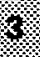 & 3 & K & 3 & 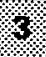 & \% & $\%$ & 3 & $\%$ \\
\hline$\%$ & 8 & 2 & $\%$ & $\%$ & 2. & 2 & 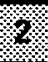 & 2 & $\%$ & 1 & 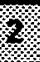 & \% & K & 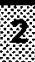 & 2 & 4 & 8 & 将 & 2 \\
\hline 1 & $1 /$ & 格 & \% & 1 & \% & $\frac{1}{1}$ & K & . & 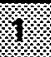 & 1 & 楼 & 楼 & K & 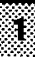 & \% & 4 & 1 & 4 & K \\
\hline
\end{tabular}

\begin{tabular}{|l|l} 
Rear & South
\end{tabular}

Door

North

\begin{tabular}{|c|c|c|c|c|c|c|c|c|c|c|c|}
\hline $\mathbf{L}$ & $\mathbf{K}$ & $\mathbf{J}$ & 1 & H & $\mathbf{G}$ & $\mathbf{F}$ & $E$ & D & C & $\mathbf{B}$ & A \\
\hline 45 & 15 & 10 & 15 & 15 & 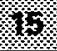 & 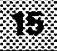 & 15 & . & 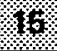 & 45 & 16 \\
\hline$\sqrt{14}$ & 14 & 14 & 14 & $1 \%$ & 4 & $\%$ & KK & 8 & $\%$ & 14 & $4 \%$ \\
\hline 8 & 3 & 13 & 18 & 18 & 8 & 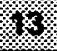 & 16 & 13 & 18 & $\%$ & 将 \\
\hline 12 & 12 & 18 & 12 & $1 \%$ & \% & 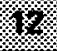 & 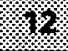 & 17 & 12 & 1 & Y2. \\
\hline $1 \%$ & 1 & 11 & 11 & $\%$ & 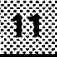 & 楼 & 约 & 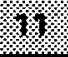 & $\%$ & 18 & 11 \\
\hline 10 & 10 & 10 & 113 & 10 & 10 & (6) & 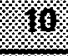 & 6 & 18 & 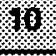 & 10 \\
\hline 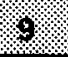 & 3 & \% & 9 & 9 & 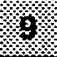 & 新 & 8 & 9 & 9 & $\%$ & 8 \\
\hline 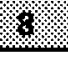 & 8 & 8 & 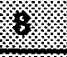 & 8 & 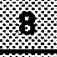 & 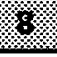 & 6 & 8 & \% & 8 & 30 \\
\hline 7 & V. & V. & & 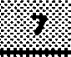 & \% & 7 & . & , & 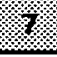 & 8 & $\%$ \\
\hline 8 & 86 & 6 & 6 & 6 & 6 & . & 格 & 6 & 6 & 6 & 5 \\
\hline \% & 5 & 4 & 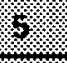 & 5 & 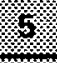 & $\%$ & 5 & 6 & $\%$ & \% & 8 \\
\hline 4 & 4 & 4 & 溇 & 4 & $\%$ & 滀 & א. & 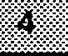 & 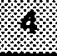 & 8 & 4 \\
\hline 8 & 8 & 3 & 3 & 3 & \% & 3 & \% & \% & 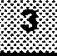 & $\%$ & 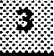 \\
\hline$\%$ & 2 & \% & 2 & 6 & 2 & 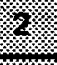 & 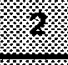 & 2 & 8 & $\%$ & 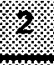 \\
\hline צ. & Y & \% & 1 & \% & x & 林 & 椾 & \% & א. & 1 & $\%$ \\
\hline
\end{tabular}

Legend:

South

$\square$ Grid to be surveyed

Figure 4-9. Location of Designated Grids on Floor and Inside Surface of Roof, Building 7 Plutonium Lab 


\begin{tabular}{|c|c|c|c|c|}
\hline \multicolumn{3}{|c|}{ South Wall } & \multicolumn{2}{|c|}{ West Wall } \\
\hline $\mathbf{A}$ & B & C & $\mathbf{A}$ & $\mathbf{B}$ \\
\hline 1 & & 1 & 1 & 1 \\
\hline 2 & 2 & 2 & 2 & \\
\hline 3 & & 3 & 3 & \\
\hline
\end{tabular}

Visitors Entrance

Floor

A B C

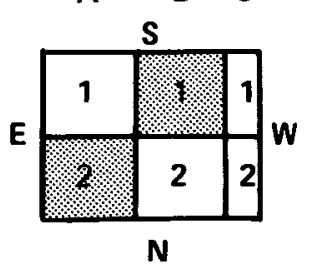

South Wall
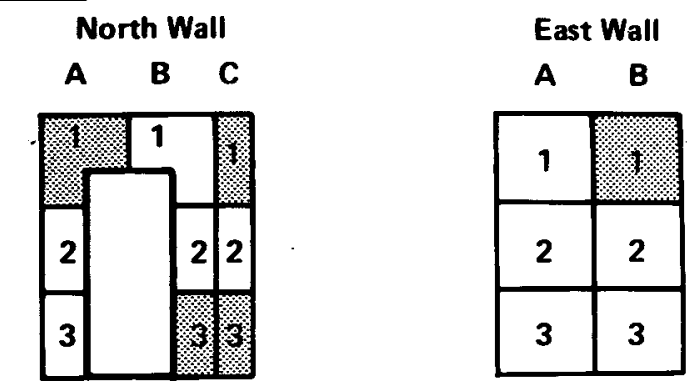

\begin{tabular}{|c|c|c|c|c|c|}
\hline \multicolumn{6}{|c|}{ South Wall } \\
\hline A & B & C & D & $E$ & $\boldsymbol{F}$ \\
\hline 1 & $\%$ & 1 & 4 & 1 & \% \\
\hline \% & 2 & 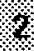 & 2 & 1 & 2 \\
\hline 3 & 3 & 3 & 3 & 3 & 3 \\
\hline 4 & 4 & $\%$ & 4 & 4 & 4 \\
\hline
\end{tabular}

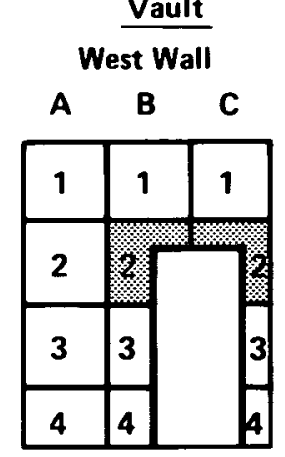

Ceiling

A B C

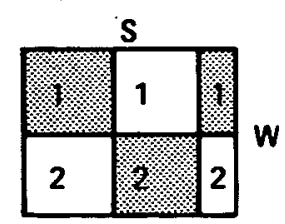

Vault $\quad N$

West Wall
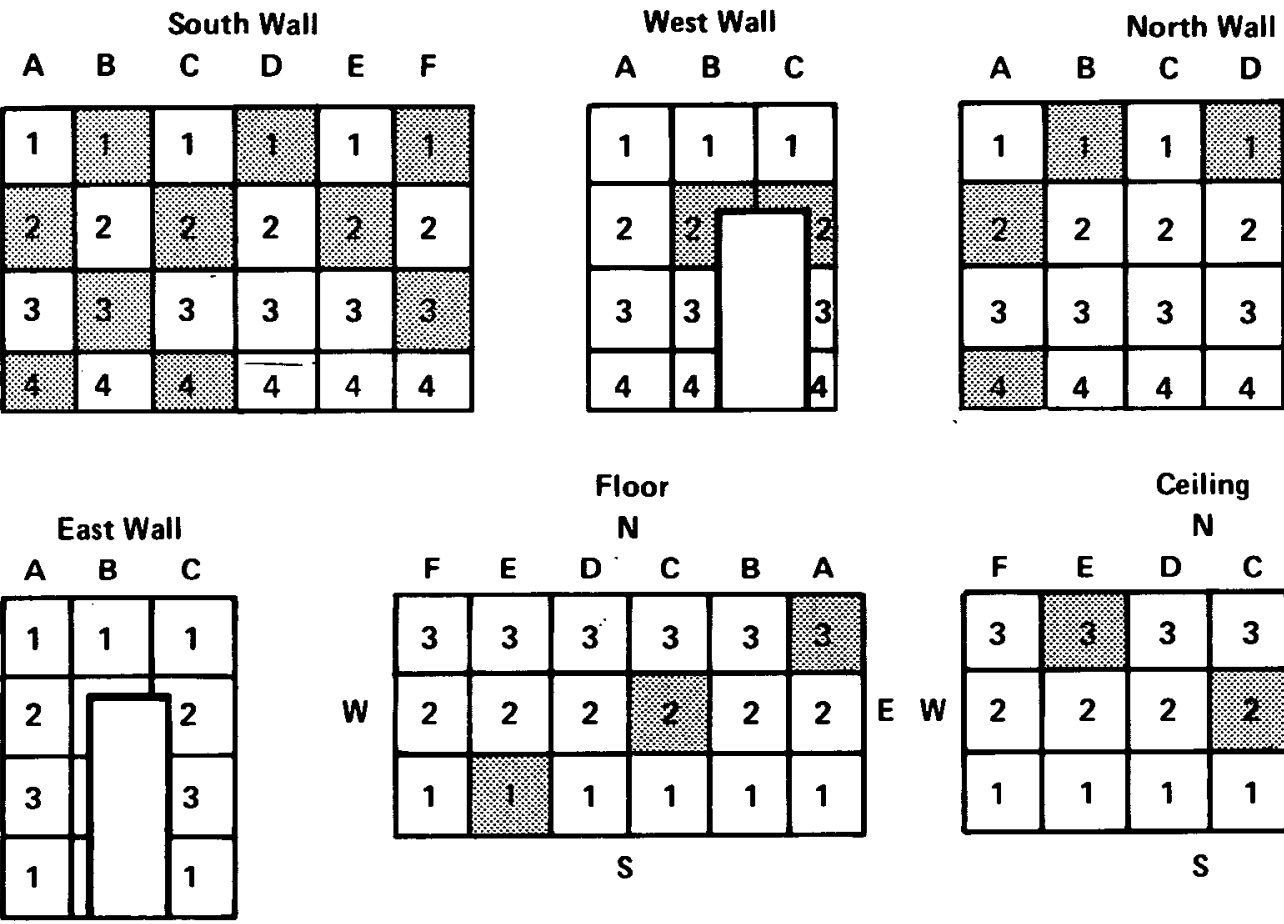

\begin{tabular}{|c|c|c|c|c|c|}
\hline A & B & C & D & $\mathbf{E}$ & $F$ \\
\hline 1 & $\%$ & 1 & 8 & 1 & 1 \\
\hline 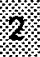 & 2 & 2 & 2 & 2 & 2 \\
\hline 3 & 3 & 3 & 3 & 3 & 3 \\
\hline$\gamma$ & 4 & 4 & 4 & 4 & 4 \\
\hline
\end{tabular}

Legend:

$\square$ Grid to be surveyed

Figure 4-10. Location of Designated Grids on All Surfaces of Visitors Entrance and Vault 6604-1 Peripheral Service Areas for Building 7 Plutonium Lab Final Survey 


\begin{tabular}{|c|c|c|c|}
\hline \multicolumn{4}{|c|}{ South Wall } \\
\hline A & B & C & D \\
\hline 1 & 1 & 1 & \% \\
\hline 4 & 2 & \% & 2 \\
\hline 3 & 3 & 3 & 4 \\
\hline
\end{tabular}
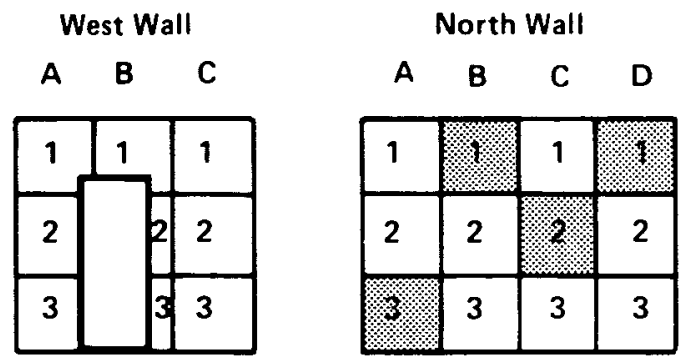

East Wall
\begin{tabular}{|l|l|l|}
\hline A & B & C \\
\hline 1 & 1 & 1 \\
\hline 2 & & 2 \\
\hline 3 & & 3 \\
\hline
\end{tabular}

Floor $\mathrm{N}$

D $\quad$ C $\quad$ B $\quad$ A
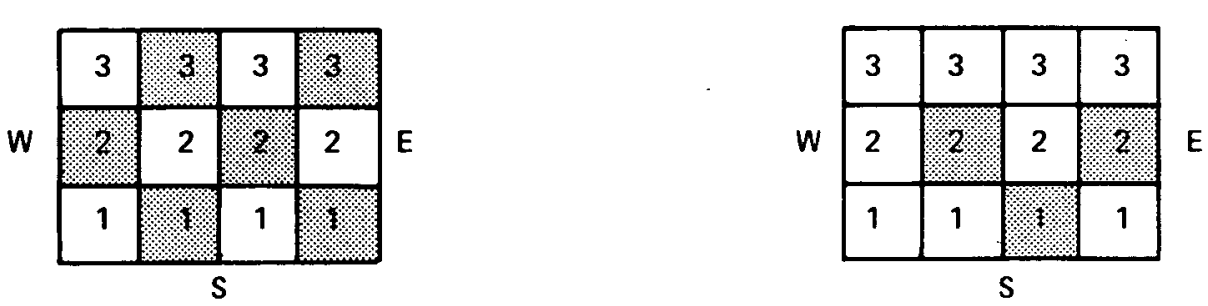

Rear Air Lock Entrance

South Wall

A B

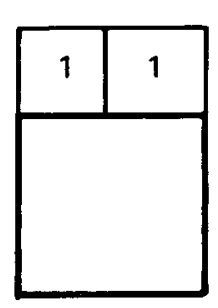

\begin{tabular}{|c|c|c|}
\hline A & B & C \\
\hline 1 & 1 & 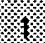 \\
\hline 2 & 2 & 2 \\
\hline 3 & 3 & 3 \\
\hline
\end{tabular}

North Wall

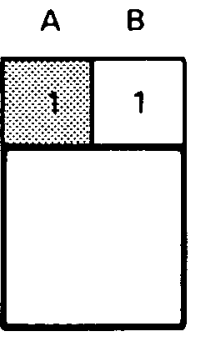

\begin{tabular}{|c|c|c|}
\hline \multicolumn{3}{|c|}{ East Wall } \\
\hline A & B & C \\
\hline 1 & 1 & 1 \\
\hline 2 & 2 & 2 \\
\hline 3 & 3 & 3 \\
\hline
\end{tabular}

Floor $\mathbf{N}$

Ceiling N

A $\quad$ B
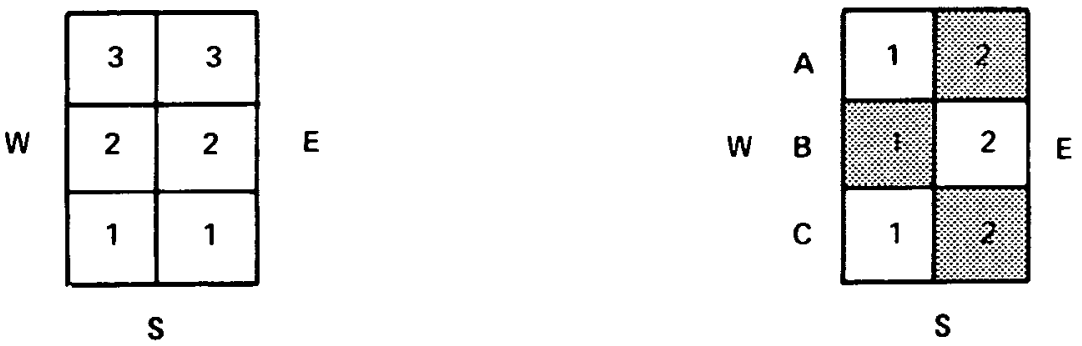

Legend:

$\square$ Grid to be surveyed

Figure 4-11. Location of Designated Grids on All Surfaces of Lavatory and Rear Air Lock $6604-4$ Entrance Peripheral Service Areas for Building 7 Plutonium Lab 
All final survey surface measurement results in Building 7 were negative, which indicates that none of the $P A C-4 G$ alpha survey results were above background levels, and none of the wall surface smear results were above the minimum detectable activity level. All measurements of total activity in the holes and penetrations of walls and ceiling were well below the specified limit of $250 \mathrm{dpm}$. The exposed TLDs showed an average of $0.0077 \mathrm{mrem} / \mathrm{hr}$ and $0.0104 \mathrm{mrem} / \mathrm{hr}$ for the laboratory and peripheral areas respectively, and maximum levels of 0.015 and 0.018 in laboratory and peripheral areas, respectively. No activity above permissible levels was found in any of the miscellaneous surface areas.

In summary, preliminary surveys of the Building 7 plutonium laboratory and peripheral support areas showed only three small spots of the laboratory floor which were cleaned and decontaminated to below average permissible limits (<100 dpm/100 $\mathrm{cm}^{2}$ total $\alpha$ or $\leq 20 \mathrm{dpm} / 100 \mathrm{~cm}^{2}$ removable) according to the SNM-1120 1icense criteria and ANSI Standard 13.12. The final survey showed no areas with contamination above background levels. 


\subsection{CONCLUSIONS AND RECOMMENDATIONS}

\subsection{CONCLUSIONS}

The ARD Fuel Laboratories at Cheswick have been decontaminated/decommissioned in accordance with the requirements set forth in ANSI Standard 13.12 and License SNM-1120. Since these facilities can be returned to unrestricted use, Westinghouse ARD believes that the program objectives have been met.

\subsection{RECOMMENDATIONS}

ARD would like to offer the following recommendations for DOE consideration:

A. Assessment of the two methods of glove box disposal, specifically volume reduction and whole box, should be made from the standpoint of cost, schedule, and volume of waste generated to determine the better method. This assessment may be possible by comparing information developed by BMI Columbus, which used volume reduction, and information contained in this report covering the whole box technique.

B. In the event that the whole box technique is utilized in future programs, consideration should be given to loading the inside chamber of the glove box with small tools, equipment, etc., and foaming this in place to minimize the overall volume of waste produced thus reducing the quantity of waste for shipping and burial. 
APPENDIX A

SUMMARY OF PROCEDURES AND DATA

FORMS FOR THE MITS

A-1 
$\theta$

$\bullet$ 


\begin{tabular}{|c|c|}
\hline \multicolumn{2}{|r|}{$\begin{array}{c}\text { TABLE A-1 } \\
\text { MIT } 3095 \\
\text { SEGREGATION, REMOVAL, IDENTIFICATION \& NDA OF } \\
\text { GLOVE BOX WASTE (TEMPORARY STORAGE) }\end{array}$} \\
\hline Procedure/Form & Title \\
\hline PIDS 3095 & $\begin{array}{l}\text { Segregation, Removal, Identification \& NDA of Glove } \\
\text { Box Waste (Temporary Storage) }\end{array}$ \\
\hline PFDL-0P-0003 & $\begin{array}{l}\text { Treatment, Collection \& Segregation of Wastes for } \\
\text { Disposal }\end{array}$ \\
\hline $\begin{array}{l}\text { ARD Pu Lab } \\
\text { OP-11-800 }\end{array}$ & $\begin{array}{l}\text { General Operating Procedure for the ARD Advanced Fuel } \\
\text { Laboratory }\end{array}$ \\
\hline PFDL-TI -0043 & Tamper Safeing Containers \\
\hline QIP-DQA-E- 1101 & Processing Document Review \\
\hline PFDL-AL-0023 & $\begin{array}{l}\text { Determination of Plutonium/Uranium in Low-Level Waste } \\
\text { by Gamma Spectrometry }\end{array}$ \\
\hline PFDL Form 056 & Waste Shipping Container Log Sheet \\
\hline
\end{tabular}


TABLE A-2

MIT 3096

FINAL PACKAGING OF TYPES $A, B, C \& D$ WASTE FOR SHIPMENT

TO PERMANENT STORAGE DOE/RICHLAND BURIAL SITE

\begin{tabular}{|l|l|}
\hline Procedure/Form & \multicolumn{1}{c|}{ Title } \\
\hline PIDS 3096 & $\begin{array}{l}\text { Final Packaging of Types A, B, C \& D Waste for Ship- } \\
\text { ment to Permanent Storage DOE/Richland Burial Site }\end{array}$ \\
OI-3911 & $\begin{array}{l}\text { Material Control at Cheswick } \\
\text { Packaging of Waste Containers for Shipment to the } \\
\text { Rockwe11 Hanford Operations Site }\end{array}$ \\
PFDL-OP-D-0811 & $\begin{array}{l}\text { Foaming Waste Packages } \\
\text { Tamper Safeing Containers }\end{array}$ \\
QIP-DQL-TI-0043 & $\begin{array}{l}\text { Inspection of Rigid Urethane Foam Waste Fixing in DOT } \\
\text { 17C Drums }\end{array}$ \\
PFDL-OP-0217 & $\begin{array}{l}\text { Packaging, Labeling \& Marking Requirements for Low- } \\
\text { Level Waste Shipments Transported in the Model No. } \\
6400 \text { to the Rockwel1 Hanford Operations/DOE-Richland, } \\
\text { Washington Site } \\
\text { Waste Shipping Container Log Sheet } \\
\text { Processing Document Review }\end{array}$ \\
\hline
\end{tabular}




\begin{tabular}{|c|c|}
\hline \multicolumn{2}{|c|}{$\begin{array}{c}\text { MIT } 3097 \\
\text { PREFOAMING OF DOT } 17 C \text { DRUMS FOR SHIPMENT OF WNASTE }\end{array}$} \\
\hline & Title \\
\hline PROCEDURE & \\
\hline OI -391$]$ & Material Control at ARD Cheswick \\
\hline QIP-DQA-E-3009 & $\begin{array}{l}\text { Inspection of Rigid Urethane Foam Waste Fixing in } \\
\text { DOT } 17 C \text { Drums }\end{array}$ \\
\hline PFDL-OP-D-0811 & Foaming Waste Packages \\
\hline QIP-DQA-E-1101 & Processing Document Review \\
\hline DATA FORM & \\
\hline PIDS-3097 & Prefoaming of DOT $17 \mathrm{C}$ Drums for Shipment of waste \\
\hline
\end{tabular}


TABLE A-4

MIT 3098

SHIPMENT OF PERMANENT WASTE STORAGE DRUMS IN MODEL 6400 OVERPACK

\begin{tabular}{|c|c|}
\hline Procedure/Form & Title \\
\hline PIDS 3098 & $\begin{array}{l}\text { Shipment of Permanent Waste Storage Drums in Model } \\
6400 \text { Overpack }\end{array}$ \\
\hline USNRC $6400 / B$ & Packaging Model No. 6400 Overpack \\
\hline PFDL-OP-0003 & $\begin{array}{l}\text { Treatment, Collection \& Segregation of Wastes for } \\
\text { Disposal }\end{array}$ \\
\hline PFDL-0P-0200 & $\begin{array}{l}\text { Packaging \& Labeling Requirements for Radioactive } \\
\text { Material Shipment }\end{array}$ \\
\hline PFDL-0P-0201 & Shipment of Radioactive Materials \\
\hline PFDL-0P-0216 & $\begin{array}{l}\text { Radioactive Material Transportation Notification } \\
\text { Requirements }\end{array}$ \\
\hline PFDL-0P-0217 & $\begin{array}{l}\text { Packaging, Labeling \& Marking Requirements for Low- } \\
\text { Level Waste Shipments Transported in the Mode } 1 \text { No. } \\
6400 \text { Overpack to the Rockwe } 11 \text { Hanford Operations/DOE- } \\
\text { Richland, Washington Site }\end{array}$ \\
\hline$Q I P-D Q A-E-3009$ & $\begin{array}{l}\text { Inspection of Rigid Urethane Foam Waste Fixing in DOT } \\
17 C \text { Drums }\end{array}$ \\
\hline PFDL-TI-0043 & Tamper Safeing Containers \\
\hline QIP-DQA-E-1101 & Process Document Review \\
\hline PFDL Form 008 & $\begin{array}{l}\text { Westinghouse Plutonium Fuels Development Laboratory } \\
\text { Radioactive Shipment Container Checklist }\end{array}$ \\
\hline PFDL Form 045 & Radioactive Shipment Record \\
\hline PFDL Form 084 & $\begin{array}{l}\text { D0T } 17 \mathrm{H} \& 17 \mathrm{C} \text { Shipping Container Checklist - } \\
\text { Transuranics }\end{array}$ \\
\hline PFDL Form 091 & Radioactive Shipment Record \\
\hline PFDL Form 092 & $\begin{array}{l}\text { Instructions to Carrier for Maintenance of Exclusive } \\
\text { Use Shipmen Controls }\end{array}$ \\
\hline W Form 46236 & Bill of Lading - Shipping \\
\hline $\begin{array}{l}\text { RHO Form 54-3000- } \\
\quad 581\end{array}$ & Solid Waste Burial Record \\
\hline $\begin{array}{l}\text { RHO Form BC-6800- } \\
076\end{array}$ & Transuranic Dry Waste Storage \\
\hline
\end{tabular}




\begin{tabular}{|l|c|}
\hline \multicolumn{1}{|c|}{ TABLE A-5 } \\
MIT 3099 \\
DECONTAMINATION, FI XATION, PREPARATION FOR REMOVAL, REMOVAL AND \\
NDA OI GLOVE BOXES AND EQUIPMENT
\end{tabular}


TABLE A-6

MIT 3100

SHIPMENT OF STEEL BINS IN MODEL 6272 OVERPACK TO ROCKWELL HANFORD OPERATIONS

\begin{tabular}{|c|c|}
\hline Procedure/Form & Title \\
\hline PIDS 3100 & $\begin{array}{l}\text { Shipment of Steel Bins in Model } 6272 \text { Overpack to } \\
\text { Rockwell Hanford Operations }\end{array}$ \\
\hline USNRC $6272 / B$ & Packaging Model No. 6272 Overpack \\
\hline PFDL-OP-0003 & $\begin{array}{l}\text { Treatment, Collection \& Segregation of Wastes for } \\
\text { Disposal }\end{array}$ \\
\hline PFDL-OP-0200 & $\begin{array}{l}\text { Packaging \& Labeling Requirements for Radioactive } \\
\text { Material Shipment }\end{array}$ \\
\hline PFDL-0P-0201 & Shipment of Radioactive Materials \\
\hline PFDL-0P-0216 & $\begin{array}{l}\text { Radioactive Material Transportation Notification } \\
\text { Requirements }\end{array}$ \\
\hline PFDL-OP-0218 & $\begin{array}{l}\text { Packaging, Labeling \& Marking Requirements for Low- } \\
\text { Level Waste Shipments Transported in the Model No. } \\
6272 \text { Overpack to the Rockwell Hanford Operations/DOE- } \\
\text { Richland, Washington Site }\end{array}$ \\
\hline PFDL Form 008 & W PFDL Radioactive Shipment Container Checklist \\
\hline PFDL Form 045 & PFDL Radioactive Shipment Record \\
\hline PFDL Form 091 & PFDL Radioactive Shipment Record \\
\hline PFDL Form 092 & $\begin{array}{l}\text { Instructions to Carrier for Maintenance of Exclusive } \\
\text { Use Shipment Controls }\end{array}$ \\
\hline PFDL Form 093 & M-III Bin Shipping Container Checklist \\
\hline W Form 46236 & Bill of Lading - Shipping \\
\hline $\begin{array}{l}\text { RHO Form 54- } \\
3000-581\end{array}$ & Solid Waste Burial Record \\
\hline $\begin{array}{l}\text { RHO Form BC- } \\
6800-076\end{array}$ & Transuranic Dry Waste Storage \\
\hline
\end{tabular}


TABLE A-7

MIT 3101

PACKAGING STEEL BINS FOR SHIPMENT TO ROCKWELL

HANFORD OPERATINNS

\begin{tabular}{|c|c|}
\hline Procedure/Form & Title \\
\hline PFDL-0P-D-0816 & $\begin{array}{l}\text { Packaging of Waste Containers for Shipments to the } \\
\text { Rockwell Hanford Operations Site }\end{array}$ \\
\hline PFDL-TI -0043 & Tamper Safeing Containers \\
\hline PFDL-0P-0218 & $\begin{array}{l}\text { Packaging, Labeling, Marking Requirements for Low- } \\
\text { Level Waste Shipments Transported in the Model No. } \\
6272 \text { Overpack to the Rockwe } 11 \text { Hanford Operations/ } \\
\text { DOE Richland, Washington Site }\end{array}$ \\
\hline QIP-DQA-E-1101 & Processing Document Review \\
\hline PFDL Form 093 & M-III Bin Shipping Container Checklist-Transuranic \\
\hline
\end{tabular}


TABLE $A-8$

MIT 3102

BUILDING 8 PURIFIER REMOVAL \& NDA

\begin{tabular}{|l|l|}
\hline Procedure/Form & \multicolumn{1}{|c|}{ Title } \\
\hline ARD PFDL-SP-06-10-80 & Disconnection \& Removal of Purifiers \\
PFDL-AL-D-0057 & $\begin{array}{l}\text { Assay of SNM Holdup in Glove Boxes by } \\
\text { Gamma Spectrometry } \\
\text { QIP-DQA-E-1101 }\end{array}$ \\
\hline
\end{tabular}




\begin{tabular}{|c|c|}
\hline \multicolumn{2}{|c|}{$\begin{array}{c}\text { TABLE A-9 } \\
\text { MIT } 3103 \\
\text { LARGE EQUIPMENT REMOVAL FROM GLOVE BOX }\end{array}$} \\
\hline Procedure/Form & \\
\hline PFDL-0P-D-0813 & Removal of Large Equipment from Glove Boxes \\
\hline QIP-DQA-E-1101 & Processing Document Review \\
\hline ARD-Pu Lab OP-11-700 & $\begin{array}{l}\text { General Operating Procedure for ARD Plutonium } \\
\text { Laboratory }\end{array}$ \\
\hline ARD-Pu Lab OP- $11-800$ & $\begin{array}{l}\text { General Operating Procedure for ARD Advanced } \\
\text { Fuel Laboratory }\end{array}$ \\
\hline PIDS 3103, Rev. 0 & Large Equipment Removal from Glove Box \\
\hline
\end{tabular}


TABLE A-10

MIT 3104

LOADING STEEL BINS WITH DRUMS FOR SHIPMENT TO ROCKWELL HANFORD

\begin{tabular}{|c|c|}
\hline & Title \\
\hline \multicolumn{2}{|l|}{ PROCEDURE } \\
\hline $0 I-3911$ & Material Control at ARD Cheswick \\
\hline PFDL-0P-0218 & $\begin{array}{l}\text { Packaging, Labeling, and Marking Requirements for Low- } \\
\text { Level Waste Shipments Transported in the Model No. } 6272 \\
\text { Overpack to the Rockwell Hanford Operations/DOE-Rich- } \\
\text { land, Washington Site }\end{array}$ \\
\hline PFDL-OP-D-0816 & $\begin{array}{l}\text { Packaging of Waste Containers for Shipment to the } \\
\text { Rockwell Hanford Operations Site }\end{array}$ \\
\hline PFDL-TI-0043 & Tamper Safeing Containers \\
\hline PFDL-0P-0200 & $\begin{array}{l}\text { Packaging and Labeling Requirements for Radioactive } \\
\text { Material Shipment }\end{array}$ \\
\hline PFDL-nP-0201 & Shipment of Radioactive Materials \\
\hline QIP-DQA-E- 1101 & Processing Document Review \\
\hline \multicolumn{2}{|l|}{ DATA FORM } \\
\hline PIDS 3098 & $\begin{array}{l}\text { Shipment of Permanent Storage Drums in Mode } 16400 \\
\text { Overpack }\end{array}$ \\
\hline PFDL Form 084 & $\begin{array}{l}\text { D0T } 17 \mathrm{H} \text { and } 17 \mathrm{C} \text { Shipping Container Checklist- } \\
\text { Transuranics }\end{array}$ \\
\hline PFDL Form 094 & $\begin{array}{l}\text { M-III Bin Shipping Container Checklist-Drum Transport- } \\
\text { Transuranics }\end{array}$ \\
\hline
\end{tabular}


TABLE A-11

MIT 3705

SHIPMENT OF DRUM TRANSPORT BINS IN MODEL 6272 OVERPACKS TO

ROCKWELL HANFORD OPERATIONS

\begin{tabular}{|c|c|}
\hline & Title \\
\hline \multicolumn{2}{|l|}{ PROCEDURE } \\
\hline PFDL-0P-0218 & $\begin{array}{l}\text { Packaging, Labeling, and Marking Requirements for Low- } \\
\text { Level Waste Shipments Transported in the Model No. } \\
6272 \text { Overpack to the Rockwell Hanford Operations/DOE- } \\
\text { Richland, Washington Site }\end{array}$ \\
\hline PFDL-0P-0200 & $\begin{array}{l}\text { Packaging and Labeling Requirements for Radioactive } \\
\text { Material Shipment }\end{array}$ \\
\hline PFDL-0P-0201 & Shipment of Radioactive Materials \\
\hline PFDL-TI-0043 & Tamper Safeing Containers \\
\hline QIP-DQA-E-1101 & Processing Document Review \\
\hline USNRC 6272 , Rev. 3 & $\begin{array}{l}\text { Certificate of Compliance for Model } 6272 \text { (Poly Panther) } \\
\text { Overpack }\end{array}$ \\
\hline \multicolumn{2}{|l|}{ DATA FORMS } \\
\hline RHO Form BC-6800-076 & Transuranic Dry Waste Storage \\
\hline RHO Form 54-3000-581 & Solid Waste Burial Record \\
\hline PFDL Form 091 & Radioactive Shipment Record \\
\hline PFDL Form 045 & Radioactive Shipment Record \\
\hline W Form 46236 & Hazardous Materials Bill of Lading \\
\hline PFDL Form 008 & Radioactive Shipment Container Checklist \\
\hline PFDL Form 092 & Exclusive Use of Vehicle \\
\hline
\end{tabular}


TABLE $A-12$

MIT 3019

TEMPORARY STORAGE AND NDA OF WASTE PACKAGES

\begin{tabular}{|c|c|}
\hline & Title \\
\hline \multicolumn{2}{|l|}{ PROCEDURE } \\
\hline PFDL-0P-D-0828 & $\begin{array}{l}\text { Assigning Unique Identification Numbers to Waste } \\
\text { Packages }\end{array}$ \\
\hline PFDL-0P-0003 & $\begin{array}{l}\text { Treatment, Collection, and Segregation of Wastes for } \\
\text { Disposal }\end{array}$ \\
\hline PFDL-OP-D-0819 & Disposal of Plutonium Contaminated Liquid Organics \\
\hline PFDL-TI-0043 & Tamper Safeing Containers \\
\hline PFDL-OP-D-0829 & $\begin{array}{l}\text { Transfer of Contaminated Equipment Between Buildings } \\
7 \text { and } 8\end{array}$ \\
\hline PFDL-AL-0023 & $\begin{array}{l}\text { Determination of Pu/U in Low-Level Waste by Gamma } \\
\text { Spectrometry }\end{array}$ \\
\hline PFDL-AL-D-0057 & $\begin{array}{l}\text { Assay of SNM Holdup in Glove Boxes by Gamma Spectro- } \\
\text { metry }\end{array}$ \\
\hline QIP-DQA-E- 1101 & Processing Document Review \\
\hline DATA FORM & \\
\hline PFDL Form 096 & Log Sheet for Waste Packages \\
\hline PFDL Form 056 & Waste Shipping Container Log Sheet \\
\hline
\end{tabular}


TABLE A-13

MIT 3110

FINAL PACKAGING OF TRANSURANIC WASTE INTO PERMANENT SHIPPING DRUMS

\begin{tabular}{|c|c|}
\hline & Title \\
\hline \multicolumn{2}{|l|}{ PROCEDURE } \\
\hline OI-3911 & Material Control at ARD Cheswick \\
\hline PFDL-0P-D-0816 & $\begin{array}{l}\text { Packaging of Waste Containers for Shipment to the } \\
\text { Rockwell Hanford Operations Site }\end{array}$ \\
\hline PFDL-0P-D-0811 & Foaming Waste Packages \\
\hline QIP-DQA-E-3009 & $\begin{array}{l}\text { Inspection of Rigid Urethane Foam Waste Fixing in DOT } \\
17 C \text { Drums }\end{array}$ \\
\hline PFDL-TI-0043 & Tamper Safeing Containers \\
\hline PFDL-OP-0217 & $\begin{array}{l}\text { Packaging, Labeling, and Marking Requirements for } \\
\text { Low-Level Waste Shipments Transported in the Model } \\
\text { No. } 6400 \text { Overpack to the Rockwell Hanford Operations/ } \\
\text { DOE-Richland, Washington Site }\end{array}$ \\
\hline QIP-DQA-E-1101 & Processing Document Review \\
\hline \multicolumn{2}{|l|}{ DATA FORM } \\
\hline PIDS 3110 & $\begin{array}{l}\text { Final Packaging of Transuranic Waste into Permanent } \\
\text { Shipping Drums }\end{array}$ \\
\hline PFDL Form 056 & Waste Shipping Container Log Sheet \\
\hline PFDL Form 084 & $\begin{array}{l}\text { DOT } 17 \mathrm{H} \text { and } 17 \mathrm{C} \text { Shipping Container Checklist - } \\
\text { Transuranic }\end{array}$ \\
\hline
\end{tabular}


TABLE $A-14$

MIT 3111

PACKAGING FRP COATED PLYWOOD BOXES

\section{Title}

PROCEDURE

OI-3911

Material Control at ARD Cheswick

PFDL-OP-D-0830

Packaging FRP Coated Plywood Boxes

PFDL-OP-D-0811

Foaming Waste Packages

PFDL-OP-D-0833

Application of Fiberglass Seal to FRP Coated Plywood Boxes

QIP-DQA-E- 1101

Processing Document Review

DATA FORM

PFDL Form 095

FRP Coated Plywood Box Checklist - Transuranics 


\begin{tabular}{|l|}
\hline \multicolumn{2}{|c|}{ TABLE A-15 } \\
MIT 3112 \\
\multicolumn{2}{|c|}{ RELEASE AND USE OF POLYURETHANE FOAM } \\
\hline \\
\hline OI-3911 \\
QIP-DQA-E-1101
\end{tabular}




\begin{tabular}{|c|c|}
\hline \multicolumn{2}{|c|}{$\begin{array}{c}\text { TABLE A-16 } \\
\text { MIT } 3113 \\
\text { SHIPPING FRP'S TO ROCKWELL HANFORD OPERATIONS } \\
\text { IN MODEL NO. } 6400 \text { OVERPACKS }\end{array}$} \\
\hline & Title \\
\hline \multicolumn{2}{|l|}{ PROCEDURE } \\
\hline PFDL-0P-0217 & $\begin{array}{l}\text { Packaging, Labeling, and Marking Requirements for Low- } \\
\text { Level Waste Shipments Transported in the Model No. } 6400 \\
\text { Overpack to the Rockwell Hanford Operations/DOE-Rich- } \\
\text { land, Washington Site }\end{array}$ \\
\hline $0 I-3911$ & Material Control at ARD Cheswick \\
\hline PFDL-OP-0201 & Shipment of Radioactive Materials \\
\hline PFDL-TI-0043 & Tamper Safeing Containers \\
\hline PFDL-0P-0200 & $\begin{array}{l}\text { Packaging and Labeling Requirements for Radioactive } \\
\text { Material Shipment }\end{array}$ \\
\hline QIP-DQA-E-1101 & Processing Document Review \\
\hline USNRC 6400 & $\begin{array}{l}\text { Mode1 } 6400 \text { Overpack Exemption Letter, dated Jan. } 26 \text {, } \\
\text { 1981. }\end{array}$ \\
\hline \multicolumn{2}{|l|}{ DATA FORM } \\
\hline PFDL Form 095 & FRP Coated Plywood Box Checklist - Transuranics \\
\hline PFDL Form 008 & Radioactive Shipment Container Checklist \\
\hline PFDL Form 091 & Radioactive Shipment Record \\
\hline RHO Form BC-6800-076 & Transuranic Dry Waste Storage \\
\hline RHO Form $54-3000-581$ & Solid Waste Burial Record \\
\hline PFDL Form 045 & Radioactive Shipment Record \\
\hline W Form 46236 & Hazardous Materilas Bill of Lading \\
\hline PFDL Form 092 & $\begin{array}{l}\text { Radioactive Shipment Record - Instructions to Carrier } \\
\text { for Exclusive Use }\end{array}$ \\
\hline
\end{tabular}




\begin{tabular}{|c|c|}
\hline & $\begin{array}{c}\text { TABLE A-17 } \\
\text { MIT } 3114 \\
\text { REPAIR OF GALVANIZED DRUMS }\end{array}$ \\
\hline & Title \\
\hline PROCEDURE & \\
\hline $0 I-3911$ & Materials Control at ARD Cheswick \\
\hline PFDL-0P-D-0831 & Repair of Galvanized Drums \\
\hline QIP-DQA-E- 1101 & Processing Document Review \\
\hline DATA FORM & \\
\hline PIDS 3114 & Repair of Galvanized Drums \\
\hline
\end{tabular}




\begin{tabular}{|l|c|}
\hline \multicolumn{1}{|c|}{ TABLE A-18 } \\
\multicolumn{1}{|c|}{ MIT 3115} \\
DECONTAMINATION, FIXATION, PREPARATION FOR REMOVAL, REMOVAL \\
AND NDA OF BLDG. 7 GLOVE BOXES
\end{tabular}


TABLE A-19

MIT 3116

DECON, FINAL SURVEY AND RELEASE OF ADVANCED FUELS LAB - BLDG. 8

\begin{tabular}{|c|c|}
\hline & Title \\
\hline \multicolumn{2}{|l|}{ PROCEDURE } \\
\hline PFDL-AP-0601 & Classification and Certification of Non-transuranic Waste \\
\hline PFDL-0P-D-0834 & $\begin{array}{l}\text { Monitoring Requirements for the Walls, Ceiling and Floor } \\
\text { Surfaces of the Plutonium Laboratories for Radioactive } \\
\text { Contamination }\end{array}$ \\
\hline PFDL -0P- - i-0835 & $\begin{array}{l}\text { Establishment of Surface Grid for Walls, Floors and } \\
\text { Ceilings for Detailed Radiological Survey }\end{array}$ \\
\hline PFDL -OP - D-0837 & \\
\hline PFDL-OP-D-084 1 & $\begin{array}{l}\text { Preliminary Survey Monitoring Requirements for Determining } \\
\text { Radioactive Contamination and Hot Spots on the Wa } 11, \\
\text { Ceiling and Floor Surfaces of Plutonium Laboratories }\end{array}$ \\
\hline PFDL-0P-D-0842 & $\begin{array}{l}\text { Hole Survey Monitoring Requirements for Determining Radio- } \\
\text { active Contamination in Wall, Floor, or Ceiling Penetrations }\end{array}$ \\
\hline PS- 320576-7 & Coating Removal in WARD Lab, Bldg. 7, Cheswick Site \\
\hline PS- 320576-8 & Coating Removal in WARD Lab, Bldg. 8, Cheswick Site \\
\hline ANS I $-\mathrm{N}-13.12$ & $\begin{array}{l}\text { Draft Control of Radioactive Surface Contamination on } \\
\text { Materials, Equipment and Facilities to be Released for } \\
\text { Uncontrolied Use. }\end{array}$ \\
\hline QIP-1101 & Processing Document Review \\
\hline DATA FORMS & \\
\hline PFDL Form 098 & $\begin{array}{l}\text { Facility Release Survey - Smear Identification and Survey } \\
\text { Data }\end{array}$ \\
\hline PFDL Form 099 & Facility Release Survey - Smear Counting Data \\
\hline
\end{tabular}


TABLE $A-20$

MIT 3117

DECON, FINAL SURVEY AND RELEASE OF ARD PLUTONIUM LAB - BLDG. 7

PROCEDURE

PFDL-AP-0601

PFDL - OP - D-0831

Classification and Certification of Non-transuranic Waste

Title

PFDL-OP-D-0834

PFDL-OP-D-0835

PFDL-OP -D-0842

PFDL-OP-D-0846

Repair of Galvanized Drums

Monitoring Requirements for the Walls, Ceiling and Floor Surfaces of the Plutonium Laboratories for Radioactive Contamination

Establishment of Surface Grid for Walls, Floors and Ceilings for Detailed Radiological Survey

Hole Survey Monitoring Requirements for Determining Radioactive Contamination in Wall, Floor, or Ceiling Penetrations

Removal of Contaminated Glove Box Ventilation Duct ARD Building 7

ANSI $-\mathrm{N}-13.12$

Draft - Control of Radioactive Surface Contamination on Materials, Equipment and Facilities to be Released for Uncontrolled Use.

QIP-1101

Processing Document Review

DATA FORMS

PFDL Form 097

Equipment Disposition Record (Potential Plutonium Contamination)

PFDL Form 098

Facility Release Survey - Smear Identification and Survey Data

PFDL Form 099

Facility Release Survey - Smear Counting Data

PFDL Form 101

Total Contamination in Hole Measurements - Facility Release Survey

PFDL Form 102

Hole Surface Smear Counting Data - Facility Release Survey 


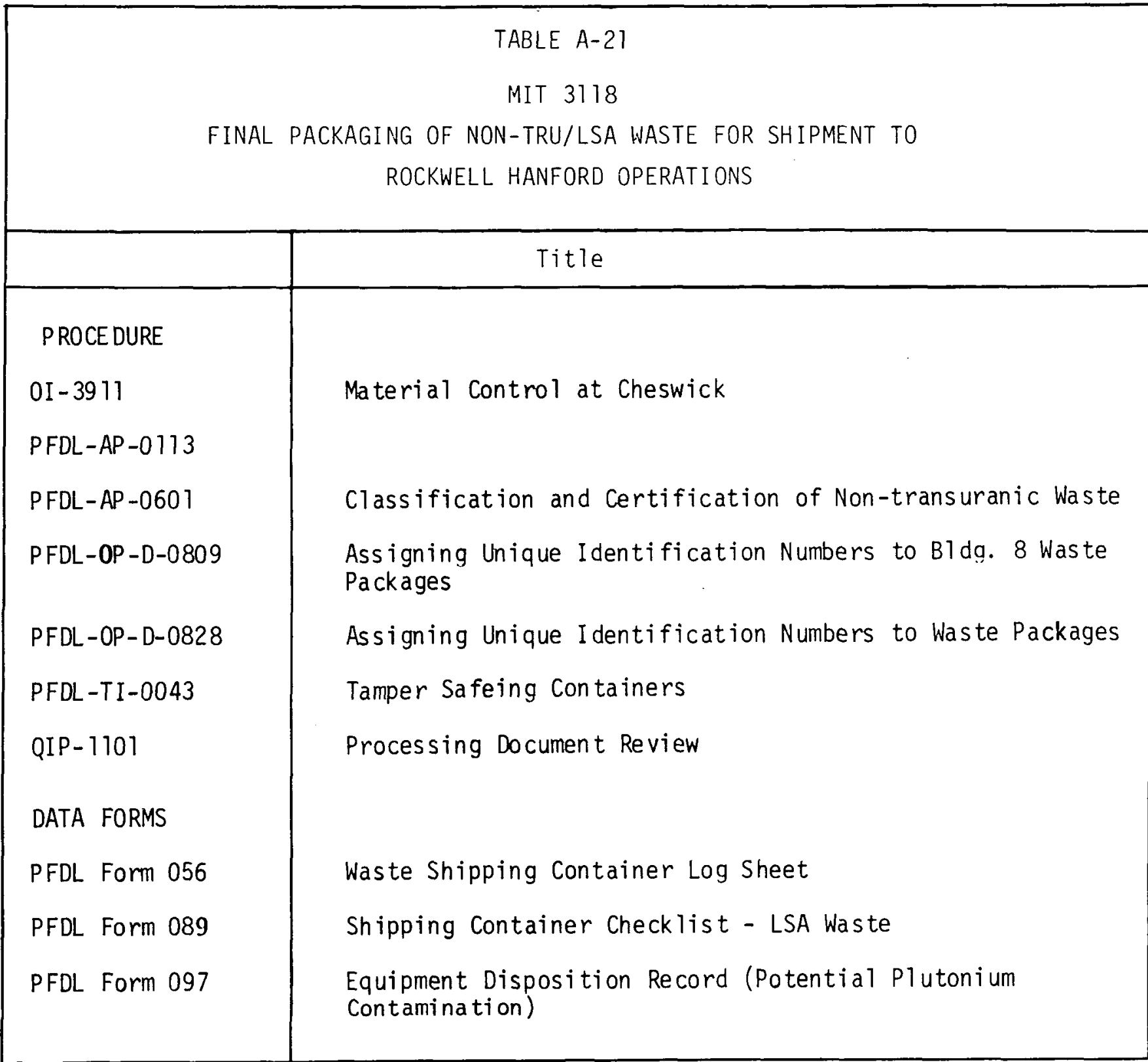


TABLE A-22

MIT 3119

DECON, FINAL SURVEY AND RELEASE OF ARD AIR LOCKS AND SHOWER ROOM

\begin{tabular}{|c|c|}
\hline & Title \\
\hline \multicolumn{2}{|l|}{ PROCEDURE } \\
\hline PFDL-AP-060 1 & Classification and Certification of Non-transuranic Waste \\
\hline PFDL-OP-D-0834 & $\begin{array}{l}\text { Monitoring Requirements for the Walls, Ceiling and Floor } \\
\text { Surfaces of the Plutonium Laboratories for Radioactive } \\
\text { Contamination }\end{array}$ \\
\hline PFDL-OP-D-0835 & $\begin{array}{l}\text { Establishment of Surface Grid for Walls, Floors and } \\
\text { Ceilings for Detailed Radiological Survey }\end{array}$ \\
\hline PFDL-OP-D-0842 & $\begin{array}{l}\text { Hole Survey Monitoring Requirements for Determining } \\
\text { Radioactive Contamination and Hop Spots on the Wall, } \\
\text { Ceiling and Floor Surfaces of Plutonium Laboratories }\end{array}$ \\
\hline ANSI $-N-13.12$ & $\begin{array}{l}\text { Draft - Control of Radioactive Surface Contamination on } \\
\text { Materials, Equipment and Facilities to be Released for } \\
\text { Uncontrolled Use. }\end{array}$ \\
\hline PS $-320576-7$ & Coating Removal in WARD Lab, Bldg. 7, Cheswick Site \\
\hline PS- 320576-8 & Coating Removal in WARD Lab, Bldg. 7, Cheswick Site \\
\hline QIP-1101 & Processing Document Review \\
\hline \multicolumn{2}{|l|}{ DATA FORMS } \\
\hline PFDL Form 097 & $\begin{array}{l}\text { Equipment Disposition Record (Potential Plutonium } \\
\text { Contamination) }\end{array}$ \\
\hline PFDL Form 098 & $\begin{array}{l}\text { Facility Release Survey - Smear Identification and } \\
\text { Survey Data }\end{array}$ \\
\hline PFDL Form 099 & Facility Release Survey - Smear Counting Data \\
\hline PFDL Form 101 & $\begin{array}{l}\text { Total Contamination in Hole Measurements - Facility } \\
\text { Release Survey }\end{array}$ \\
\hline PFDL Form 102 & $\begin{array}{l}\text { Hole Surface Smear Counting Data - Facility Release } \\
\text { Survey }\end{array}$ \\
\hline
\end{tabular}




\begin{tabular}{|c|c|}
\hline & $\begin{array}{c}\text { TABLE A-23 } \\
\text { SMIT } 86 \\
\text {, SEGREGATION, IDENTIF ICAT ION, NDA AND } \\
\text { RY STORAGE OF PREVIOUSLY PACKAGED WASTE }\end{array}$ \\
\hline PROCEDURE/FORM & Title \\
\hline $\begin{array}{l}\text { PFDL-OP-D-0812 } \\
\text { PFDL-OP-0003 }\end{array}$ & $\begin{array}{l}\text { Segregation \& Repackaging Drummed Waste } \\
\text { Treatment, Collection \& Segregation of Wastes for } \\
\text { Disposal }\end{array}$ \\
\hline $\begin{array}{l}\text { ARD-Pu Lab } \\
\text { OP- } 11-800\end{array}$ & $\begin{array}{l}\text { General Operating Procedure for the ARD Advanced Fuel } \\
\text { Laboratory }\end{array}$ \\
\hline PFDL-AL-0023 & $\begin{array}{l}\text { Determination of Plutonium/Uranium in Low Level Waste } \\
\text { by Gamma Spectrometry }\end{array}$ \\
\hline PFDL-TI-0043 & Tamper Safeing Containers \\
\hline QIP-DQA-E-1101 & Processing Document Review \\
\hline OI-3911 & Material Control at ARD Cheswick \\
\hline
\end{tabular}


APPENDIX B

MANUFACTURING AND INSPECTION

TRAVELERS (MITS)

B-1 


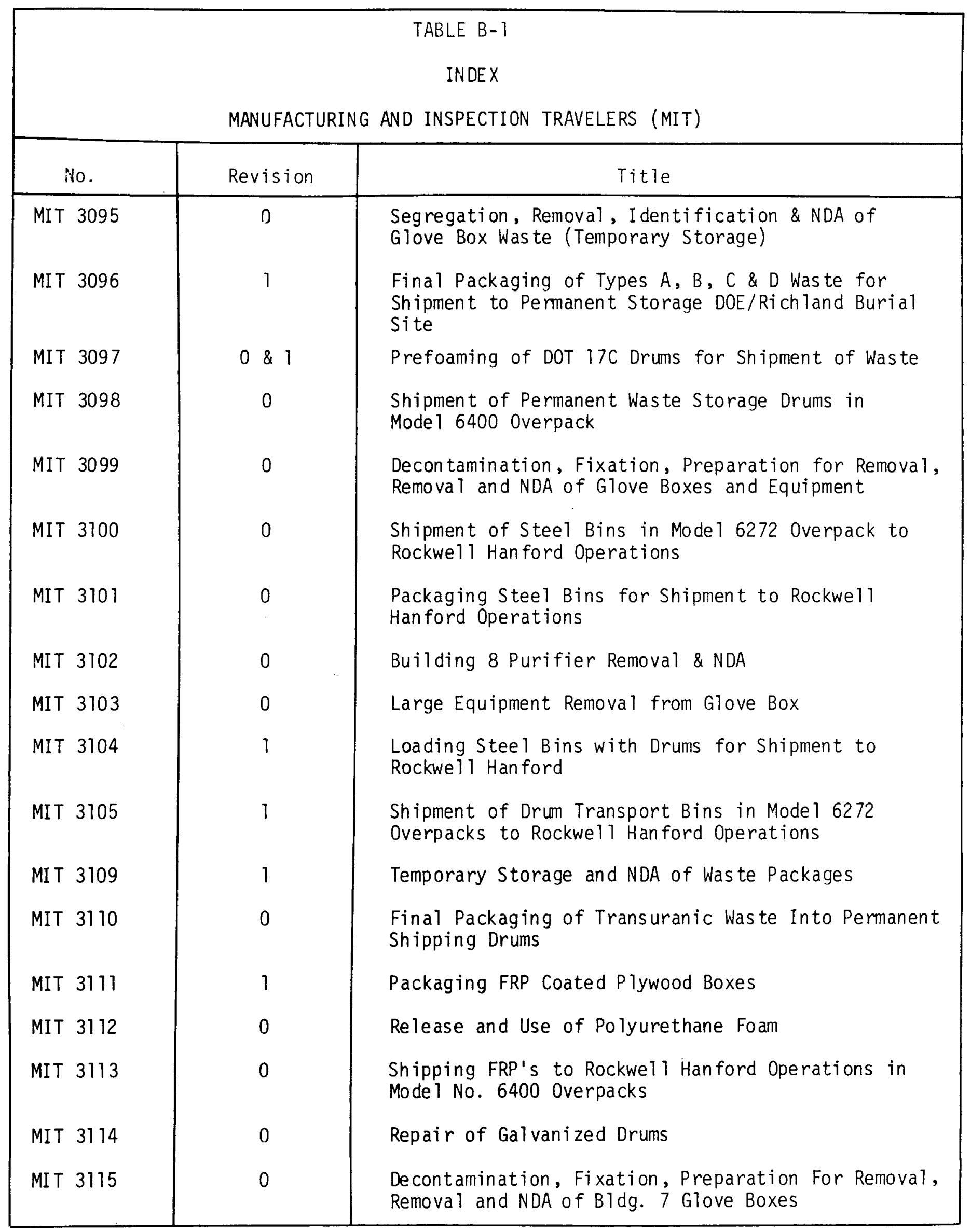




\begin{tabular}{|c|c|c|}
\hline \multicolumn{3}{|c|}{$\begin{array}{c}\text { TABLE B-1 (Cont inued) } \\
\text { INDEX } \\
\text { MANUFACTURING AND INSPECTION TRAVELERS (MIT) }\end{array}$} \\
\hline No. & Revision & Title \\
\hline MIT 3116 & 0 & $\begin{array}{l}\text { Decon, Final Survey and Release of Advanced } \\
\text { Fuels Lab, Bldg. } 8\end{array}$ \\
\hline MIT 3117 & 0 & $\begin{array}{l}\text { Decon, Final Survey and Release of ARD } \\
\text { Plutonium Lab - B1dg. } 7\end{array}$ \\
\hline MIT 3118 & 0 & $\begin{array}{l}\text { Final Packaging of Non-TRU/LSA Waste for } \\
\text { Shipment to Rockwell Hanford Operations }\end{array}$ \\
\hline MIT 3119 & 0 & $\begin{array}{l}\text { Decon, Final Survey and Release of ARD } \\
\text { Air Locks and Shower Room }\end{array}$ \\
\hline SMIT 86 & 0 & $\begin{array}{l}\text { Removal, Segregation, Identification, NDA } \\
\text { and Temporary Storage of Previously Packaged } \\
\text { Was te }\end{array}$ \\
\hline
\end{tabular}


TABLE B-I (Continued)

PROCESS AND INSPECTION DATA SHEETS (PIDS)

\begin{tabular}{|c|c|c|}
\hline No. & Revision & Title \\
\hline PIDS 3095 & 0 & $\begin{array}{l}\text { Segregation, Removal, Identification \& NDA of Glove } \\
\text { Box Waste (Temporary Storage) }\end{array}$ \\
\hline PIDS 3096 & 0 & $\begin{array}{l}\text { Final Packaging of Types } A, B, C \& \text { D Waste for } \\
\text { Shipment to Permanent Storage DOE/Richland Burial } \\
\text { Site }\end{array}$ \\
\hline PIDS 3097 & 0 & Prefoaming of DOT $17 \mathrm{C}$ Drums for Shipment of Was te \\
\hline PIDS 3098 & 0 & $\begin{array}{l}\text { Shipment of Permanent Storage Drums in Mode } 1 \\
\text { No. } 6400 \text { Overpack }\end{array}$ \\
\hline PIDS 3100 & 0 & $\begin{array}{l}\text { Shipment of Stee } 1 \text { Bins in Mode } 16272 \text { Overpack to } \\
\text { Rockwe } 11 \text { Hanford Operations }\end{array}$ \\
\hline PIDS 3103 & 0 & Large Equipment Removal from Glove Box \\
\hline PIDS SMIT-86 & 0 & $\begin{array}{l}\text { Removal, Segregation, Identification, NDA and Tempor- } \\
\text { ary Storage of Previously Packaged Waste }\end{array}$ \\
\hline PIDS 3110 & 0 & $\begin{array}{l}\text { Final Packaging of Transuranic Waste Into Permanent } \\
\text { Shipping Drums }\end{array}$ \\
\hline PIDS 3112 & 0 & Release and Use of Polyurethane Foam \\
\hline PIDS 3114 & 0 & Repair of Galvanized Drums \\
\hline & & PFDL FORMS \\
\hline PFDL Form 008 & 4 & Radioactive Shipment Container Checklist \\
\hline PFDL Form 045 & 5 & Radioactive Shipment Record \\
\hline PFDL Form 056 & 7 & Waste Shipping Container Log Sheet \\
\hline PFDL Form 084 & 6 & $\begin{array}{l}\text { D0T } 17 \mathrm{H} \text { and } 17 \mathrm{C} \text { Shipping Container Checklist - } \\
\text { Transuranics }\end{array}$ \\
\hline PFDL Form 089 & 1 & Shipping Container Checklist - LSA Waste \\
\hline PFDL Form 091 & 1 & Radioactive Shipment Record \\
\hline PFDL Form 092 & 0 & $\begin{array}{l}\text { Radioactive Shipment Record - Instructions to } \\
\text { Carrier for Exclusive Use }\end{array}$ \\
\hline PFDL Form 093 & 3 & M-III Bin Shipping Container Checklist \\
\hline
\end{tabular}


TABLE B-1 (Continued)

PFDL FORMS (cont'd)

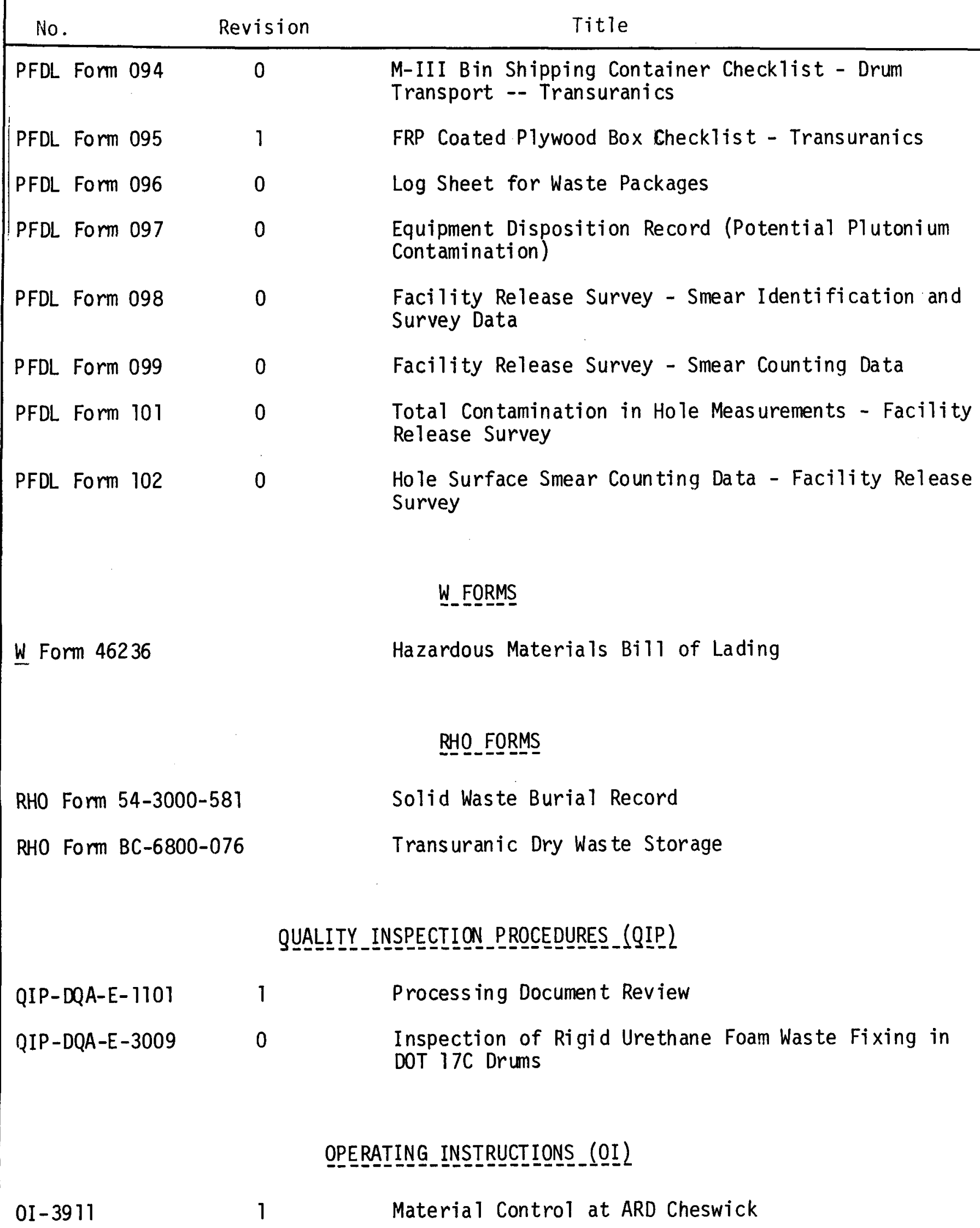




\section{TABLE B-I (Continued)}

PFDL OPERATING PROCEDURES (PFDL-OP)

\begin{tabular}{|c|c|c|}
\hline No. & Revision & Title \\
\hline PFDL-0P-0003 & 20 & $\begin{array}{l}\text { Treatment, Collection, and Segregation of Wastes } \\
\text { for Disposal }\end{array}$ \\
\hline PFDL-0P-0200 & 8 & $\begin{array}{l}\text { Packaging and Labeling Requirements for Radio- } \\
\text { active Material Shipment }\end{array}$ \\
\hline PFDL-0P-0201 & 11 & Shipment of Radioactive Materials \\
\hline PFDL-0P-0216 & 0 & $\begin{array}{l}\text { Radioactive Material Transportation Notification } \\
\text { Requirements }\end{array}$ \\
\hline PFDL-OP-0217 & 1 & $\begin{array}{l}\text { Packaging, Labeling, and Marking Requirements for } \\
\text { Low-Level Waste Shipments Transported in the Mode } 1 \\
6400 \text { Overpack to the Rockwel1 Hanford Operations }\end{array}$ \\
\hline PFDL-0P-0218 & 2 & $\begin{array}{l}\text { Packaging, Labeling, and Marking Requirements for } \\
\text { Low-Level Waste Shipments Transported in the Model } \\
6272 \text { Overpack to the Rockwel1 Hanford Operations }\end{array}$ \\
\hline PFDL-0P-0809 & 1 & $\begin{array}{l}\text { Assigning Unique Identification Numbers to Bldg. } 8 \\
\text { Waste Packages }\end{array}$ \\
\hline PFDL-OP-D-0811 & 2 & Prefoaming of DOT 17C Drums for Shipment of Waste \\
\hline PFDL-OP-D-0812 & 0 & Segregation \& Repackaging Drummed Waste \\
\hline PFDL-OP-D-0813 & 0 & Removal of Large Equipment from Glove Boxes \\
\hline PFDL-0P-D-0815 & 0 & Decontamination and Fixation of Glove Boxes \\
\hline PFDL-OP-D-0816 & 4 & $\begin{array}{l}\text { Packaging of Waste Containers of Shipment to the } \\
\text { Rockwell Hanford Operations Site }\end{array}$ \\
\hline PFDL-0P-D-0817 & 0 & Removal of Potentially Contaminated Hardware \\
\hline PFDL-OP-D-0819 & 1 & Disposal of Plutonium Contaminated Liquid Organics \\
\hline PFDL-0P-D-0826 & 1 & $\begin{array}{l}\text { Separation and Removal of ARD Glove Boxes and } \\
\text { Equipment in Bldg. } 7\end{array}$ \\
\hline PFDL-0P-D-0828 & 0 & $\begin{array}{l}\text { Assigning Unique Identification Numbers to Waste } \\
\text { Packages }\end{array}$ \\
\hline PFDL-OP-D-0829 & 1 & $\begin{array}{l}\text { Transfer of Contaminated Equipment Between } \\
\text { Buildings } 7 \text { and } 8\end{array}$ \\
\hline PFDL-0P-D-0830 & 1 & Packaging FRP Coated Plywood Bores \\
\hline$P F D L-0 P-D-0831$ & 0 & Repair of Galvanized Drums \\
\hline PFDL-OP-D-0833 & 0 & $\begin{array}{l}\text { Application of Fiberglass Seal to FRP Coated } \\
\text { Plywood Boxes }\end{array}$ \\
\hline
\end{tabular}


TABLE B-1 (Continued)

PFDL TECHNICAL INSTRUCTIONS (PFDL-TI)

No.

PFDL-TI -0043

Revision

9

Title

PEDL_ANALYII CALL_LAB PROCEDURES (PFDL-AL)

PFDL-AL-0023 $8 \quad$ Determination of Pu/U in Low-Level Waste by Gamma Spectrometry

PFDL -AL-0057

Assay of SNM Holdup in Glove Boxes by Gamma Spectrometry

USNRC_CERTIFICATES OF COMPLIANCE

USNRC 6272

Certificate of Compliance for Model 6272 (Poly Panther) Overpack

USNRC 6400 , dated $1 / 26 / 81$

Exemption Letter for Model 6400 (Super Tiger) Overpack

\section{ARD/PFDL = SPECIAL PROCEDURES}

ARD-PFDL-SP-06-10-80

ARD Pu Lab OP $-11-700$

3

Disconnection \& Removal of Purifiers

General Operating Procedure for ARD Plutonium Laboratory

ARD Pu Lab OP-11-800 5

General Operating Procedure for the ARD Advanced Fue 1 Laboratory

\section{OUTSIDE_CONTRACTOR'S PROCEDURES}

PS $3205676-7$

Coating Removal in WARD Lab, B1dg. 7, Cheswick Site

PS $320576-8$ 